\title{
Water Sorption and Gamma Radiolysis Studies for Uranium Oxides
}

February 2002

\author{
A. S. Icenhour \\ L. M. Toth \\ H. Luo
}


This report has been reproduced from the best available copy.

Reports are available to the public from the following source.

National Technical Information Service

5285 Port Royal Road

Springfield, VA 22161

Telephone 703-605-6000 (1-800-553-6847)

TDD 703-487-4639

Fax703-605-6900

E-mail orders@ntis.fedworld.gov

Web site http://www.ntis.gov/ordering.htm

Reports are available to U.S. Department of Energy (DOE) employees, DOE contractors, Energy Technology Data Exchange (ETDE) representatives, and International Nuclear Information System (INIS) representatives from the following source.

Office of Scientific and Technical Information

P.O. Box 62

Oak Ridge, TN 37831

Telephone 865-576-8401

Fax 865-576-5728

E-mail reports@adonis.osti.gov

Web site http://www.osti.gov/products/sources.html

Reports produced after January 1, 1996, are generally available via the DOE Information Bridge.

Web site http://www.doe.gov/bridge

This report was prepared as an account of work sponsored by an agency of the United States government. Neither the United States government nor any agency thereof, nor any of their employees, makes any warranty, express or implied, or assumes any legal liability or responsibility for the accuracy, completeness, or usefulness of any information, apparatus, product, or process disclosed, or represents that its use would not infringe privately owned rights. Reference herein to any specific commercial product, process, or service by trade name, trademark, manufacturer, or otherwise, does not necessarily constitute or imply its endorsement, recommendation, or favoring by the United States government or any agency thereof. The views and opinions of authors expressed herein do not necessarily state or reflect those of the United States government or any agency thereof. 
ORNL/TM-2001/59

Nuclear Science And Technology Division

\title{
WATER SORPTION AND GAMMA RADIOLYSIS STUDIES FOR URANIUM OXIDES
}

\author{
A. S. Icenhour \\ L. M. Toth \\ H. Luo
}

Date Published: February 2002

Prepared by

OAK RIDGE NATIONAL LABORATORY

P.O. Box 2008

Oak Ridge, Tennessee 37831-6285

managed by

UT-Battelle, LLC

for the

U.S. DEPARTMENT OF ENERGY

under contract DE-AC05-00OR22725 



\section{CONTENTS}

Page

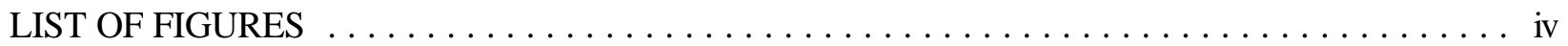

LIST OF TABLES $\ldots \ldots \ldots \ldots \ldots \ldots \ldots \ldots \ldots \ldots \ldots \ldots \ldots \ldots \ldots \ldots$

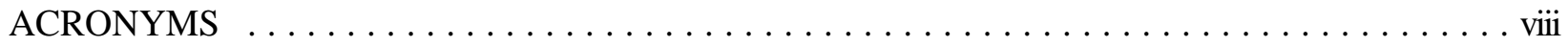

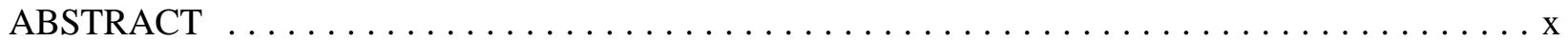

1. INTRODUCTION $\ldots \ldots \ldots \ldots \ldots \ldots \ldots \ldots \ldots \ldots \ldots \ldots \ldots \ldots \ldots \ldots \ldots$

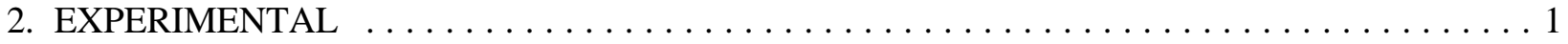

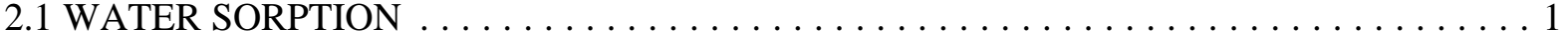

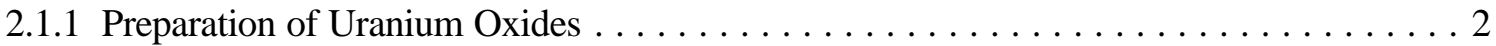

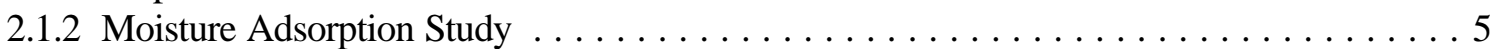

2.2 GAMMA RADIOLYSIS EXPERIMENTS $\ldots \ldots \ldots \ldots \ldots \ldots \ldots \ldots \ldots \ldots$

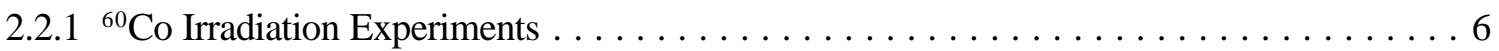

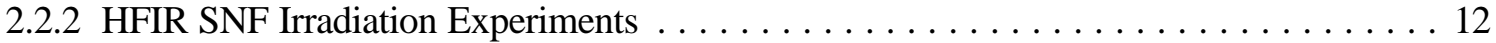

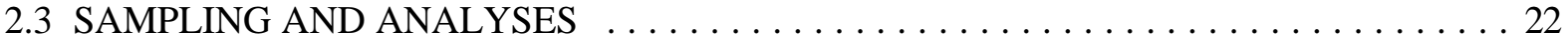

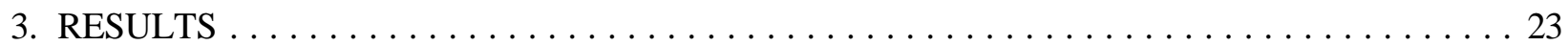

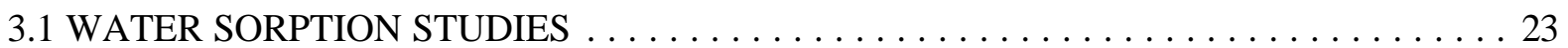

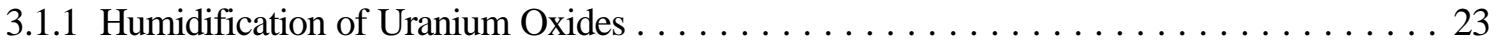

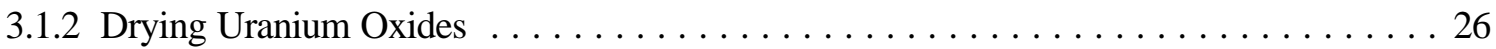

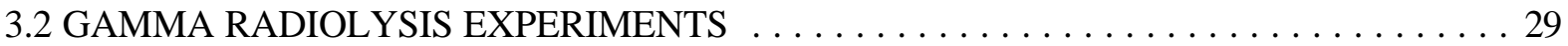

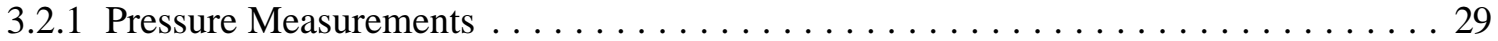

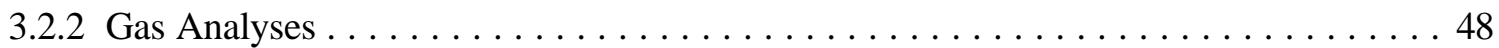

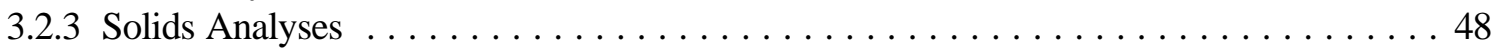

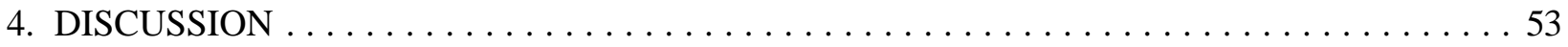

4.1 WATER SORPTION AND DESORPTION $\ldots \ldots \ldots \ldots \ldots \ldots \ldots \ldots \ldots \ldots \ldots \ldots$

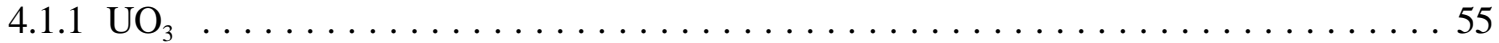

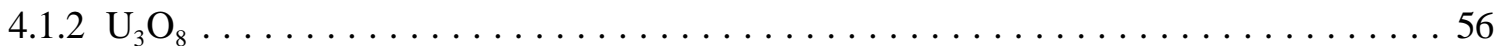

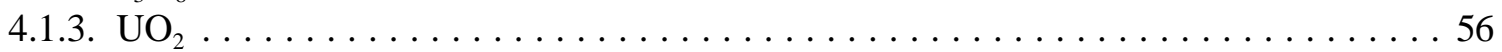

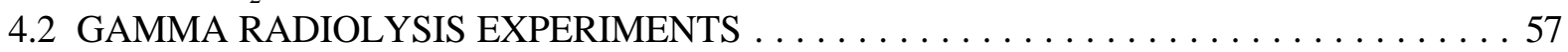

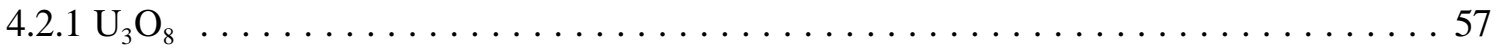

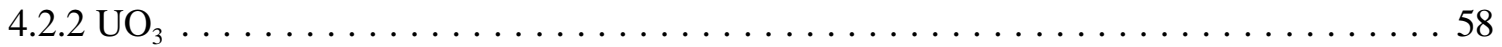

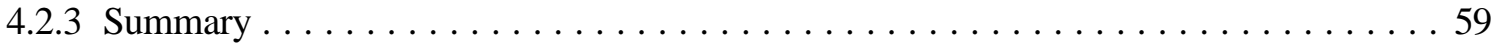

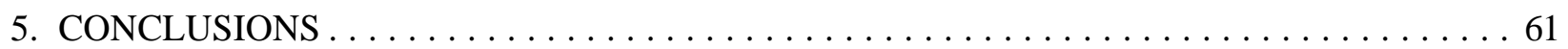

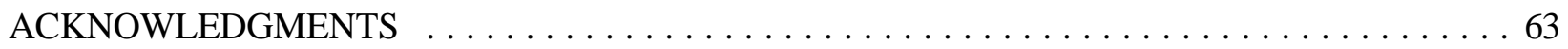

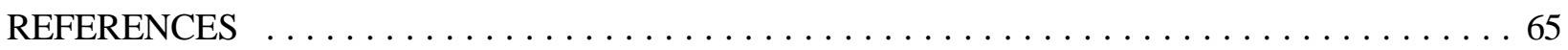

Appendix A: ESTIMATION OF ABSORBED DOSE FROM EXPOSURE $\ldots \ldots \ldots \ldots \ldots \ldots$ 



\section{LIST OF FIGURES}

Figure

Page

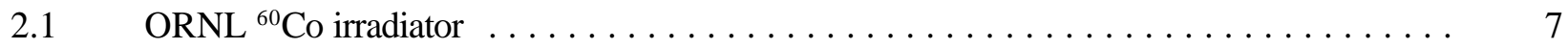

2.2 Irradiation chamber of ORNL ${ }^{60}$ Co irradiator with sample containers installed . . . . . 7

2.3 Exposure-rate profile for $\mathrm{ORNL}{ }^{60} \mathrm{Co}$ irradiation chamber $\ldots \ldots \ldots \ldots \ldots$

2.4 Sample container and pressure transducer used in the ${ }^{60} \mathrm{Co}$ irradiations $\ldots \ldots \ldots \ldots$

2.5 Data acquisition computer in operation at the $\mathrm{ORNL}{ }^{60} \mathrm{Co}$ source $\ldots \ldots \ldots \ldots \ldots$

2.6 SNF elements in the HFIR SNF pool $\ldots \ldots \ldots \ldots \ldots \ldots \ldots \ldots \ldots \ldots \ldots \ldots$

2.7 Peak exposure rate in a HFIR SNF element as a function of time since reactor

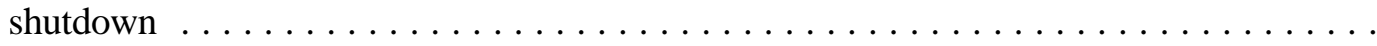

2.8 Ratio of exposure rate to the peak exposure rate as a function of axial position in

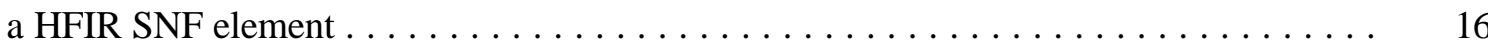

2.9 Schematic of nickel container used in the HFIR SNF small-vessel irradiations $\ldots \ldots \ldots$

2.10 Schematic of the experimental configuration for gamma irradiation experiments

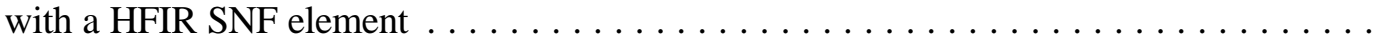

$2.11 \quad$ Multiple-irradiation container used in HFIR SNF irradiations $\ldots \ldots \ldots \ldots \ldots \ldots \ldots$

2.12 Pressure transducer assembly that was connected to the multiple-irradiation container and used in HFIR SNF irradiations $\ldots \ldots \ldots \ldots \ldots \ldots \ldots \ldots \ldots \ldots \ldots$

2.13 Schematic of sampling rig used to withdraw gas samples from an irradiation

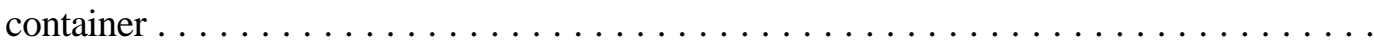

$3.1 \quad$ Weight gain for $\mathrm{UO}_{3}$ in $97.5 \%$ relative humidity $\ldots \ldots \ldots \ldots \ldots \ldots \ldots \ldots \ldots \ldots \ldots \ldots$

3.2 Weight gain for $\mathrm{UO}_{3}$ in 70 and $97.5 \%$ relative humidities $\ldots \ldots \ldots \ldots \ldots \ldots$

3.3 Weight gain for $\mathrm{U}_{3} \mathrm{O}_{8}$ in 70 and $97.5 \%$ relative humidities $\ldots \ldots \ldots \ldots \ldots \ldots$

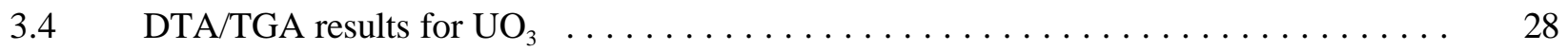

3.5 Weight loss for $\mathrm{U}_{3} \mathrm{O}_{8}$ on heating at a fixed temperature of $150^{\circ} \mathrm{C} \ldots \ldots \ldots \ldots$

3.6 DTA/TGA of moisture-saturated $\mathrm{U}_{3} \mathrm{O}_{8}$ in $\operatorname{argon} \ldots \ldots \ldots \ldots \ldots \ldots \ldots \ldots \ldots \ldots$

3.7 Pressure and gas yield as a function of dose for sample S-15 $\left({ }^{60} \mathrm{Co}\right.$-irradiated

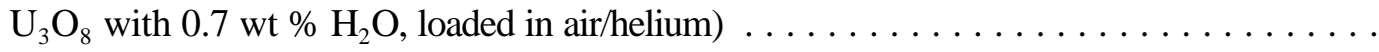


LIST OF FIGURES (continued)

3.8 Pressure and gas yield as a function of dose for sample $\mathrm{S}-17\left({ }^{60} \mathrm{Co}\right.$-irradiated

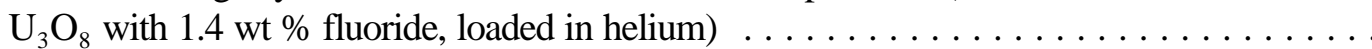

3.9 Pressure and gas yield as a function of dose for sample S-19 $\left({ }^{60} \mathrm{Co}\right.$-irradiated

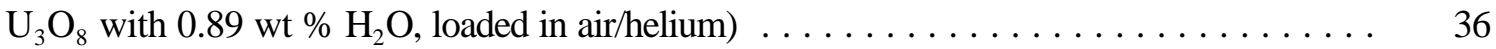

3.10 Pressure and gas yield as a function of dose for sample HFIR-2 (HFIR

SNF-irradiated $\mathrm{U}_{3} \mathrm{O}_{8}$ with $1.4 \mathrm{wt} \%$ fluoride, loaded in helium) $\ldots \ldots \ldots \ldots \ldots$

3.11 Pressure and gas yield as a function of dose for sample HFIR-3 (HFIR

SNF-irradiated $\mathrm{U}_{3} \mathrm{O}_{8}$ with $1.4 \mathrm{wt} \%$ fluoride and $9.1 \mathrm{wt} \% \mathrm{H}_{2} \mathrm{O}$, loaded in

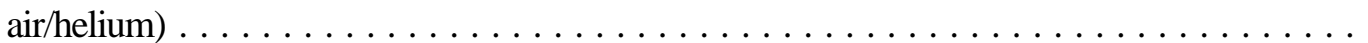

3.12 Pressure and gas yield as a function of dose for sample HFIR-5 (HFIR

SNF-irradiated $\mathrm{U}_{3} \mathrm{O}_{8}$ with 1.04 wt $\% \mathrm{H}_{2} \mathrm{O}$, loaded in air/helium) $\ldots \ldots \ldots \ldots \ldots$

3.13 Pressure and gas yield as a function of dose for sample HFIR-6-1 (HFIR

SNF-irradiated $\mathrm{U}_{3} \mathrm{O}_{8}$ with $5 \mathrm{wt} \% \mathrm{Gd}_{2} \mathrm{O}_{3}$ and $1.48 \mathrm{wt} \% \mathrm{H}_{2} \mathrm{O}$, loaded in air) $\ldots \ldots \ldots$

3.14 Pressure and gas yield as a function of dose for sample HFIR-6-2 (HFIR

SNF-irradiated $\mathrm{U}_{3} \mathrm{O}_{8}$ with 6 wt $\% \mathrm{H}_{2} \mathrm{O}$, loaded in air) $\ldots \ldots \ldots \ldots \ldots \ldots \ldots \ldots \ldots \ldots \ldots$

3.15 Pressure and gas yield as a function of dose for sample S-14 $\left({ }^{60} \mathrm{Co}\right.$-irradiated

$\mathrm{UO}_{3} \mathrm{GH}_{2} \mathrm{O}$ with 1.8 wt $\% \mathrm{H}_{2} \mathrm{O}$, loaded in air/helium) $\ldots \ldots \ldots \ldots \ldots \ldots \ldots \ldots$

3.16 Pressure and gas yield as a function of dose for sample $\mathrm{S}-18\left({ }^{60} \mathrm{Co}\right.$-irradiated

$\mathrm{UO}_{3} \mathrm{CH}_{2} \mathrm{O}$ with $2.47 \mathrm{wt} \%$ sorbed $\mathrm{H}_{2} \mathrm{O}$, loaded in air/helium) $\ldots \ldots \ldots \ldots \ldots \ldots$

3.17 Pressure and gas yield as a function of dose for sample HFIR-4 (HFIR

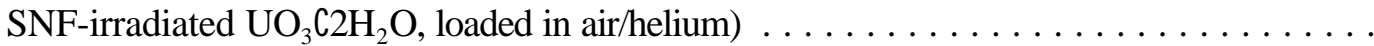

3.18 Pressure and gas yield as a function of dose for sample HFIR-6-3 (HFIR

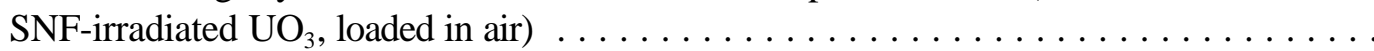

3.19 Estimated temperature as a function of time for vessels HFIR-6-1,

HFIR-6-2, and HFIR-6-3 . . . . . . . . . . . . . . . . . . . . .

3.20 Pressure as a function of time for samples HFIR-6-1, HFIR-6-2, and

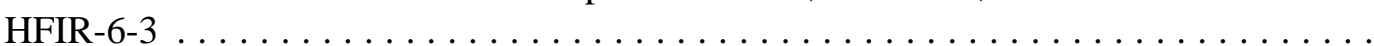

A.1 Exposure-rate-curve fit for HFIR SNF element from cycle $371 \ldots \ldots \ldots \ldots \ldots \ldots$ 


\section{LIST OF TABLES}

Table

Page

2.1 Summary of $\mathrm{UO}_{\mathrm{x}}$ preparations $\ldots \ldots \ldots \ldots \ldots \ldots \ldots \ldots \ldots \ldots \ldots \ldots$

2.2 Constant humidity with sulfuric acid solutions $\ldots \ldots \ldots \ldots \ldots \ldots \ldots \ldots \ldots$

2.3 Volume measurements of irradiation containers as determined by gas expansion method $\ldots \ldots \ldots \ldots \ldots \ldots \ldots \ldots \ldots \ldots \ldots \ldots \ldots \ldots \ldots \ldots \ldots$

2.4 Gamma-ray energy spectrum for a HFIR SNF element $1 \mathrm{~d}$ after

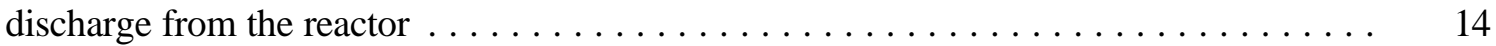

$3.1 \quad$ Humidification/Drying tests of uranium oxides $\ldots \ldots \ldots \ldots \ldots \ldots \ldots \ldots \ldots \ldots$

3.2 Summary of irradiation experiments performed $\ldots \ldots \ldots \ldots \ldots \ldots \ldots \ldots$

3.3 Results of mass spectrometric analysis (vol \%) of gas composition from $\mathrm{U}_{3} \mathrm{O}_{8}$ samples irradiated in either the ${ }^{60} \mathrm{Co}$ source or HFIR SNF elements $\ldots \ldots \ldots \ldots \ldots \ldots$

3.4 Results of mass spectrometric analysis (vol \%) of gas composition from $\mathrm{UO}_{3} \mathrm{CxH}_{2} \mathrm{O}$ samples irradiated in either the ${ }^{60} \mathrm{Co}$ source or HFIR SNF elements $\ldots \ldots$.

3.5 Comparison of gas composition (relative to argon) for a standard air

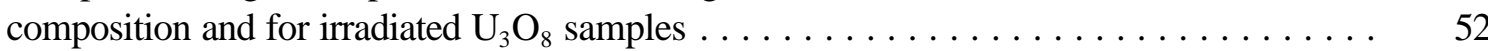

3.6 Comparison of gas composition (relative to argon) for a standard air composition and for irradiated $\mathrm{UO}_{3} \mathrm{GH}_{2} \mathrm{O}$ samples $\ldots \ldots \ldots \ldots \ldots \ldots \ldots \ldots \ldots \ldots$

Results of analysis of samples for $\mathrm{U}(\mathrm{IV})$ content $\ldots \ldots \ldots \ldots \ldots \ldots \ldots \ldots$

4.1 Summary of $\mathrm{H}_{2}$ yields for gamma radiolysis experiments with

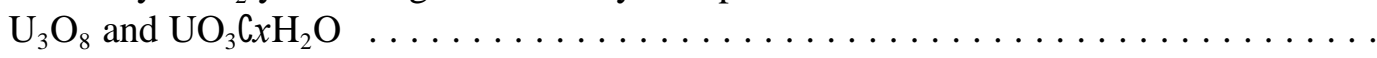

A.1 Selected mass energy absorption coefficients $\ldots \ldots \ldots \ldots \ldots \ldots \ldots \ldots \ldots \ldots$

A.2 Selected attenuation coefficients $(\mu)$ for materials used in irradiation containers . . . . . 69 



\section{ACRONYMS}

$\begin{array}{ll}\text { ASTM } & \text { American Society for Testing and Materials } \\ \text { BET } & \text { Branauer, Emmett, Teller } \\ \text { DTA } & \text { Consolidated Edison Uranium Solidification Project } \\ \text { FTIR } & \text { Fourier transform infrared } \\ \text { HFIR } & \text { High Flux Isotope Reactor } \\ \text { MSRE } & \text { Molten Salt Reactor Experiment } \\ \text { ORNL } & \text { Oak Ridge National Laboratory } \\ \text { SNF } & \text { spent nuclear fuel } \\ \text { TGA } & \text { thermogravimetric analysis } \\ \text { UNH } & \text { uranyl nitrate hexahydrate, } \mathrm{UO}_{2}\left(\mathrm{NO}_{3}\right)_{2} \mathrm{CbH}_{2} \mathrm{O} \\ \text { XRD } & \text { X-ray diffraction }\end{array}$





\begin{abstract}
During the development of a standard for the safe, long-term storage of ${ }^{233} \mathrm{U}$-containing materials, several areas were identified that needed additional experimental studies. These studies were related to the perceived potential for the radiolytic generation of large pressures or explosive concentrations of gases in storage containers. This report documents the results of studies on the sorption of water by various uranium oxides and on the gamma radiolysis of uranium oxides containing various amounts of sorbed moisture. In all of the experiments, ${ }^{238} \mathrm{U}$ was used as a surrogate for the ${ }^{233} \mathrm{U}$. For the water sorption experiments, uranium oxide samples were prepared and exposed to known levels of humidity to establish the water uptake rate. Subsequently, the amount of water removed was studied by heating samples in a oven at fixed temperatures and by thermogravimetric analysis (TGA)/differential thermal analysis (DTA). It was demonstrated that heating at 650EC adequately removes all moisture from the samples. Uranium-238 oxides were irradiated in a ${ }^{60} \mathrm{Co}$ source and in the high-gamma-radiation fields provided by spent nuclear fuel elements of the High Flux Isotope Reactor. For hydrated samples of $\mathrm{UO}_{3}$, $\mathrm{H}_{2}$ was the primary gas produced; but the total gas pressure increase reached steady value of about 10 psi. This production appears to be a function of the dose and the amount of water present. Oxygen in the hydrated $\mathrm{UO}_{3}$ sample atmosphere was typically depleted, and no significant pressure rise was observed. Heat treatment of the $\mathrm{UO}_{3} \cdot x \mathrm{H}_{2} \mathrm{O}$ at $650 \mathrm{EC}$ would result in conversion to $\mathrm{U}_{3} \mathrm{O}_{8}$ and eliminate the $\mathrm{H}_{2}$ production. For all of the $\mathrm{U}_{3} \mathrm{O}_{8}$ samples loaded in air and irradiated with gamma radiation, a pressure decrease was seen and little, if any, $\mathrm{H}_{2}$ was produced—even for samples with up to 9 wt $\%$ moisture content. Hence, these results demonstrated that the efforts to remove trace moisture from $\mathrm{U}_{3} \mathrm{O}_{8}$ are not necessary to avoid pressurization of stored uranium oxides caused by gamma-induced radiolysis. In fact, this system can tolerate several percent of sorbed moisture-most of which can be easily removed by heating to only $150 \mathrm{EC}$. To complete the picture of the radiolytic response of uranium oxides that have sorbed moisture, alpha radiolysis experiments have been initiated.
\end{abstract}





\section{INTRODUCTION}

The development of a standard for the safe, long-term storage of ${ }^{233} \mathrm{U}$-containing materials ${ }^{1}$ resulted in the identification of several needed experimental studies. These studies were largely motivated by a perceived potential for the radiolytic generation of unacceptable pressures or deleterious products during the storage of ${ }^{233} \mathrm{U}$ oxides. The primary concern was that these conditions could occur as a result of the direct or indirect radiolysis of residual impurities—-specifically fluorides and water-by the high radiation fields associated with ${ }^{233} \mathrm{U}$-containing materials.

The gamma radiolysis of fluoride impurities in uranium oxides has been studied, and it was demonstrated that such radiolysis will not result in either overpressurization of storage containers or the production of deleterious products. ${ }^{2}$ Since a major concern in the development of the ${ }^{233} \mathrm{U}$ storage standard has involved radiolysis of water that could be associated with the stored oxides, ${ }^{1}$ this report documents the study of the gamma radiolysis of water that is sorbed on uranium oxides and compares these results with those from the radiolysis of dry uranium oxides. Furthermore, this study included experiments on the rate and amount of water uptake by uranium oxides, because it was believed that the major cause of radiolytic pressurization was due to the radiolysis of this water. Such water would sorb principally during the packaging and handling of the oxides in a humid environment. The following sections provide a description of the experiments, experimental results, a discussion of the results, and conclusions.

\section{EXPERIMENTAL}

The experimental program was divided into two distinct activities: water sorption studies and gamma radiolysis experiments.

\subsection{WATER SORPTION}

The water sorption studies involved the preparation of uranium oxides, which was followed by moisture adsorption studies. 


\subsubsection{Preparation of Uranium Oxides}

For this work, it was not practical to use the ${ }^{233} \mathrm{U}$ oxides currently in storage because the high gamma activity associated with the ${ }^{232} \mathrm{U}$ impurity that is present in all of these oxides would complicate their safe handling. Therefore, the irradiation of ${ }^{238} \mathrm{U}$ oxides (as surrogates for ${ }^{233} \mathrm{U}$ oxides) with radiation sources that give equivalent doses, but at higher rates that were more reasonable for the duration of this study, was the most practical way to evaluate the radiolytic effects on these oxides. Even though some ${ }^{238} \mathrm{U}$ oxides from previous research activities were available for the water sorption studies, their pedigree, which included method of preparation, temperature and storage history, was uncertain. To realize such a pedigree, it was necessary to prepare these surrogate uranium oxides (i.e., $\mathrm{UO}_{3}, \mathrm{U}_{3} \mathrm{O}_{8}$, and $\mathrm{UO}_{2}$ ) for this particular task by following procedures most probably* similar to those used in the preparation of the stored ${ }^{233} \mathrm{U}$ oxides. The oxides were prepared by direct thermal denitration at various temperatures to promote formation of the particular uranium oxide compounds. The starting reagent for most of these preparations was uranyl nitrate hexahydrate $(\mathrm{UNH}), \mathrm{UO}_{2}\left(\mathrm{NO}_{3}\right)_{2} \mathrm{CGH}_{2} \mathrm{O}$.

Immediately following the preparations, the anhydrous samples were placed in capped storage vials and then stored in a dessicator with Drierite ${ }^{\circledR}$ to prevent any premature, extended exposure to moisture in the air. While this method did not eliminate the brief air exposure associated with the transfer of the samples from the cooled reaction vessel to the dessicator, the results of the weight-gain measurements and the subsequent radiolysis data demonstrated that this cursory exposure had no measurable influence on the results or the conclusions drawn from these experiments.

\subsubsection{UO}

The $\mathrm{UO}_{3}$ was prepared by simple thermal decomposition of $\mathrm{UNH}$ at $350^{\circ} \mathrm{C}$ according to the following reaction:

$$
\mathrm{UO}_{2}\left(\mathrm{NO}_{3}\right)_{2} 6 \mathrm{CH}_{2} \mathrm{O} \int \mathrm{UO}_{3}+2 \mathrm{NO}_{2}+1 / 2 \mathrm{O}_{2}+6 \mathrm{H}_{2} \mathrm{O} \text {. }
$$

Several batches (5-28 g each) were prepared by placing the weighed amount in an open porcelain dish and heating slowly $\left(\sim 1^{\circ} / \mathrm{min}\right)$ to $350^{\circ} \mathrm{C}$ in a pot furnace. The slow heating was necessary to minimize the sputtering of the material as it thermally decomposed. During this controlled heating, the solid UNH melted/decomposed at $\sim 150^{\circ} \mathrm{C}$, followed by a change in the color of the residue from yellow-green to light orange at $\sim 250^{\circ} \mathrm{C}$. X-ray diffraction (XRD) measurements of the product confirmed that the light orange solid was anhydrous $\mathrm{UO}_{3}$. Branauer, Emmett, Teller (BET) surface area measurements yielded areas of $0.49,0.35$, and $0.55 \mathrm{~m}^{2} / \mathrm{g}$, which were typical of that achieved by this method of preparation.

\footnotetext{
${ }^{*}$ It is not always clear under what conditions these stored oxides were prepared.
} 
2.1.1.2 $\quad \mathrm{U}_{3} \mathrm{O}_{8}$

$\mathrm{U}_{3} \mathrm{O}_{8}$ was most conveniently prepared by further heating of the $\mathrm{UO}_{3}$ product (see Sect. 2.1.1.1) to $650^{\circ} \mathrm{C}$ to effect the following reaction:

$$
3 \mathrm{UO}_{3} \int \mathrm{U}_{3} \mathrm{O}_{8}+1 / 2 \mathrm{O}_{2} \text {. }
$$

As before, small batches (7-12 g) were prepared, this time by heating to $650^{\circ} \mathrm{C}$ at $1-2^{\circ} \mathrm{C} / \mathrm{min}$ in an open porcelain dish and holding at temperature overnight to yield a black solid product. XRD analysis confirmed that the product was $\mathrm{U}_{3} \mathrm{O}_{8}$. The BET surface area of $1.34 \mathrm{~m}^{2} / \mathrm{g}$ was typical for these preparations.

\subsubsection{3 $\mathrm{U}_{3} \mathrm{O}_{8}$ containing $5 \% \mathrm{Gd}_{2} \mathrm{O}_{3}$}

To simulate the composition of Consolidated Edison Uranium Solidification Project (CEUSP)-type materials that contain potentially hygroscopic $\mathrm{Gd}_{2} \mathrm{O}_{3}, \mathrm{U}_{3} \mathrm{O}_{8}$ doped with $\mathrm{Gd}_{2} \mathrm{O}_{3}$ was prepared by combining a solution of $\mathrm{Gd}_{2} \mathrm{O}_{3}$ with that of $\mathrm{UNH}$ and then evaporating the mixture to dryness. The $\mathrm{Gd}_{2} \mathrm{O}_{3}$ solution was prepared by dissolving $0.89 \mathrm{~g} \mathrm{Gd}_{2} \mathrm{O}_{3}$ (Reaction, 99.99\%) in $10 \mathrm{~mL}$ of $6 \mathrm{NHNO}_{3}$ and stirring for 1-2 h to effect complete dissolution. Similarly, $30.2 \mathrm{~g}$ of $\mathrm{UNH}$ was dissolved in $35 \mathrm{~mL}$ of $6 \mathrm{~N} \mathrm{HNO}_{3}$. The two solutions were combined to produce $\sim 60 \mathrm{~mL}$ of a clear yellow solution, which was then evaporated to near dryness by heating to $80^{\circ} \mathrm{C}$. When approximately $50 \%$ of the solution had evaporated, a yellow solid precipitate ( $\mathrm{UNH}$ with $\mathrm{Gd}_{2} \mathrm{O}_{3}$ ) began to appear. By careful control of the drying, most of the liquid was allowed to evaporate, leaving a wet solid that was then transferred to a porcelain dish for further, higher-temperature drying. The dish was placed in a furnace and heated slowly to $340^{\circ} \mathrm{C}$, held overnight at temperature, and then weighed. At this stage, the orange solid (the color typical of anhydrous $\mathrm{UO}_{3}$ ) contained about 5 wt $\% \mathrm{Gd}_{2} \mathrm{O}_{3}$ (yield/expected: 18.4/18.1). The material was returned to the furnace and heated at $650^{\circ} \mathrm{C}$ overnight to produce black $\mathrm{U}_{3} \mathrm{O}_{8}$ according to the reaction in Eq. (2) (yield/expected: 17.96/17.73). The surface area was found to be $1.61 \mathrm{~m}^{2} / \mathrm{g}$ - similar to that of $1.34 \mathrm{~m}^{2} / \mathrm{g}$ obtained for the neat $\mathrm{U}_{3} \mathrm{O}_{8}$ prepared by the method described in Sect. 2.1.1.2.

\subsubsection{4 $\mathrm{UO}_{2}$ using $\mathrm{U}_{3} \mathrm{O}_{8}$ starting material}

Uranium dioxide was prepared by heating $\mathrm{U}_{3} \mathrm{O}_{8}$ in hydrogen at $\sim 900^{\circ} \mathrm{C}$ to effect the following reaction:

$$
\mathrm{U}_{3} \mathrm{O}_{8}+2 \mathrm{H}_{2} \int 3 \mathrm{UO}_{2}+2 \mathrm{H}_{2} \mathrm{O} \text {. }
$$

A 5.4-g portion of the $\mathrm{U}_{3} \mathrm{O}_{8}$ from one of the previous preparations was placed in a porcelain boat which, in turn, was inserted in a silica tube horizontally positioned in a clam-shell furnace. The silica tube was connected at one end to an O-ring joint (for loading access) fitted to an O-ring Pyrex valve to which a 0.635-cm (1/4-in.) Teflon ${ }^{\circledR}$ gas line was attached. The opposite end of the tube had a graded seal to transition from silica to an O-ring Pyrex valve leading to a Teflon exit gas line. A flow of $4 \%$ hydrogen 
in argon was introduced into the system at a flow rate of $100 \mathrm{~mL} / \mathrm{min}$. The furnace was heated to $896^{\circ} \mathrm{C}$ over a period of $5 \mathrm{~h}$ and kept at this temperature for $42 \mathrm{~h}$. A dark brown solid was obtained which XRD analysis demonstrated was $\mathrm{UO}_{2}$ containing a trace of $\mathrm{U}_{4} \mathrm{O}_{9}$ (yield/calculated: 4.92/5.19). (Most of the loss was incurred during the transfer from the porcelain boat to the storage container.) The BET surface area was found to be $0.06 \mathrm{~m}^{2} / \mathrm{g}$ - which is consistent with that expected for material fired in this manner.

\subsubsection{5 $\mathrm{UO}_{2}$ using $\mathrm{UO}_{3}$ reagent}

Elimination of the $\mathrm{U}_{3} \mathrm{O}_{8}$ intermediate allows the production of $\mathrm{UO}_{2}$ directly from the trioxide, $\mathrm{UO}_{3}$, according to

$$
\mathrm{UO}_{3}+\mathrm{H}_{2} \int \mathrm{UO}_{2}+\mathrm{H}_{2} \mathrm{O} \text {. }
$$

A 7.53-g charge of $\mathrm{UO}_{3}$ was loaded in the porcelain boat and placed in the same silica tube within the clam-shell furnace. As before, a $4 \% \mathrm{H}_{2}$ in argon gas stream was passed over the sample at $100 \mathrm{~mL} / \mathrm{min}$. The furnace was heated to $550^{\circ} \mathrm{C}$ over a period of $2 \mathrm{~h}$ and kept at this temperature for $45 \mathrm{~h}$. The product on this occasion was obtained as a black solid which XRD analysis identified as $\mathrm{UO}_{2}$ containing traces of $\mathrm{U}_{4} \mathrm{O}_{9}$ (yield/calculated: 6.92/7.11). This is apparently a better method for preparing $\mathrm{UO}_{2}$ because of the lower reaction temperature and thus reduced tendency toward sintering. The surface area determination of $0.79 \mathrm{~m}^{2} / \mathrm{g}$ is considerably higher than that of $0.06 \mathrm{~m}^{2} / \mathrm{g}$ - confirming the sintering of the material at higher temperatures.

A summary of several preparations is given in Table 2.1.

Table 2.1. Summary of $\mathrm{UO}_{\mathrm{x}}$ preparations

\begin{tabular}{lccc}
\hline & Obtained weight $(\mathrm{g})$ & Calculated weight $(\mathrm{g})$ & $\begin{array}{c}\text { BET surface area } \\
\left(\mathrm{m}^{2} / \mathrm{g}\right)\end{array}$ \\
\hline $\mathrm{UO}_{3}$ & 2.96 & 2.91 & 0.49 \\
& 2.16 & 3.03 & 0.35 \\
& 14.52 & 13.94 & 0.55 \\
& 17.48 & 16.97 & 1.34 \\
$\mathrm{U}_{3} \mathrm{O}_{8}$ & 11.99 & 12.10 & \\
& 6.59 & 6.92 & 1.61 \\
$\mathrm{U}_{3} \mathrm{O}_{8}$ (with 5 wt \% & 18.4 & 18.1 & \\
$\mathrm{Gd}_{2} \mathrm{O}_{3}$ ) & & & 0.06 \\
$\mathrm{UO}_{2}$ & 4.92 & 5.19 & 0.79 \\
\hline
\end{tabular}




\subsubsection{Moisture Adsorption Study}

A simple constant-humidity chamber was made by realizing the constant water vapor pressure over a solution of known composition and enclosing such a solution in a standard glass dessicator to equilibrate with the atmosphere within. If the solute component has no measurable volatility, as in the case of sulfuric acid, the water vapor pressure can be set by merely adjusting the acid concentration to a predetermined value. Sulfuric acid solutions have long been used for this purpose, and data reporting water vapor pressure versus acid concentration (or specific gravity) are readily available (Table 2.2 ). ${ }^{3}$ A dilute solution of sulfuric acid of the proper specific gravity was simply poured into the normally used dessicant space below the dessicator sample plate. The uranium oxide samples were then placed on the sample plate in open dishes so that they could equilibrate with the enclosed atmosphere in the dessicator. These samples were weighed and stirred daily to expose fresh oxide surface to the atmosphere in the dessicator after each weighing. Earlier work showed that the porcelain dishes themselves would adsorb a measurable amount of moisture during the humidification process. Therefore, the empty dish was preequilibrated in the system prior to placing the sample in the dish. This procedure of frequently stirring the solid oxide powder achieved a maximum adsorption rate to establish a "worst-case" situation for moisture adsorption. Relative humidities less than $100 \%$ were chosen to discourage water condensation on the sample itself, which could occur because of slight temperature variations. Two humidity values were selected for this study: $97.5 \%$ (solution density $=1.05 \mathrm{~g} / \mathrm{mL}$ ) to present the maximum humidity to the samples without risk of liquid condensation on the sample and $70 \%$ (solution density $=1.25 \mathrm{~g} / \mathrm{mL}$ ) to present a humidity more typical of that which might be encountered in this geographic region. This simple system thus provided a convenient means of tracking the moisture adsorption on a practical time scale, while the frequent stirring exposed a maximum amount of sample to the humid atmosphere. Other approaches could be used to produce varying rates and degrees of exposure, but it should be realized that the results are very dependent on the particular method selected. Once the samples had been exposed to moisture in the above fashion, they were examined by differential thermal analysis and thermogravimetric analysis (DTA/TGA) to establish the weight loss as a function of time during heating in an inert atmosphere. In addition, other samples were simply heated in a furnace at three fixed temperatures (120, 400 , and $650^{\circ} \mathrm{C}$ ) to record the gross weight loss at each stage - an approach that one might use in actually drying the stored ${ }^{233} \mathrm{U}$ oxides. 
Table 2.2. Constant humidity with sulfuric acid solutions ${ }^{a}$

\begin{tabular}{ccc}
\hline Density of solution & Relative humidity $(\%)$ & $\begin{array}{c}\text { Vapor pressure at } 20^{\circ} \mathrm{C} \\
(\mathrm{mm} \mathrm{Hg})\end{array}$ \\
\hline 1.00 & 100.0 & 17.4 \\
1.05 & 97.5 & 17.0 \\
1.10 & 93.9 & 16.3 \\
1.15 & 88.8 & 15.4 \\
1.20 & 80.5 & 14.0 \\
1.25 & 70.4 & 12.2 \\
1.30 & 58.3 & 10.1 \\
1.35 & 47.2 & 8.3 \\
1.40 & 37.1 & 6.5 \\
1.50 & 18.8 & 3.3 \\
1.60 & 8.5 & 1.5 \\
1.70 & 3.2 & 0.6 \\
\hline
\end{tabular}

${ }^{a}$ From Handbook of Chemistry and Physics, 41st ed. Chemical Rubber Publishing Co., Cleveland, 1959, p. 2500.

\subsection{GAMMA RADIOLYSIS EXPERIMENTS}

Two different sources of gamma radiation were used: (1) the ORNL ${ }^{60} \mathrm{Co}$ irradiator and (2) High Flux Isotope Reactor (HFIR) spent nuclear fuel (SNF) elements. At the completion of an irradiation, gas and solid samples were taken and analyzed.

\subsection{1 ${ }^{60} \mathrm{Co}$ Irradiation Experiments}

A J. L. Shepherd Model 109-68 (Serial No. 654) ${ }^{60}$ Co gamma irradiator, providing a dose rate of about $10^{5} \mathrm{rad} / \mathrm{h}$, was used for the experiments (Fig. 2.1). A photograph of the irradiation chamber with sample containers installed is shown as Fig. 2.2. A detailed description of the irradiator is provided in ref. 2 .

The exposure-rate profile provided by the manufacturer for the irradiator is shown in Fig. 2.3. The reported exposure rate in the center of the irradiation chamber (i.e., the 100\% rate) on December 9, 1977, 
ORNL Photo 3063-2000

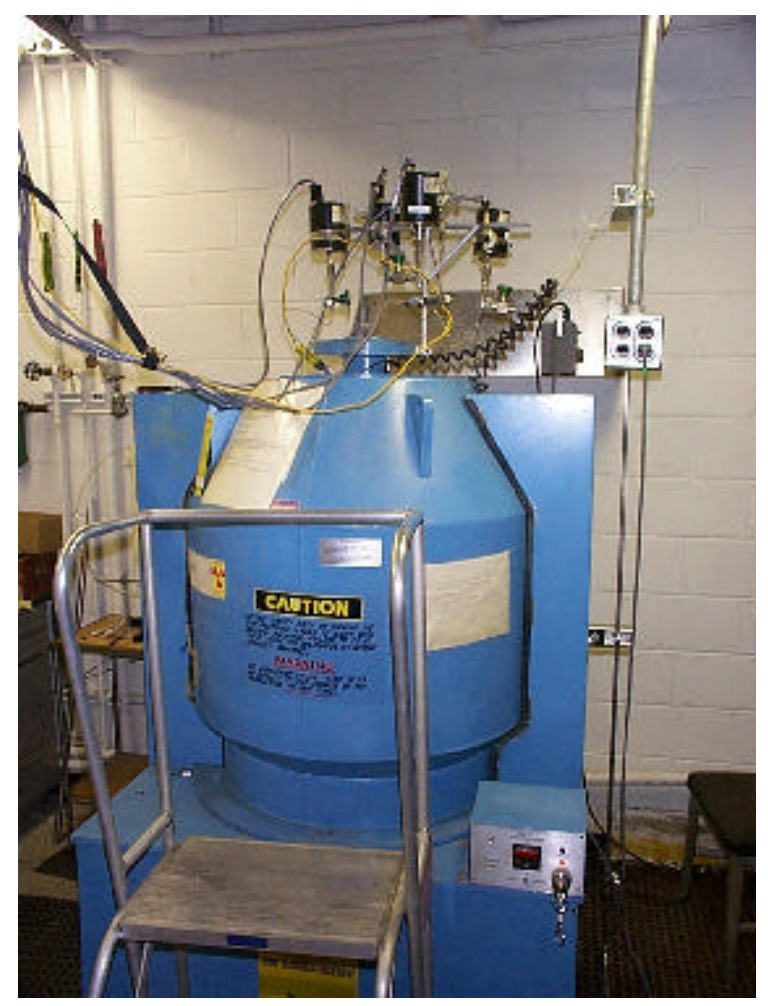

Fig. 2.1. ORNL ${ }^{60} \mathrm{Co}$ irradiator.

ORNL Photo 3064-2000

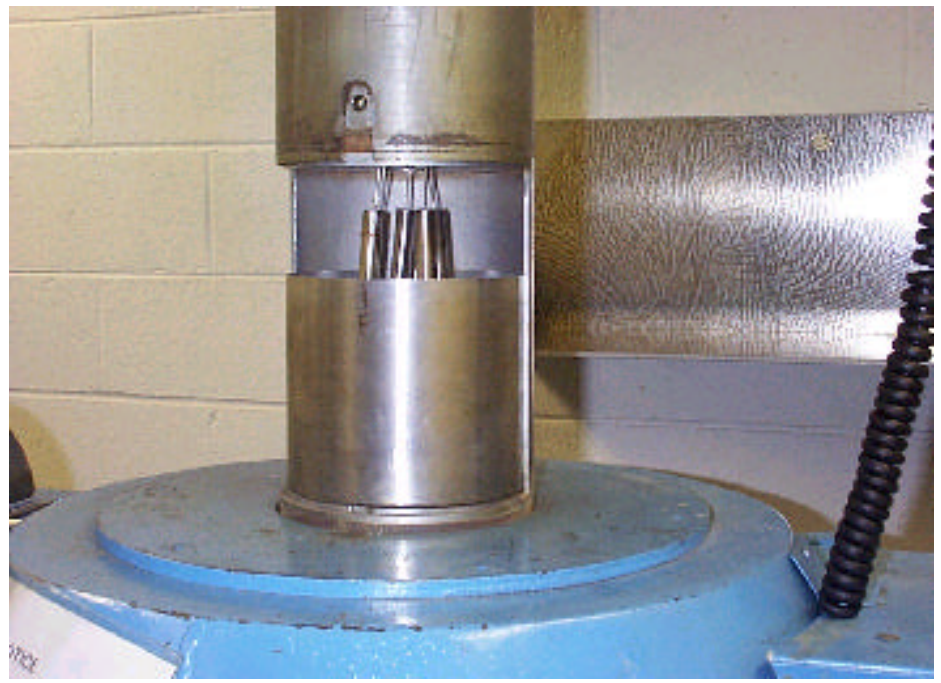

Fig. 2.2. Irradiation chamber of ORNL ${ }^{60} \mathrm{Co}$ irradiator with sample containers installed. 


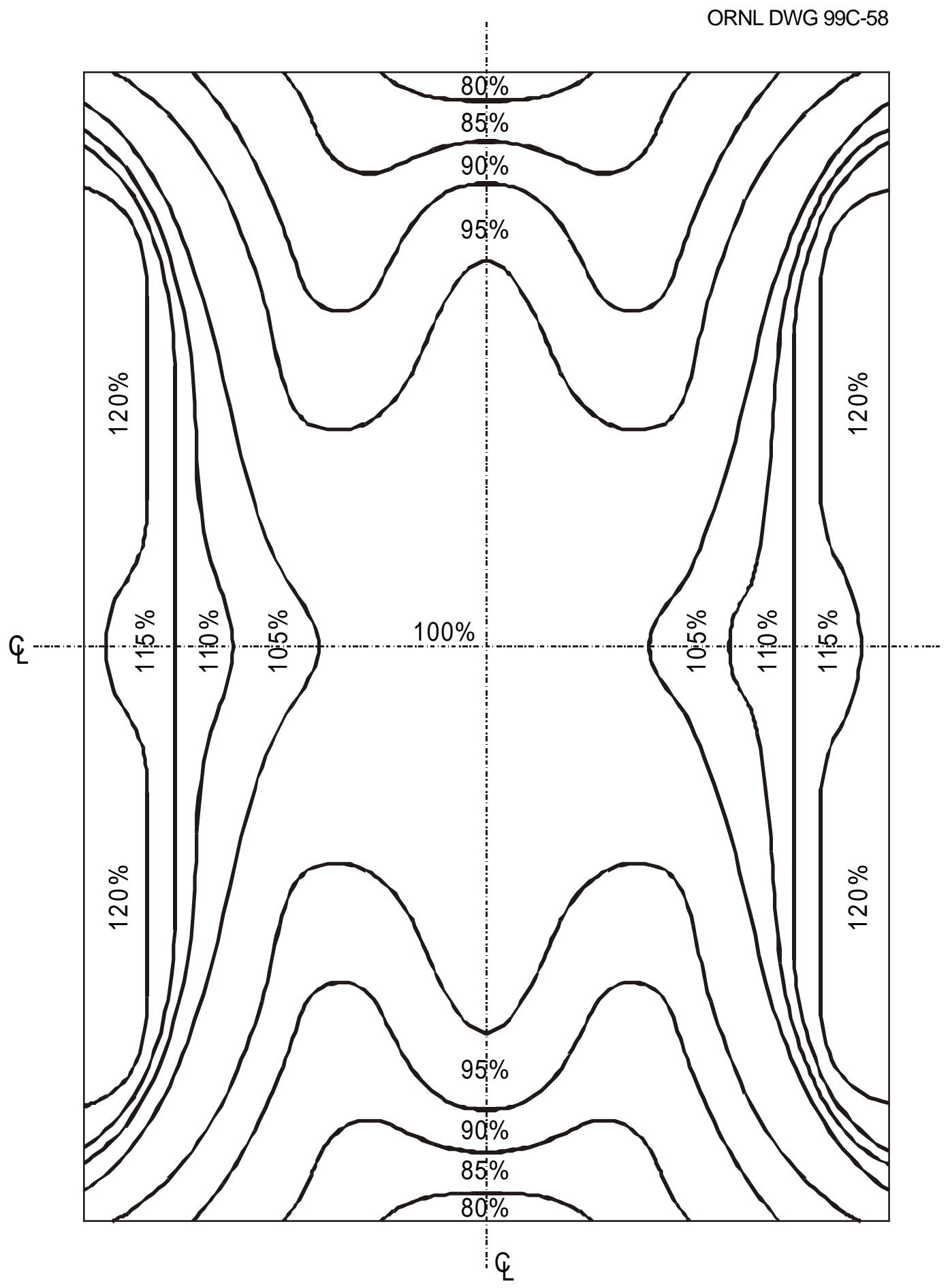

Fig. 2.3. Exposure-rate profile for $\mathrm{ORNL}{ }^{60} \mathrm{Co}$ irradiation chamber.

(Reported 100\% exposure rate on December 9, 1977, was $1.85 \times 10^{6} \mathrm{R} / \mathrm{h}$ ) (after ref. 4). 
was $1.85 \times 10^{6} \mathrm{R} / \mathrm{h} .{ }^{4}$ Unpublished exposure-rate measurements made in 1982 and 1993 showed good agreement with the expected exposure rate that was estimated from the manufacturer's data. ${ }^{5}$

To evaluate radiolytic yields (i.e., the number of molecules of a species produced per amount of energy deposited in a material), the energy deposited in the irradiated material (i.e., the dose) must be known. Hence, the exposure rate (which is a measure of the amount of ionization produced in air by gamma or X-rays) must be converted to a dose rate in the irradiated material. The method established in American Society for Testing and Materials (ASTM) Standard E666-91was used to perform this conversion. ${ }^{6}$ This method is described in Appendix A to this report.

An aluminum spacer disk, with nine evenly spaced holes, was placed in the bottom of the irradiation chamber to hold sample containers. This spacer disk ensured that the samples remained in a fixed position throughout their insertion into and removal from the "irradiate" position. Additionally, because the dose rate varies as a function of both the axial and radial position in the chamber (Fig. 2.3), the disk provided a convenient means by which to index the sample container position. As it turned out, the configuration of the containers resulted in the irradiated materials being located in the $100 \%$-exposurerate region of the chamber.

\subsubsection{Sample containers}

Sample containers, instrumented with pressure transducers, provided for the real-time monitoring of pressure inside the container and for withdrawing gas samples at the end of an irradiation. The interior volume of the containers and associated components (i.e., tubing, fittings, valves, and pressure transducers) was minimized inasmuch as practicable to provide greater sensitivity to pressure changes within the container.

The samples to be irradiated were placed in stainless steel containers, each of which had a smalldiameter nickel tube connected at one end for pressure sensing and a capped opening at the other end for loading samples (Fig. 2.4). The sample containers were constructed from 11.75-cm (4.625-in.)-long, 1.27 -cm (0.5-in.)-diam type 304L stainless steel tubing. The wall thickness of the tubing was $0.089 \mathrm{~cm}$ (0.035 in.). One end of the tube was welded closed with a 1.27-cm (0.5-in.)-diam, 0.159-cm (0.0625-in.)-thick stainless steel disk. A hole in the center of the disk was connected to $0.159-\mathrm{cm}$ (0.0625-in.)-diam nickel tubing [ 84-cm (33-in.)-long]. A small disk of 100-mesh Monel was placed inside the sample container and over the hole leading to the nickel tubing. This mesh prevented the movement of particles from the sample container into the tubing. The sample tubing was connected to a $0.159-\mathrm{cm}\left(0.0625\right.$-in.) stainless steel Swagelok ${ }^{\circledR}$ tee. The tee was then connected to (1) a $0.318-\mathrm{cm}$

${ }^{*}$ While nickel was not considered necessary for these particular experiments, it was part of a system used in an earlier fluoride irradiation study. 


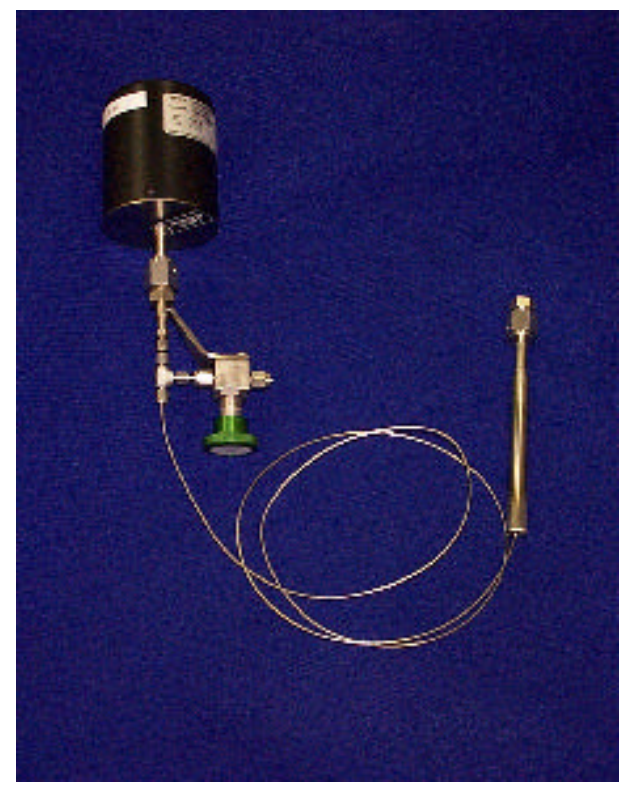

Fig. 2.4. Sample container and pressure transducer used in the ${ }^{60}$ Co irradiations.

(0.125-in.) stainless steel Nupro ${ }^{\circledR}$ valve and (2) a 0.635-cm (0.25-in.) Cajon ${ }^{\circledR}$ VCR gland with a male Cajon VCR nut. The valve was oriented such that the metal valve seat(vs the valve bellows) isolated the pressure-sensing line. The valve was capped with a 0.318-cm (0.125-in.) Swagelok plug, except during container preparation (e.g., leak checks and volume measurement) and sampling operations. The Cajon gland was used to mate the sample tubing to a MKS Baratron ${ }^{\circledR}$ pressure transducer (Type 127A). These transducers were custom-made with $0.635-\mathrm{cm}(0.25$-in.) Cajon VCR glands to minimize volume. A nickel gasket was used to seal the connection between the two Cajon glands.

The other end of the stainless steel tubing was welded to a $0.635-\mathrm{cm}(0.25$-in.) stainless steel VCR gland with a female nut. Material to be irradiated was loaded through this gland into the container. A VCR plug and nickel gasket were used to close the opening in the sample tube. The overall length of the sample container was $17.8-\mathrm{cm}$ (7-in.). Each container was etched with a unique number for identification. One of the sample containers, S-7, was not fitted with the sampling tubing and pressure transducer. This arrangement allowed only for withdrawal of gas samples at the end of an experiment, but not for pressure monitoring.

Preparation of sample containers for their insertion into the ${ }^{60} \mathrm{Co}$ irradiator consisted of leak checks, volume measurements, and loading of the samples into the containers. As part of their fabrication, the containers were leak checked with air to a pressure of about 6.8 atm (100 psia). 
Just before their use, the containers were leak checked again using both pressure (typically $\sim 3 \mathrm{~atm}$ ) and vacuum. The volume of the irradiation rig (i.e., the sample container, tubing, valve, and pressure transducer) was measured by expanding helium from a known volume into the rig, observing the pressure change, and applying the ideal gas law. The results of the volume measurements are presented in Table 2.3. Samples were loaded with either an inert (helium) or air atmosphere in the container.

Table 2.3. Volume measurements of irradiation containers as determined by gas expansion method

\begin{tabular}{lc}
\hline \multicolumn{1}{c}{ Container } & Volume $\left(\mathrm{cm}^{3}\right)$ \\
\hline Calibrated volume $^{a}$ & 153.9 \\
S-7 $^{b}$ & 14.1 \\
S-14 & 15.8 \\
S-15 & 17.3 \\
S-17 & 15.9 \\
S-18 & 16.1 \\
S-19 & 16.1 \\
HFIR-2, 3, 4, 5 & 70.5 \\
HFIR-6-1 & 36.0 \\
HFIR-6-2 & 53.8 \\
HFIR-6-3 & 47.8 \\
\hline
\end{tabular}

${ }^{a}$ Measured by weight of water required to fill volume.

${ }^{b}$ S-7 was not fitted with sensing tubing and a pressure transducer. 


\subsubsection{Data acquisition system}

A computerized data acquisition system was used to collect data during each irradiation (Fig. 2.5). Validyne ${ }^{\circledR}$ hardware and software were used, providing up to eight data channels per card. Typical parameters recorded during an irradiation included container pressure, temperature of selected containers, and ambient pressure and temperature.

Omega $^{\circledR}$ Type K thermocouples and MKS Baratron Type 127A pressure transducers were used to measure temperature and pressure, respectively.

\subsubsection{Materials irradiated}

Samples of $\mathrm{U}_{3} \mathrm{O}_{8}$ and $\mathrm{UO}_{3}$ with varying water contents were used in these experiments. These samples were prepared from one of the following: (1) materials on hand at ORNL (S-7, S-14, S-15); (2) material produced in the conversion $\operatorname{prototype}^{7}(\mathrm{~S}-17)$; or (3) materials prepared at ORNL for the water sorption studies, as described in Sect. 2.1.1 (S-18, S-19).

\subsubsection{HFIR SNF Irradiation Experiments}

To obtain higher dose rates, the HFIR SNF gamma irradiation facility, which is located at ORNL, was also used. Samples can be irradiated in the HFIR SNF pool by inserting them inside SNF elements (Fig. 2.6). The SNF elements are cylindrical with a hollow center. In its storage position in the SNF pool, a cadmium sleeve inside the hollow region of the element absorbs neutrons. Hence, the hollow region of the fuel element primarily provides a gamma field for irradiation. The neutron flux in this region is about 100 neutrons $\mathrm{cm}^{\mathrm{G} 2} \cdot \mathrm{s}^{\mathrm{Gl}}$. The contribution of neutrons to the radiation damage is negligible when comparted with the very large gamma field. Exposure rates vary from about $10^{8}$ to $10^{7} \mathrm{R} / \mathrm{h}$ or lower, depending on the time since the discharge of the SNF from the reactor. The gamma-ray energy spectrum for a HFIR SNF element $1 \mathrm{~d}$ after discharge from the reactor is shown in Table 2.4. ${ }^{8}$

M. W. Kohring measured the exposure rate inside HFIR SNF elements as a function of (1) axial location within the element and (2) time since discharge from the reactor. ${ }^{9}$ These measurements were made for elements that had been operated at $100 \mathrm{MW}$ for $21.5 \mathrm{~d}$ (i.e., 2150-MWd burnup). Figure 2.7 shows the peak exposure rate as a function of time since shutdown. This exposure rate can be corrected for the axial location of the sample by use of Fig. 2.8, which is adapted from ref. 9. In 1987, HFIR operating power was reduced to $85 \mathrm{MW}$. This reduced power level necessitated an adjustment in the reported exposure rates, and such an adjustment was calculated by Kohring. ${ }^{10}$ Kohring used the ORIGEN computer code to calculate correction factors that needed to be applied to the measured 
ORNL Photo 3066-2000

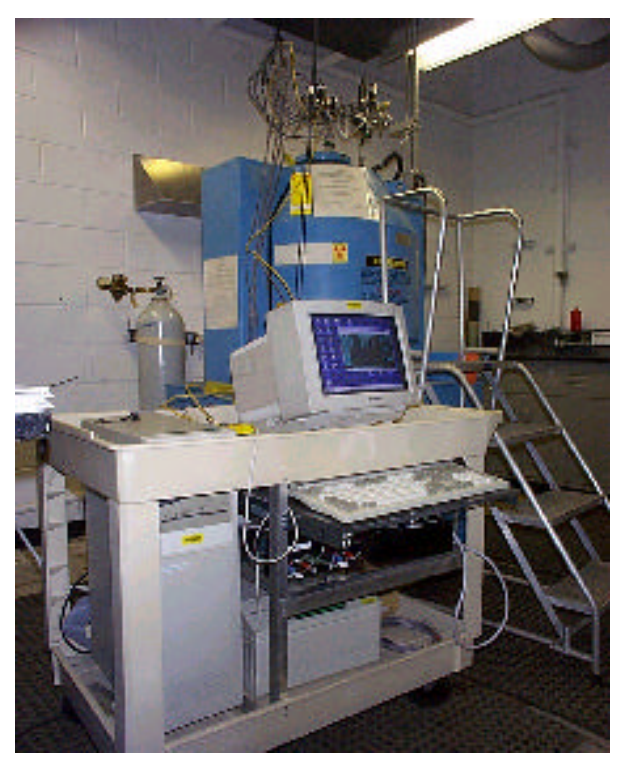

Fig. 2.5. Photograph of data acquisition computer in operation at the ORNL ${ }^{60} \mathrm{Co}$ source.

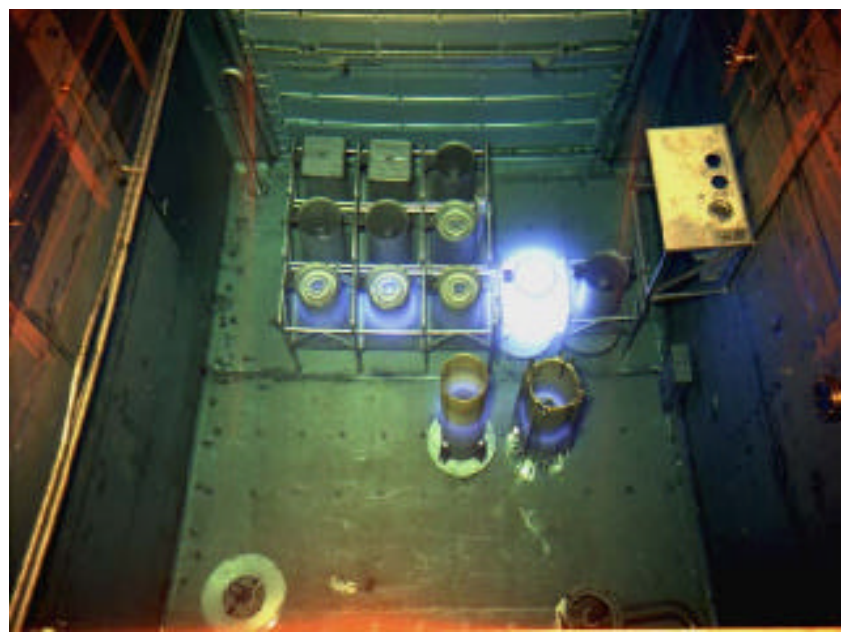

Fig. 2.6. SNF elements in the HFIR SNF pool. 
Table 2.4. Gamma-ray energy spectrum for a HFIR SNF element $1 \mathrm{~d}$ after discharge from the reactor ${ }^{a}$

\begin{tabular}{|c|c|c|c|}
\hline $\begin{array}{l}\text { Energy } \\
\text { group }\end{array}$ & Upper bound (MeV) & $\begin{array}{l}\text { Average energy in group } \\
\qquad(\mathrm{MeV})\end{array}$ & $\begin{array}{l}\text { Percentage of } \\
\text { total energy in } \\
\text { group }\end{array}$ \\
\hline 1 & 0.02 & 0.01 & 0.44 \\
\hline 2 & 0.03 & 0.025 & 0.44 \\
\hline 3 & 0.045 & 0.0375 & 0.89 \\
\hline 4 & 0.07 & 0.0575 & 0.56 \\
\hline 5 & 0.1 & 0.085 & 1.04 \\
\hline 6 & 0.15 & 0.125 & 2.66 \\
\hline 7 & 0.3 & 0.225 & 5.66 \\
\hline 8 & 0.45 & 0.375 & 4.48 \\
\hline 9 & 0.7 & 0.575 & 26.94 \\
\hline 10 & 1 & 0.85 & 26.82 \\
\hline 11 & 1.5 & 1.25 & 6.89 \\
\hline 12 & 2 & 1.75 & 21.06 \\
\hline 13 & 2.5 & 2.25 & 0.88 \\
\hline 14 & 3 & 2.75 & 1.24 \\
\hline 15 & 4 & 3.5 & 0.01 \\
\hline \multicolumn{4}{|c|}{ Average energy $=0.93 \mathrm{MeV}$} \\
\hline
\end{tabular}

${ }^{a}$ Adapted from D. F. Williams, G. D. Del Cul, and L. M. Toth, A Descriptive Model of the Molten Salt Reactor Experiment After Shutdown: Review of FY 1995 Progress, ORNL/TM-13142, Lockheed Martin Energy Research Corp., Oak Ridge National Laboratory, Oak Ridge, Tennessee, January 1996. 


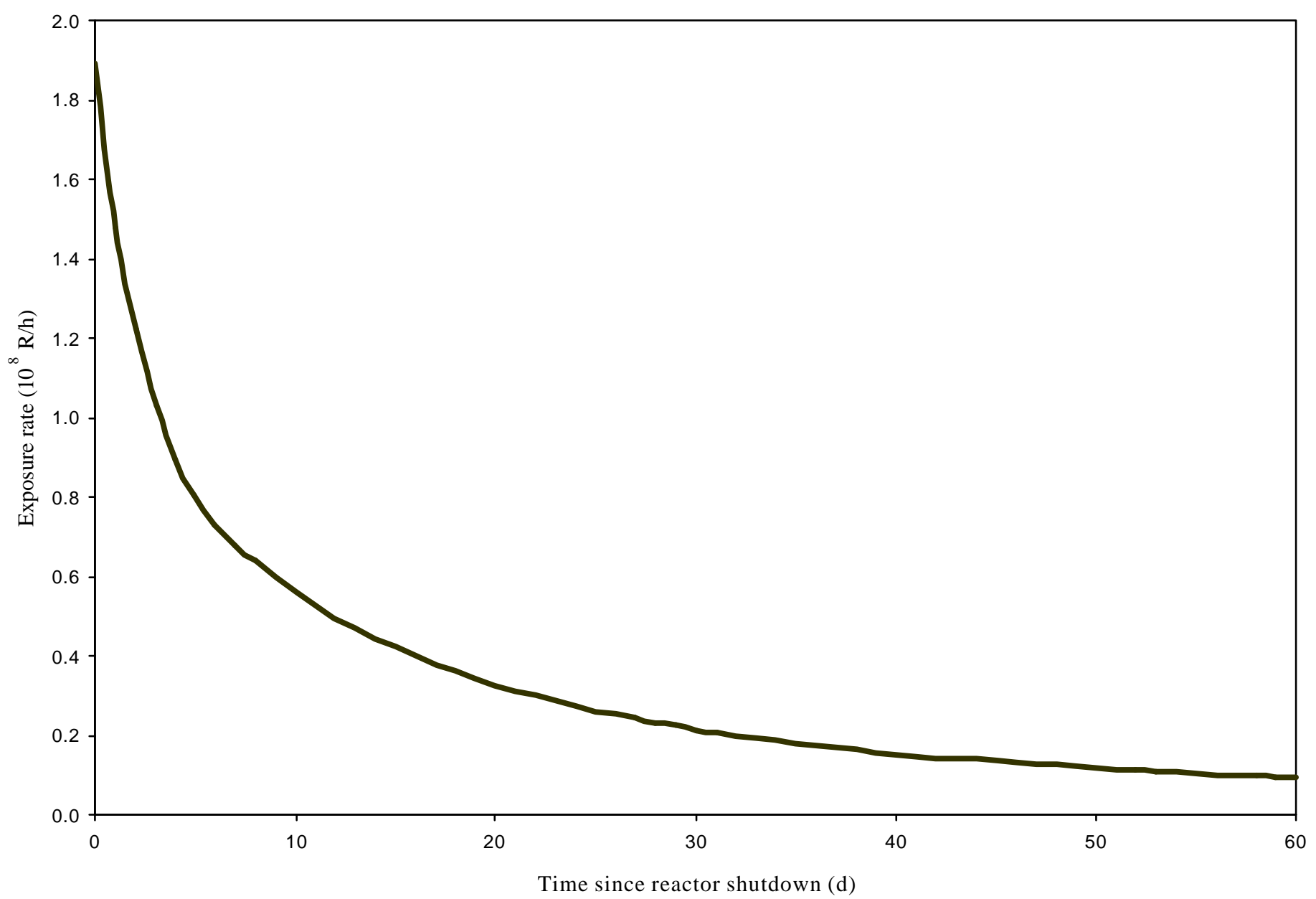

Fig. 2.7. Peak exposure rate in a HFIR SNF element as a function of time since reactor shutdown. (Adapted from M. W. Kohring, Gamma Flux Measurements on High Flux Isotope Reactor (HFIR) Fuel Assemblies, ORNL/CF-86/256, Martin Marietta Energy Systems, Oak Ridge National Laboratory, Oak Ridge, Tennessee, August 7 , 1986.) 


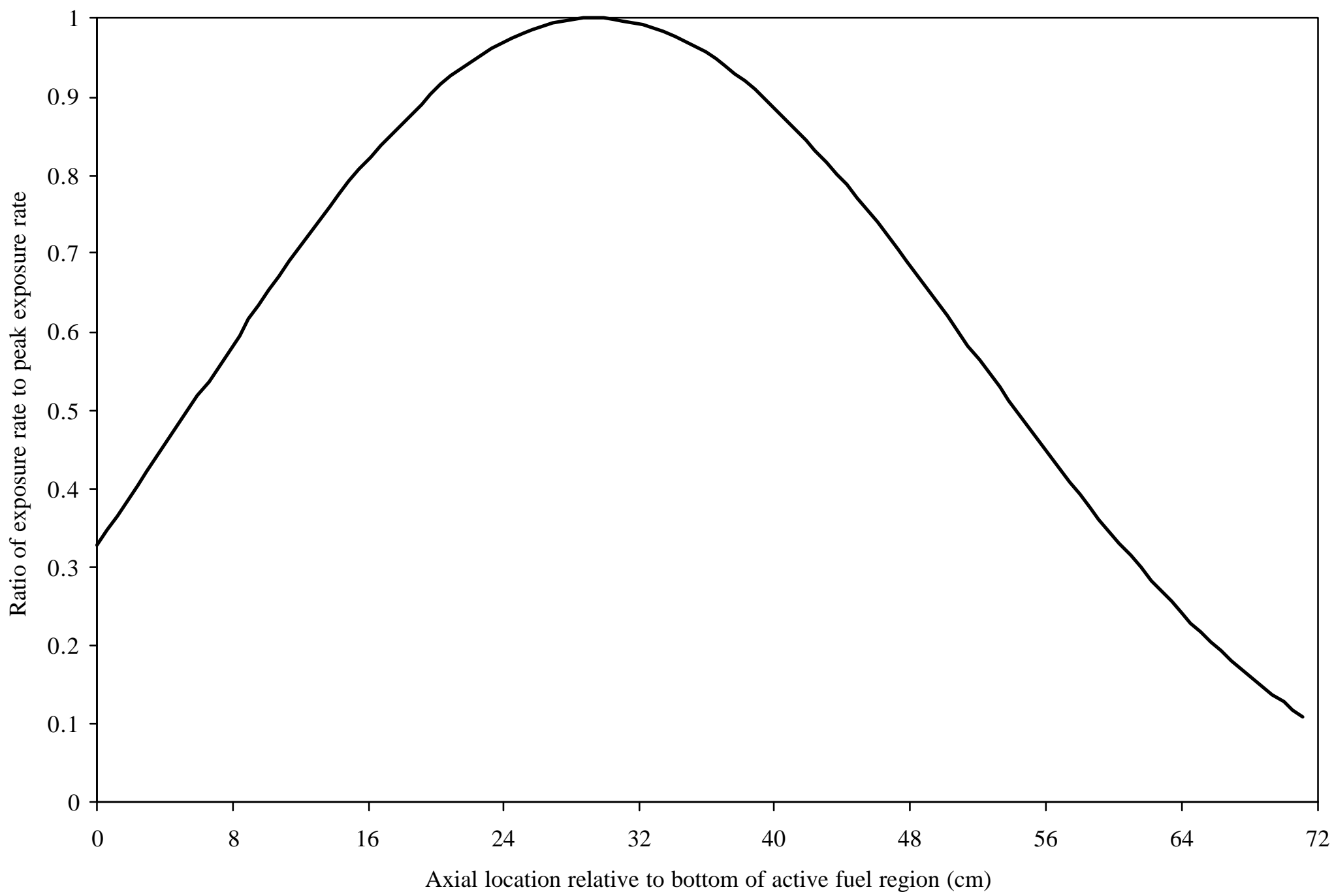

Fig. 2.8. Ratio of exposure rate to the peak exposure rate as a function of axial position in a HFIR SNF element. (Adapted from M. W. Kohring, Gamma Flux Measurements on High Flux Isotope Reactor (HFIR) Fuel Assemblies, ORNL/CF86/256, Martin Marietta Energy Systems, Oak Ridge National Laboratory, Oak Ridge, Tennessee, August 7, 1986.) 
exposure rates to account for the decreased operating power. These correction factors can also be calculated by use of the Borst-Wheeler formula, ${ }^{11}$ which has been shown to be in good agreement with the correction factors reported by Kohring. ${ }^{12}$ The correction factor is calculated by

$$
C F(t)=0.85 \frac{\left(t^{-0.2}-(t+T)^{-0.2}\right)}{\left(t^{-0.2}-(t+21.5)^{-0.2}\right)}
$$

where

$$
\begin{array}{lll}
C F(t) & = & \text { correction factor at time } t \text { after shutdown (unitless), } \\
t & = & \text { time since shutdown (d), and } \\
T & = & \text { time of operation at } 85 \mathrm{MW}[=\text { burnup (MWd)/85 MW] (d). }
\end{array}
$$

The factor 0.85 is simply the ratio of the new operating power level (85 MW) to the original operating power level (100 MW). To evaluate the dose rate to a sample, the exposure-rate data provided by Kohring are adjusted based on the burnup of the element and the axial location of the sample. The exposure is then converted to dose based on the method described in Appendix A.

\subsubsection{Sample containers}

Two types of vessels were used in the HFIR SNF irradiations. A single small vessel was used to irradiate one sample at a time. A larger vessel, containing multiple sample vessels, allowed for the irradiation of up to four samples at one time.

\section{Small-vessel experiments}

The single small vessel has been used in a number of radiolysis experiments on Molten Salt Reactor Experiment (MSRE)-type salts ${ }^{8,13}$ and on fluoride impurities in uranium oxides. ${ }^{2}$ This container (Fig. 2.9) was fabricated from a 2.54-cm (1-in.)-diam, 8.9-cm (3.5-in.)-long nickel tube, which is sealed at one end with nickel plate and has a Conflat ${ }^{\circledR}$ flange at the other end. A hole in the flange was connected to $6.1 \mathrm{~m}$ (20 ft) of 0.318-cm (0.125-in.)-diam Monel tubing, which was then connected to an Ashcroft ${ }^{\circledR}$ compound pressure gage and a valve for withdrawing gases.

Samples were loaded into the container through the flanged end, either in an inert-atmosphere glove box or in air. The flange was then sealed with an aluminum gasket. Before the container was sent to the HFIR for its insertion into an SNF element, the pressure in the container was increased to $1.7 \mathrm{~atm}$ (10 psig) with helium because of requirements imposed by HFIR personnel to maintain the container pressure greater than the water pressure in the SNF pool. Therefore, even samples initially loaded in air 
ORNL DWG 99C-6863A

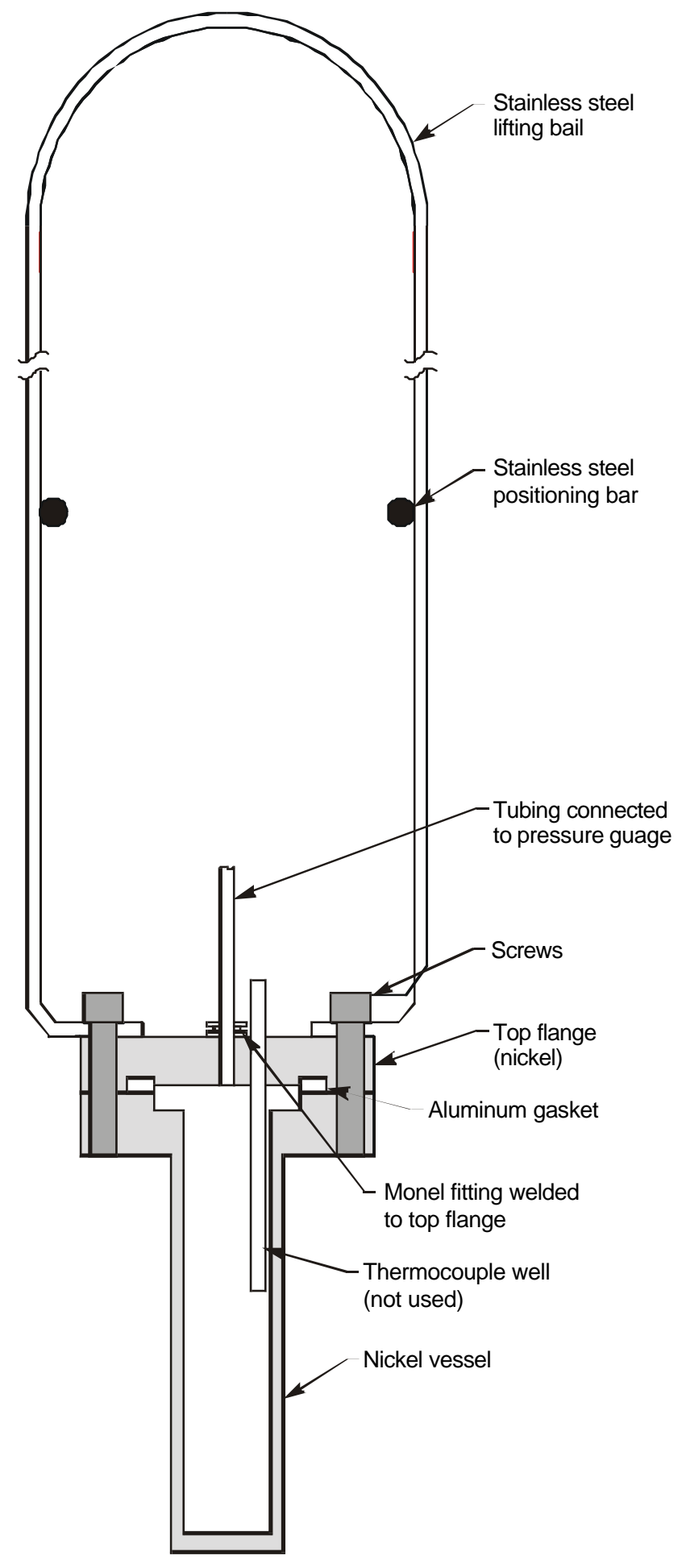

Fig. 2.9. Schematic of nickel container used in the HFIR SNF small-vessel irradiations. 
had an overpressure of helium introduced. A sketch of the experimental configuration used for irradiation of samples in HFIR SNF elements is shown in Fig. 2.10.

A lifting bail attached to the flange was used to direct the container into position in the SNF element. Positioning rods on the lifting bail held the sample about $37 \mathrm{~cm}$ (14.5 in.) above the bottom of the active region of the fuel element.

This container was used in four of the experiments (HFIR-2, HFIR-3, HFIR-4, and HFIR-5), and the void volume of the container is shown in Table 2.3.

\section{Multiple-irradiation container}

A multiple-irradiation container was used for the irradiation of up to four samples at once (Fig. 2.11). Small sample containers consisting of $1.27 \mathrm{~cm}$ (0.5 in.)-diam Monel tubing were placed inside an outer container, which was fabricated from 8.9-cm (3.5-in.)-diam, 44-cm (17.34-in.)-long stainless steel pipe. The outer container was closed at one end and had a Conflat flange on the other end. There were five penetrations in the flange. Four of the penetrations were used to connect the smaller inner containers to 0.318-cm (0.125-in.)-diam stainless steel tubing. The fifth penetration connected the void volume of the outer container to $0.318-\mathrm{cm}(0.125$-in.)-diam stainless steel tubing. In each case, the 0.318 -cm $(0.125$ in.)-diam tubing was about $6.1 \mathrm{~m}(20 \mathrm{ft})$ long and was connected to a pressure transducer and to a valve.

Three of the sample containers (designated HFIR-6-1, HFIR-6-2, and HFIR-6-3) were used in these experiments. The volumes of these containers are listed in Table 2.3. The samples were loaded in air and the outer container was pressurized to $10 \mathrm{psig}$ (as required by HFIR operations personnel) before the experiment was transported to the HFIR for insertion in an SNF element.

\subsubsection{Data acquisition system}

For the small-vessel experiments, a Monel Bourdon pressure gage was used for the HFIR SNF irradiations. The pressure gage and a valve were attached to a mounting bracket, which was clamped to the edge of the SNF pool wall (Fig. 2.10). The container was then inserted into an SNF element, and HFIR operations personnel periodically recorded the container pressure.

For the multivessel experiments, Sensotec ${ }^{\circledR}$ (Model FPA, 0-50 psia) pressure transducers were used for the four inner sample containers. A Kobold ${ }^{\circledR}$ (Model KPK, 30 in. Hg to 100 psig) compound pressure transducer was used to monitor the pressure in the large outer vessel. The pressure transducer assembly, mounted on a clamping plate, is shown in Fig. 2.12. Again, this assembly was clamped to the edge of the HFIR SNF pool wall in the manner depicted in Fig. 2.10. A computerized data acquisition system was used to record the pressure throughout the experiments. 


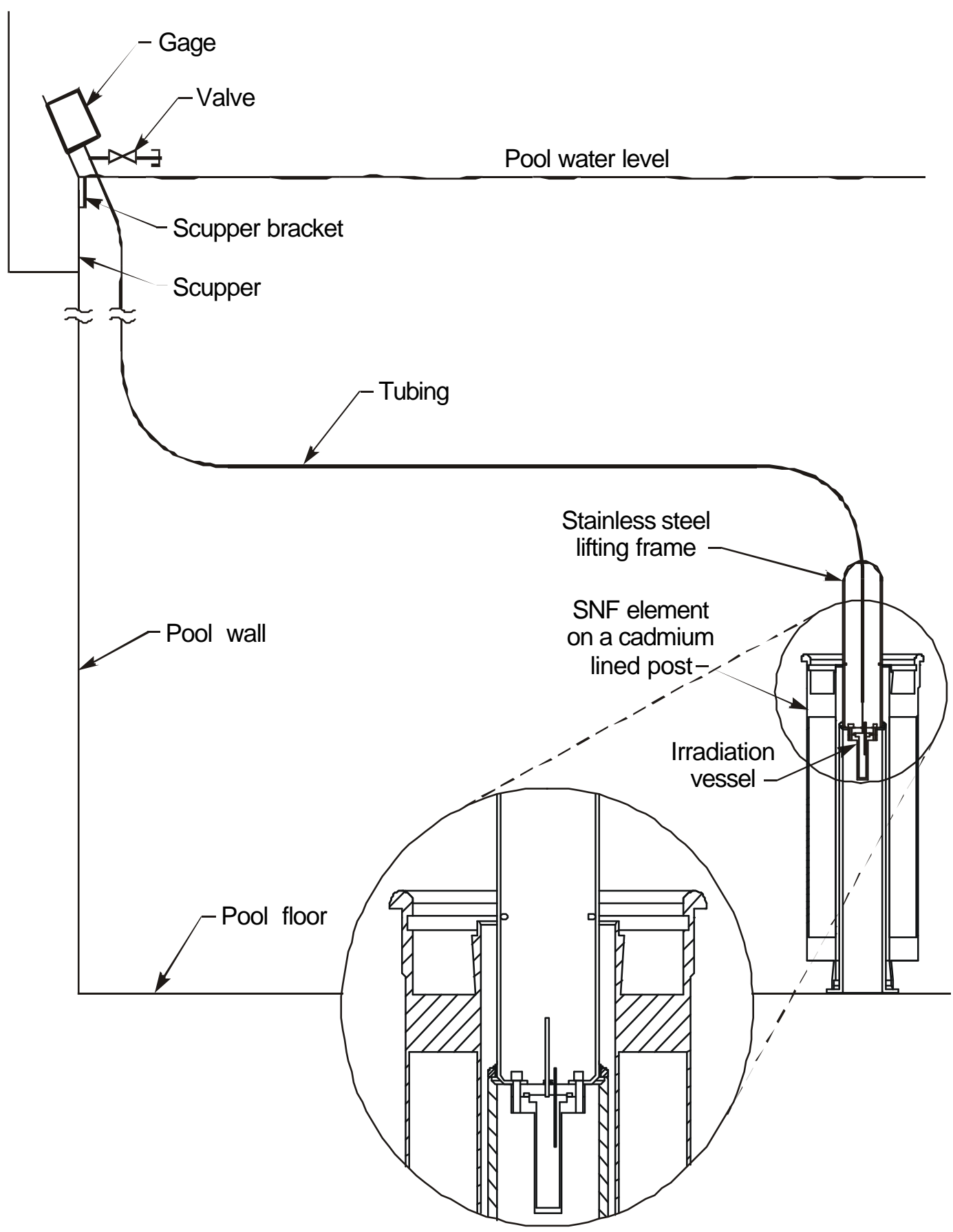

Fig. 2.10. Schematic of the experimental configuration for gamma irradiation experiments with a HFIR SNF element. 
ORNL Photo 01203-2001

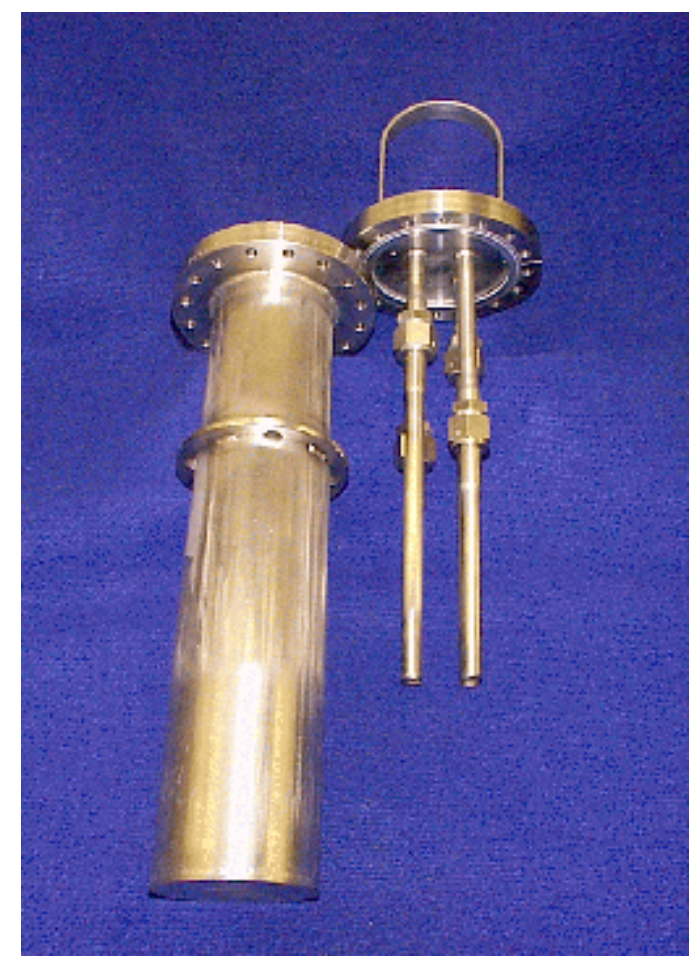

Fig. 2.11. Multiple-irradiation container used in HFIR SNF irradiations.

ORNL Photo 01202-2001

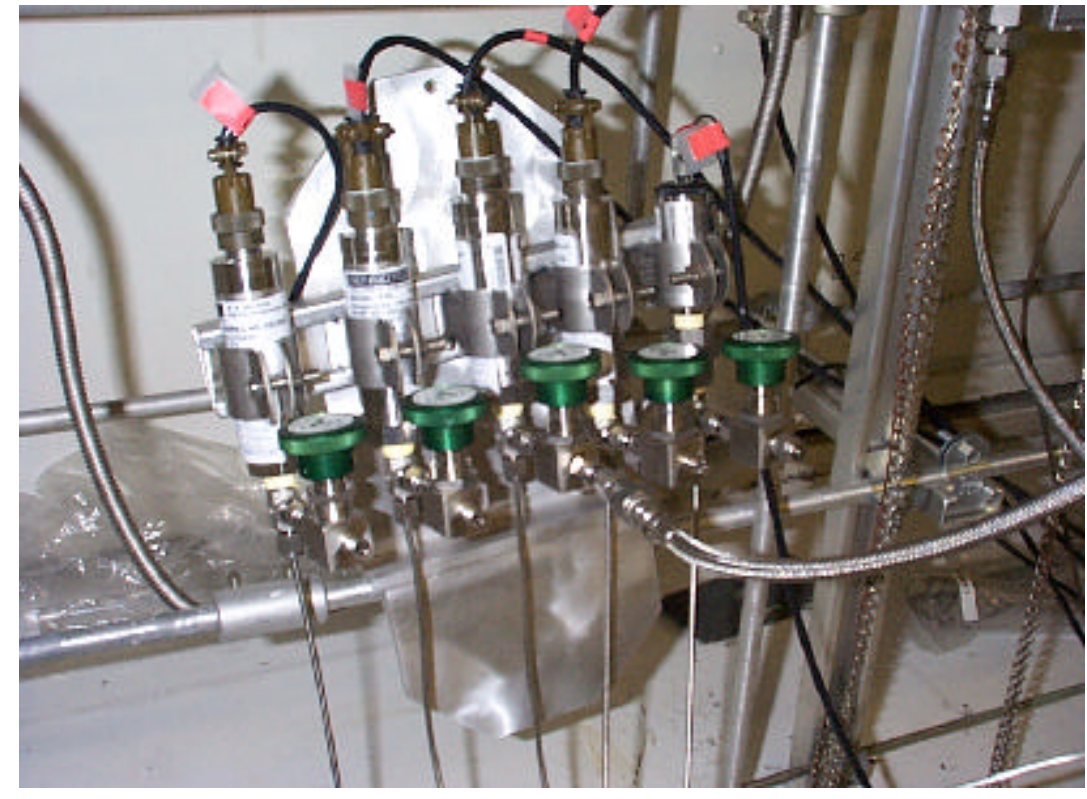

Fig. 2.12. Pressure transducer assembly that was connected to the multiple-irradiation container and used in HFIR SNF irradiations. 


\subsubsection{Materials irradiated}

Samples of $\mathrm{U}_{3} \mathrm{O}_{8}$ and $\mathrm{UO}_{3}$ with varying water contents were used in these experiments. These samples were either from (1) material produced in the conversion prototype ${ }^{7}$ (HFIR-2, HFIR-3) or (2) materials prepared at ORNL for the water sorption studies as described in Sect. 2.1.1 (HFIR-4, HFIR-5, HFIR-6-1, HFIR-6-2, HFIR-6-3).

\subsection{SAMPLING AND ANALYSES}

At the completion of the irradiations, gas samples were withdrawn and analyzed by mass spectrometry and Fourier transform infrared (FTIR) spectroscopy. To withdraw gas samples, the irradiation rig was connected to a sampling rig (Fig. 2.13), which consisted of a sample cylinder for mass spectrometry connected in series to a 10-cm FTIR gas cell. Zinc selenide windows were used in the FTIR gas cells. The uranium valence of some solid samples was analyzed by Davies-Gray titration. ${ }^{14,15,16}$

ORNL DWG 99C-6862

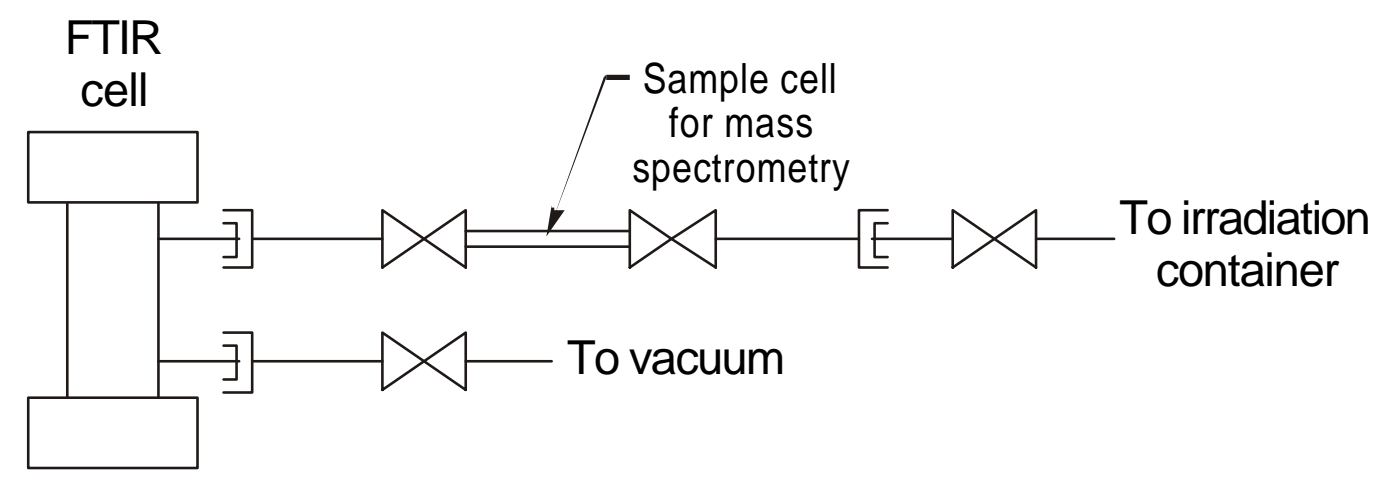

Fig. 2.13. Schematic of sampling rig used to withdraw gas samples from an irradiation container. 


\section{RESULTS}

The results from the water sorption studies are described in Sect. 3.1, while the results from the gamma radiolysis experiments are presented in Sect. 3.2.

\subsection{WATER SORPTION STUDIES}

For the water sorption studies, samples were first placed in an atmosphere of known humidity and the weight increase in the sample was recorded as a function of time. Desorption of the water from the sample was then studied by heating in a furnace or through the use of a DTA/TGA apparatus.

\subsubsection{Humidification of Uranium Oxides}

The rate of humidification (i.e., the rate at which the oxides adsorbed water from an atmosphere of constant humidity) was examined at high $(97.5 \%)$ and moderate $(70 \%)$ relative humidities. Still lower humidities could have been examined and would certainly produce lower rates of humidification. However, these lower-humidity studies were not deemed necessary for testing after seeing the dramatic trends represented by the data for 97.5 and $70 \%$ humidification.

\subsubsection{UO $\mathrm{UO}_{3}$}

Two moisture adsorption tests have been performed with anhydrous $\mathrm{UO}_{3}$ exposed to $97.5 \%$ humidity using differing amounts of material ( 2 and $12 \mathrm{~g}$, respectively). Both tests showed rapid initial rates of adsorption followed by slower rates until saturation was reached. Figure 3.1 gives the percentage weight gain as a function of time for the two samples. The 2-g sample increased $14 \%$ in weight after $24 \mathrm{~h}$ and continued to gain weight, reaching weight gains of 28 and $33 \%$ after 10 and 28 d, respectively. The 12-g sample gained $5.3 \%$ in $24 \mathrm{~h}, 22 \%$ in $20 \mathrm{~d}$, and continued to gain until it reached $23 \%$. On the shorter time basis, the 12-g sample showed as much as a $40-\mathrm{mg}$ increase $(0.33 \% / \mathrm{h})$ initially (as measured after the first hour), then falling off to $20 \mathrm{mg} / \mathrm{h}$ through the first day to give the average $5.3 \%$ for the first $24 \mathrm{~h}$.

When the rate of moisture adsorption was examined for the atmosphere of $70 \%$ relative humidity, a 4-g sample of $\mathrm{UO}_{3}$ showed $6.7 \%$ weight gain in $24 \mathrm{~h}$ and then reached $14 \%$ after $3 \mathrm{~d}$. No further weight gain was noted for the sample. After reaching this point, the sample color had changed from bright orange to the yellow that is typical of the $\mathrm{UO}_{3}$ hydrate. The observed weight gain is representative of $\sim 2.5 \%$ more water weight than that found in the hydrate itself (containing $11.2 \%$ by weight of $\mathrm{H}_{2} \mathrm{O}$ ).

A comparison of the moisture adsorption for the 97.5 and the $70 \%$ relative humidities is shown in Fig. 3.2. 


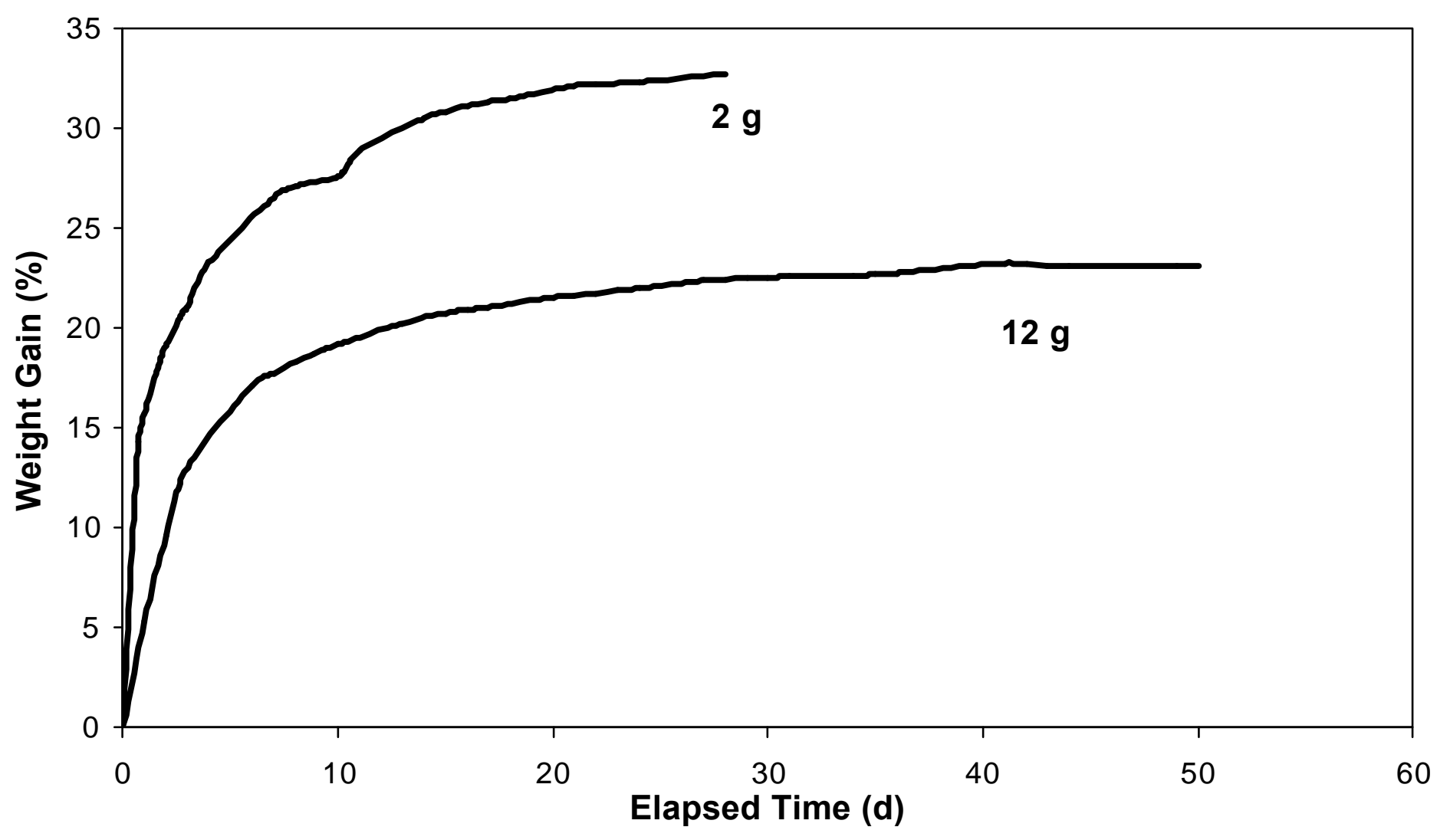

Fig. 3.1. Weight gain for $\mathrm{UO}_{3}$ in $97.5 \%$ relative humidity. 


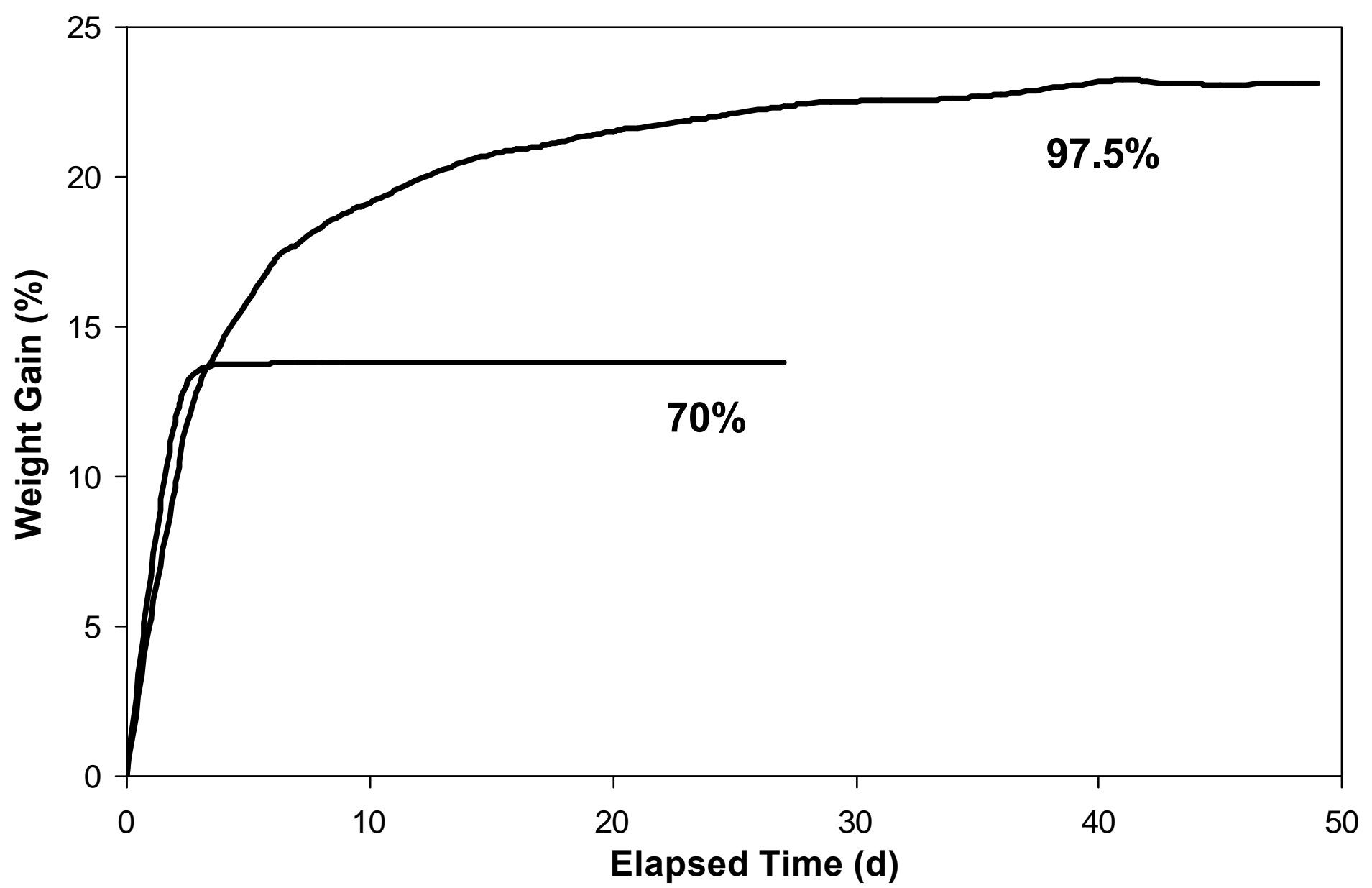

Fig. 3.2. Weight gain for $\mathrm{UO}_{3}$ in 70 and $97.5 \%$ relative humidities. 


\subsubsection{2 $\mathrm{U}_{3} \mathrm{O}_{8}$}

In a similar manner, two determinations of moisture adsorption rate have been performed on $\mathrm{U}_{3} \mathrm{O}_{8}$ samples at $97.5 \%$ relative humidity. As shown in Fig. 3.3, both of these tests showed much lower rates of adsorption than found for the $\mathrm{UO}_{3}$ samples. A 2-g sample of $\mathrm{U}_{3} \mathrm{O}_{8}$ gained $0.47 \%$ weight in $24 \mathrm{~h}$ and reached $1.6 \%$ after $15 \mathrm{~d}$. A 9-g sample of $\mathrm{U}_{3} \mathrm{O}_{8}$ showed $0.35 \%$ weight gain in $24 \mathrm{~h}, 1.68 \%$ after $20 \mathrm{~d}$, and reached $2.8 \%$ after $43 \mathrm{~d}$. This sample continued to gain weight in the $97.5 \%$ humidity, reaching $8 \%$ after $200 \mathrm{~d}$. When anhydrous $\mathrm{U}_{3} \mathrm{O}_{8}$ was placed in a $70 \%$ humidity environment, the rate of adsorption was reduced by about half and approached a limit of 4-5\% after $200 \mathrm{~d}$. A similar sample that also contained $5 \mathrm{wt} \%$ of $\mathrm{Gd}_{2} \mathrm{O}_{3}$ was examined because it had been predicted that the presence of a more hygroscopic oxide mixed with $\mathrm{U}_{3} \mathrm{O}_{8}$ would increase the rate and amount of moisture adsorption. However, this sample showed moisture adsorption rates similar to those of the neat $\mathrm{U}_{3} \mathrm{O}_{8}$. Tests of the rate of humidification of neat $\mathrm{Gd}_{2} \mathrm{O}_{3}$ (data not shown in this report) confirmed that it did not adsorb moisture from these humid atmospheres at any faster rate than did the pure $\mathrm{U}_{3} \mathrm{O}_{8}$ samples. Therefore, no effect from the added $\mathrm{Gd}_{2} \mathrm{O}_{3}$ could be seen.

\subsubsection{3 $\mathrm{UO}_{2}$}

Uranium dioxide did not gain any weight in the atmosphere of $97.5 \%$ relative humidity over a period of 1 month when measured by these techniques.

\subsubsection{Drying Uranium Oxides}

The rate and extent of moisture loss from the uranium oxides were examined in two ways: (1) simple oven drying at selected fixed temperatures and (2) TGA analysis. Because the percent of weight loss can be represented as either the loss as a function of the moisture-saturated sample or the loss as a function of the dry reference sample, we express the percentage loss in both ways, indicating the latter with an asterisk $\left(^{*}\right)$. The advantage of the latter representation is that it can be compared directly with the moisture-gain tests, which also were expressed as percentages based on the anhydrous starting material.

The moisture-saturated $\mathrm{UO}_{3}$ sample lost $20.28 \%(25.45 \%)^{*}$ of weight after being heated at $120^{\circ} \mathrm{C}$ overnight, then lost additional moisture to attain a weight loss of $24.6 \%(32.6 \%)^{*}$ after being heated at $400^{\circ} \mathrm{C}$ overnight, and finally reached a total weight loss of $25.2 \%(33.81 \%)^{*}$ after being heated at $650^{\circ} \mathrm{C}$ for another $24 \mathrm{~h}$. The TGA of this moisture-saturated sample, Fig. 3.4, showed a total weight loss of $24.7 \%(32.83 \%)^{*}$ at a heating rate of $60^{\circ} \mathrm{C} / \mathrm{h}$ and $21.4 \%(27.2 \%)^{*}$ at a $120^{\circ} \mathrm{C} / \mathrm{h}$ heating rate. 


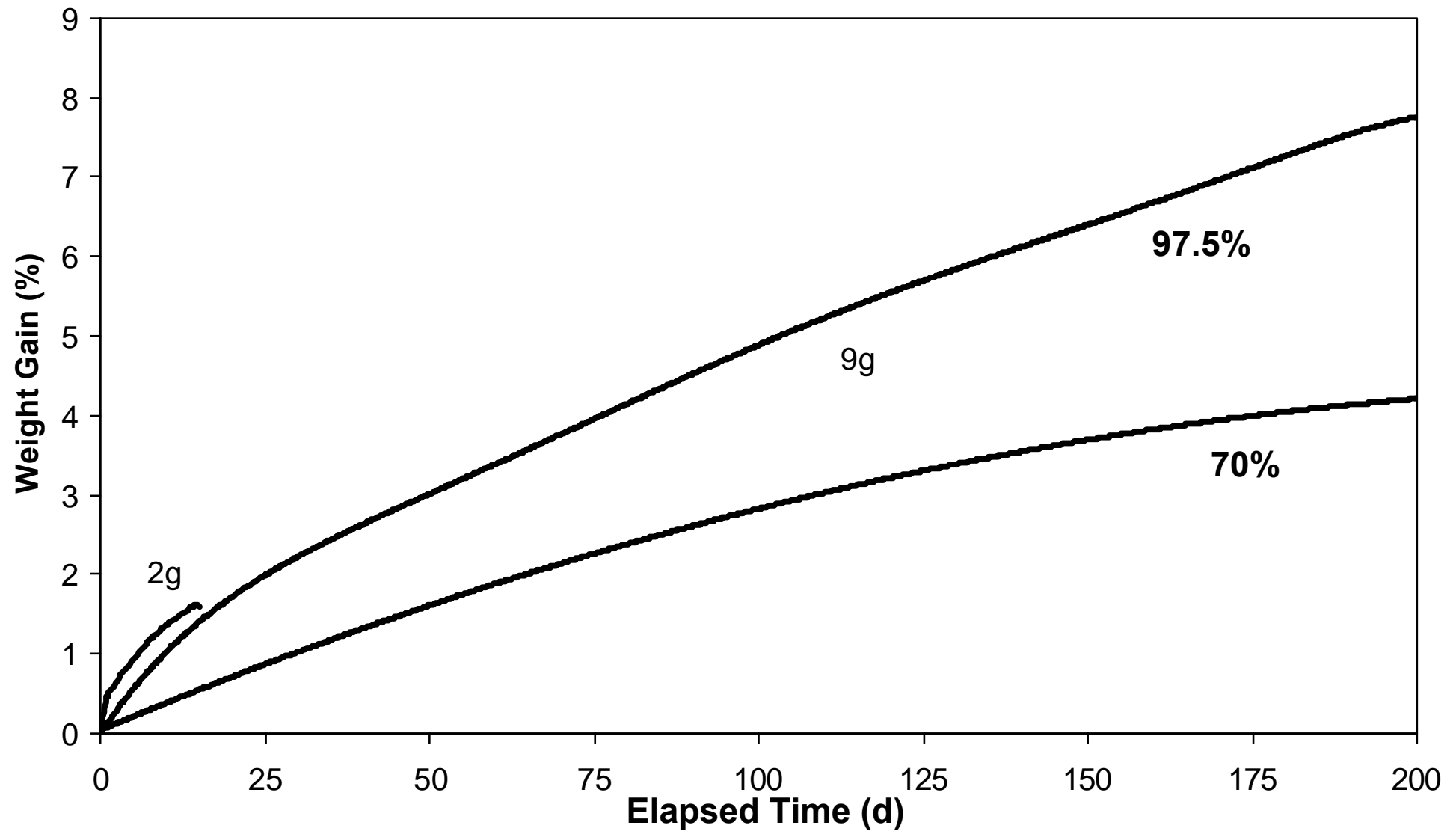

Fig. 3.3. Weight gain for $\mathrm{U}_{3} \mathrm{O}_{8}$ in 70 and $97.5 \%$ relative humidities. (Two different samples are shown for the $97.5 \%$ humidity). 


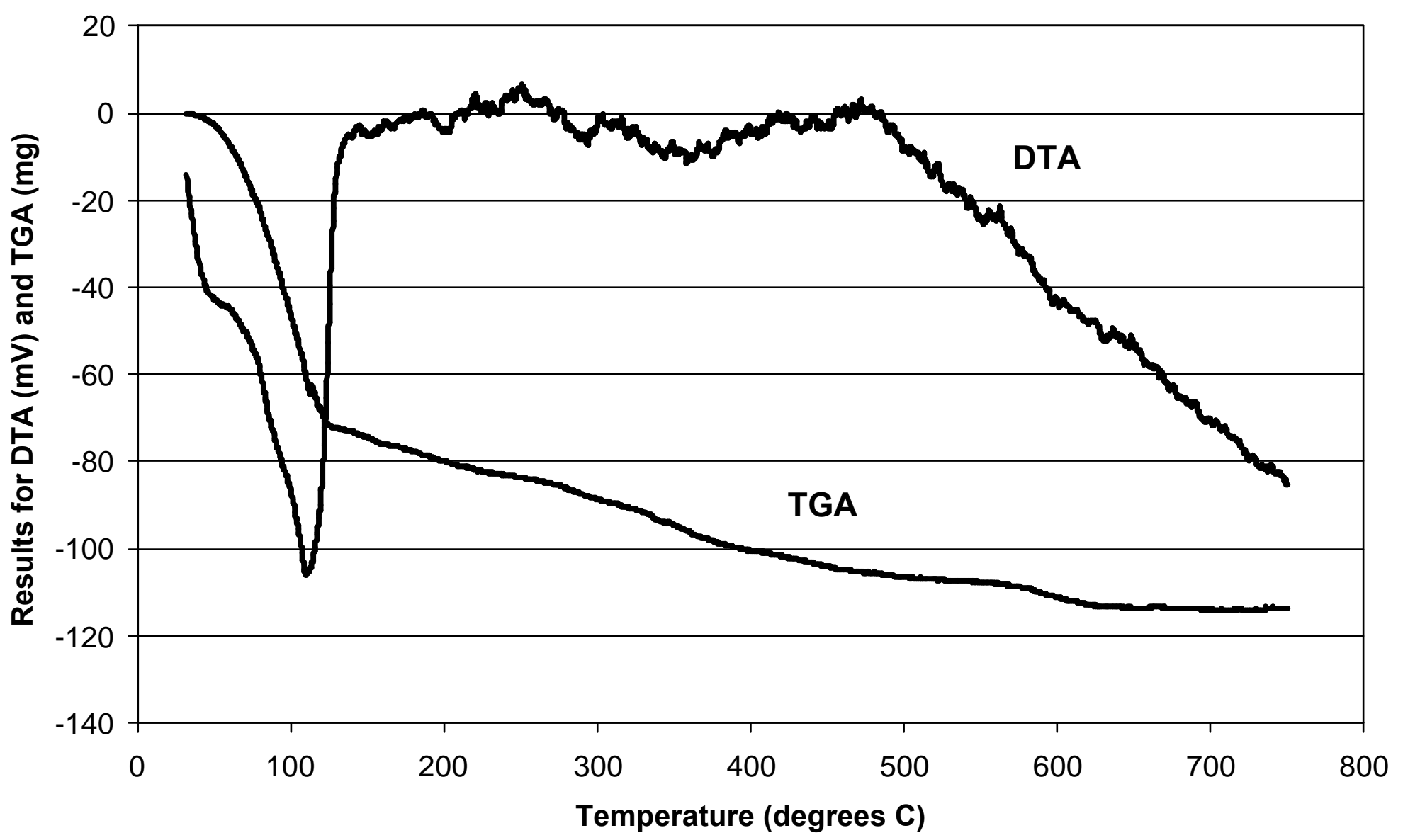

Fig. 3.4. DTA/TGA results for $\mathrm{UO}_{3}$. 
The moisture-saturated $\mathrm{U}_{3} \mathrm{O}_{8}$ sample lost $0.96 \%(0.97 \%)^{*}$ of its weight after being heated at $120^{\circ} \mathrm{C}$ overnight, then reached $1.40 \%(1.43 \%)^{*}$ weight loss after being heated at $400^{\circ} \mathrm{C}$ overnight, and finally reached a total weight loss of $1.65 \%(1.68 \%)^{*}$ after being heated at $650^{\circ} \mathrm{C}$ for another $24 \mathrm{~h}$. The drying rate at $150^{\circ} \mathrm{C}$ of such a sample in the TGA system, where the sample was inserted and then heated quickly to a holding temperature of $150^{\circ} \mathrm{C}$, is shown in Fig. 3.5. After $100 \mathrm{~min}$ at this temperature, a $0.61 \%$ weight loss was observed, after which no further weight change occurred. The TGA of this moisture-saturated sample gave a total weight loss of $1.74 \%(1.77 \%)^{*}$ at a heating rate of $60^{\circ} \mathrm{C} / \mathrm{h}$ and $1.62 \%(1.64)^{*}$ at $120^{\circ} \mathrm{C} / \mathrm{h}$. Typical DTA/TGA analyses of two different $\mathrm{U}_{3} \mathrm{O}_{8}$ samples are shown in Fig. 3.6, with the most significant change being the moisture loss between 100 and $150^{\circ} \mathrm{C}$. The drift in the TGA line beyond $150^{\circ} \mathrm{C}$ is typical for TGA analyses on this system. The sample showing the larger weight loss was run to verify the changes seen in the other sample and agrees very well with the former. Both of these samples were loaded to approximately $5 \mathrm{wt} \%$ with moisture in the $97.5 \%$ humidity. The DTA shows a small inflection at $100-120^{\circ} \mathrm{C}$, which is consistent with the major change in the TGA lines. The gradual downward drift of the DTA line beyond $400^{\circ} \mathrm{C}$ is another artifact typical of this system and is not indicative of any changes in the sample itself. Table 3.1 summarizes the results from the water sorption experiments.

\subsection{GAMMA RADIOLYSIS EXPERIMENTS}

Irradiation experiments were conducted for a number of uranium oxide samples using either the ORNL ${ }^{60}$ Co source or HFIR SNF elements. Table 3.2 provides a summary of the irradiation experiments performed. The results obtained from the radiolysis experiments are presented in Sects. 3.2.1 through 3.2.3.

\subsubsection{Pressure Measurements}

Pressure within the sample containers was monitored throughout the irradiations, and the pressure data from each of the experiments are shown in Figs. 3.7-3.18. The pressure and gas yield (millimoles of gas per gram of sample) are plotted as a function of dose in each of the figures. The gas yield was calculated using the ideal gas law. 


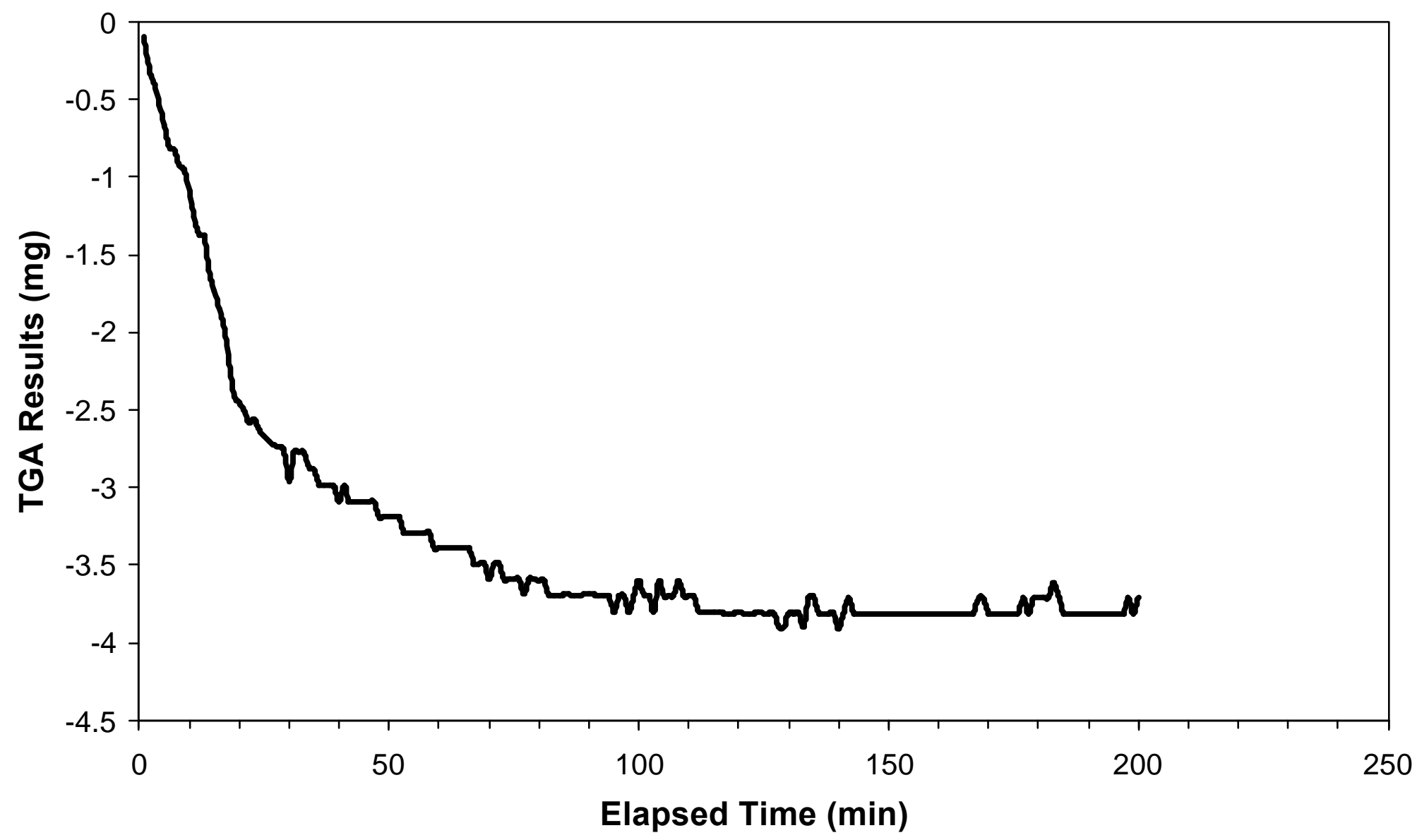

Fig. 3.5. Weight loss for $\mathrm{U}_{3} \mathrm{O}_{8}$ on heating at a fixed temperature of $150^{\circ} \mathrm{C}$. 


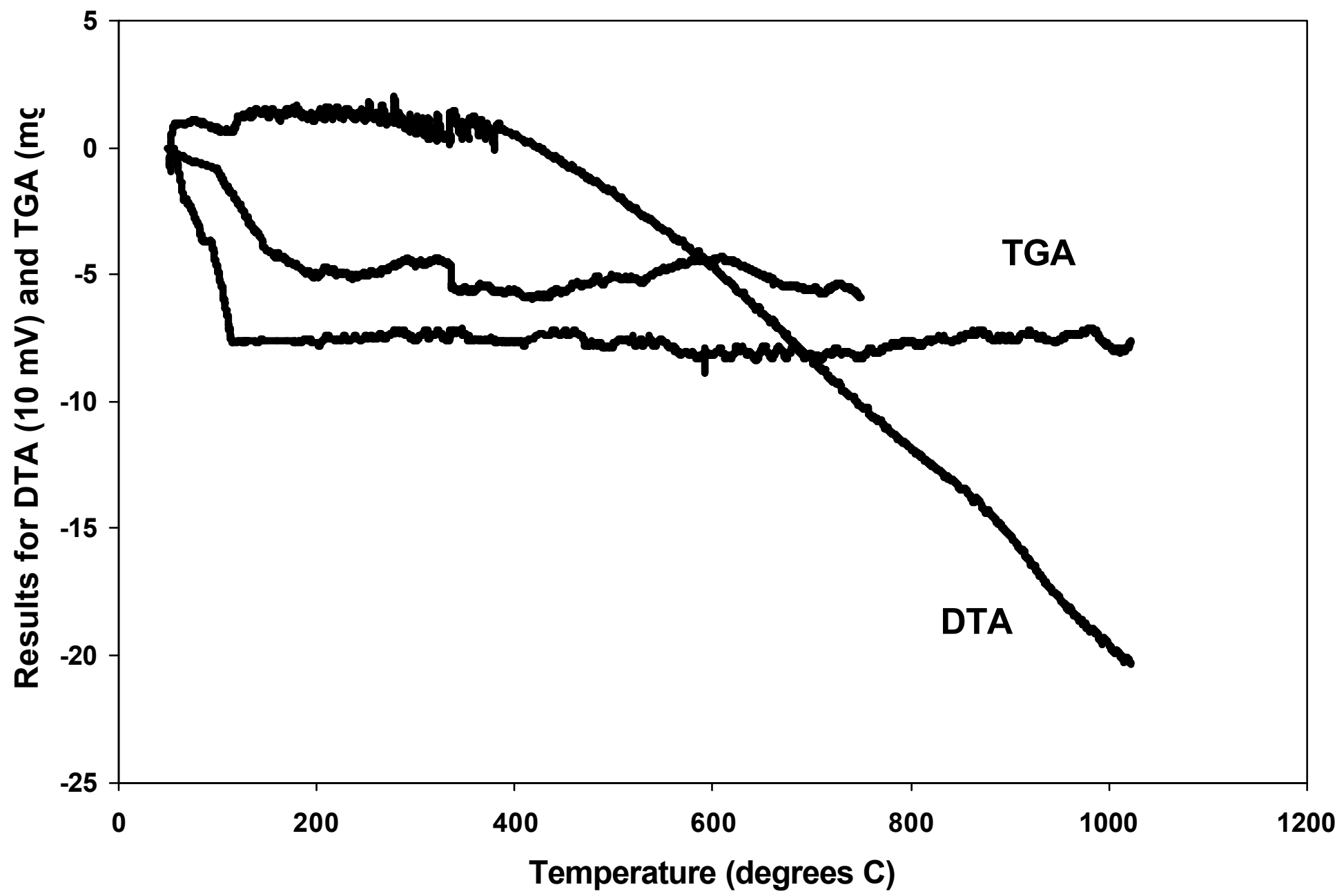

Fig. 3.6. DTA/TGA of moisture-saturated $\mathrm{U}_{3} \mathrm{O}_{8}$ in argon. 
Table 3.1. Humidification/Drying tests of uranium oxides

\begin{tabular}{|c|c|c|c|c|c|c|c|}
\hline \multirow{3}{*}{ Compound } & \multirow{3}{*}{$\begin{array}{l}\text { Relative } \\
\text { humidity } \\
(\%)\end{array}$} & \multirow{3}{*}{$\begin{array}{l}\text { Weight } \\
\text { gain }(\%)\end{array}$} & \multicolumn{5}{|c|}{ Weight loss $(\%)^{a}$} \\
\hline & & & \multicolumn{3}{|c|}{ Oven drying } & \multicolumn{2}{|c|}{ TGA } \\
\hline & & & $\begin{array}{l}120 \mathrm{EC} \\
(16 \mathrm{~h})^{b}\end{array}$ & $\begin{array}{l}400 \mathrm{EC} \\
(24 \mathrm{~h})^{b}\end{array}$ & $\begin{array}{l}650 \mathrm{EC} \\
(24 \mathrm{~h})^{b}\end{array}$ & $60 \mathrm{EC} / \mathrm{h}$ & $120 \mathrm{EC} / \mathrm{h}$ \\
\hline \multirow[t]{3}{*}{$\mathrm{UO}_{3}$} & 97.5 & 33 & 25.5 & 32.6 & 33.8 & 32.8 & 27.2 \\
\hline & 97.5 & 23 & & & & & \\
\hline & 70 & 14 & & & & & \\
\hline \multirow[t]{3}{*}{$\mathrm{U}_{3} \mathrm{O}_{8}$} & 97.5 & 1.6 & 0.97 & 1.43 & 1.68 & 1.77 & 1.64 \\
\hline & 97.5 & 8.0 & & & & & \\
\hline & 70 & 4.0 & & & & & \\
\hline $\mathrm{UO}_{2}$ & 97.5 & 0 & & & & 0 & \\
\hline
\end{tabular}

${ }^{a}$ Weight loss based on original dry sample. See description in text.

${ }^{b}$ Time sample was held at indicated temperature. 
Table 3.2. Summary of irradiation experiments performed

\begin{tabular}{|c|c|c|c|c|c|}
\hline Container & Material & $\begin{array}{c}\text { Mass } \\
(\mathrm{g})\end{array}$ & $\begin{array}{c}\text { Initial } \\
\text { atmosphere }\end{array}$ & $\begin{array}{l}\text { Irradiation } \\
\text { source }\end{array}$ & $\begin{array}{c}\text { Total } \\
\text { dose }(\mathrm{rad})^{c}\end{array}$ \\
\hline $\mathrm{S}-7^{b}$ & $\mathrm{U}_{3} \mathrm{O}_{8}$ dry & 12.2 & Helium & ${ }^{60} \mathrm{Co}$ & $1.8 \times 10^{8}$ \\
\hline S-15 & $\mathrm{U}_{3} \mathrm{O}_{8}$ with $0.7 \mathrm{wt} \% \mathrm{H}_{2} \mathrm{O}$ & 7.1 & Air/Heliumf & ${ }^{60} \mathrm{Co}$ & $2.5 \times 10^{8}$ \\
\hline S-17 & $\begin{array}{l}\mathrm{U}_{3} \mathrm{O}_{8} \text { dry with } 1.4 \mathrm{wt} \% \\
\text { fluoride }\end{array}$ & 8.0 & Helium & ${ }^{60} \mathrm{Co}$ & $2.2 \times 10^{8}$ \\
\hline S-19 & $\mathrm{U}_{3} \mathrm{O}_{8}$ with 0.89 wt $\% \mathrm{H}_{2} \mathrm{O}$ & 11.22 & Air/Heliumf & ${ }^{60} \mathrm{Co}$ & $2.2 \times 10^{8}$ \\
\hline HFIR-2 & $\begin{array}{l}\mathrm{U}_{3} \mathrm{O}_{8} \text { dry with } 1.4 \mathrm{wt} \% \\
\text { fluoride }\end{array}$ & 29.963 & Helium & HFIR SNF & $3.0 \times 10^{10 d}$ \\
\hline HFIR-3 & $\begin{array}{l}\mathrm{U}_{3} \mathrm{O}_{8} \text { with } 1.4 \mathrm{wt} \% \text { fluoride } \\
\text { and } 9.1 \mathrm{wt} \% \mathrm{H}_{2} \mathrm{O}\end{array}$ & 32.963 & Air/Heliume & HFIR SNF & $4.5 \times 10^{10 d}$ \\
\hline HFIR-5 & $\mathrm{U}_{3} \mathrm{O}_{8}$ with $1.04 \mathrm{wt} \% \mathrm{H}_{2} \mathrm{O}$ & 30.0 & Air/Heliume & HFIR SNF & $8.2 \times 10^{10 d}$ \\
\hline HFIR-6-1 & $\begin{array}{l}\mathrm{U}_{3} \mathrm{O}_{8} \text { with } 5 \mathrm{wt} \% \mathrm{Gd}_{2} \mathrm{O}_{3} \\
\text { and } 1.48 \text { wt } \% \mathrm{H}_{2} \mathrm{O}\end{array}$ & 9.6 & Air & HFIR SNF & $3.3 \times 10^{10 d}$ \\
\hline HFIR-6-2 & $\mathrm{U}_{3} \mathrm{O}_{8}$ with 6 wt $\% \mathrm{H}_{2} \mathrm{O}$ & 14.2 & Air & HFIR SNF & $3.2 \times 10^{10 d}$ \\
\hline S-14 & $\begin{array}{l}\mathrm{UO}_{3} \mathrm{GH}_{2} \mathrm{O} \text { with } 1.8 \text { wt } \% \\
\mathrm{H}_{2} \mathrm{O}\end{array}$ & 5.6 & Air/Heliumf & ${ }^{60} \mathrm{Co}$ & $2.5 \times 10^{8}$ \\
\hline S-18 & $\begin{array}{l}\mathrm{UO}_{3} \mathrm{CH}_{2} \mathrm{O} \text { with } 2.47 \text { wt } \% \\
\text { sorbed } \mathrm{H}_{2} \mathrm{O}\end{array}$ & 9.95 & Air/Heliumf & ${ }^{60} \mathrm{Co}$ & $2.2 \times 10^{8}$ \\
\hline HFIR-4 & $\mathrm{UO}_{3} \mathrm{OH}_{2} \mathrm{O}$ & 30 & Air/Heliume & HFIR SNF & $3.7 \times 10^{10 d}$ \\
\hline HFIR-6-3 & $\mathrm{UO}_{3}$ & 17.9 & Air & HFIR SNF & $3.3 \times 10^{10 d}$ \\
\hline
\end{tabular}

${ }^{a} \mathrm{~W}-\mathrm{h} / \mathrm{g}=3.6 \times 10^{8} \mathrm{rad}$.

${ }^{b}$ Not instrumented for pressure.

${ }^{c}$ Sample container was leak checked with helium prior to opening for loading. Although the sample was loaded in air, some of the helium was still trapped within the rig. Therefore, the initial atmosphere was air/helium.

${ }^{d}$ Dose based on $0.93-\mathrm{MeV}$ average gamma energy.

${ }^{e}$ Sample was loaded in air but was backfilled with helium to $1.7 \mathrm{~atm}(10 \mathrm{psig})$ before delivery to HFIR for installation-a HFIR operations requirement that the pressure in the container be greater than the SNF pool pressure. 


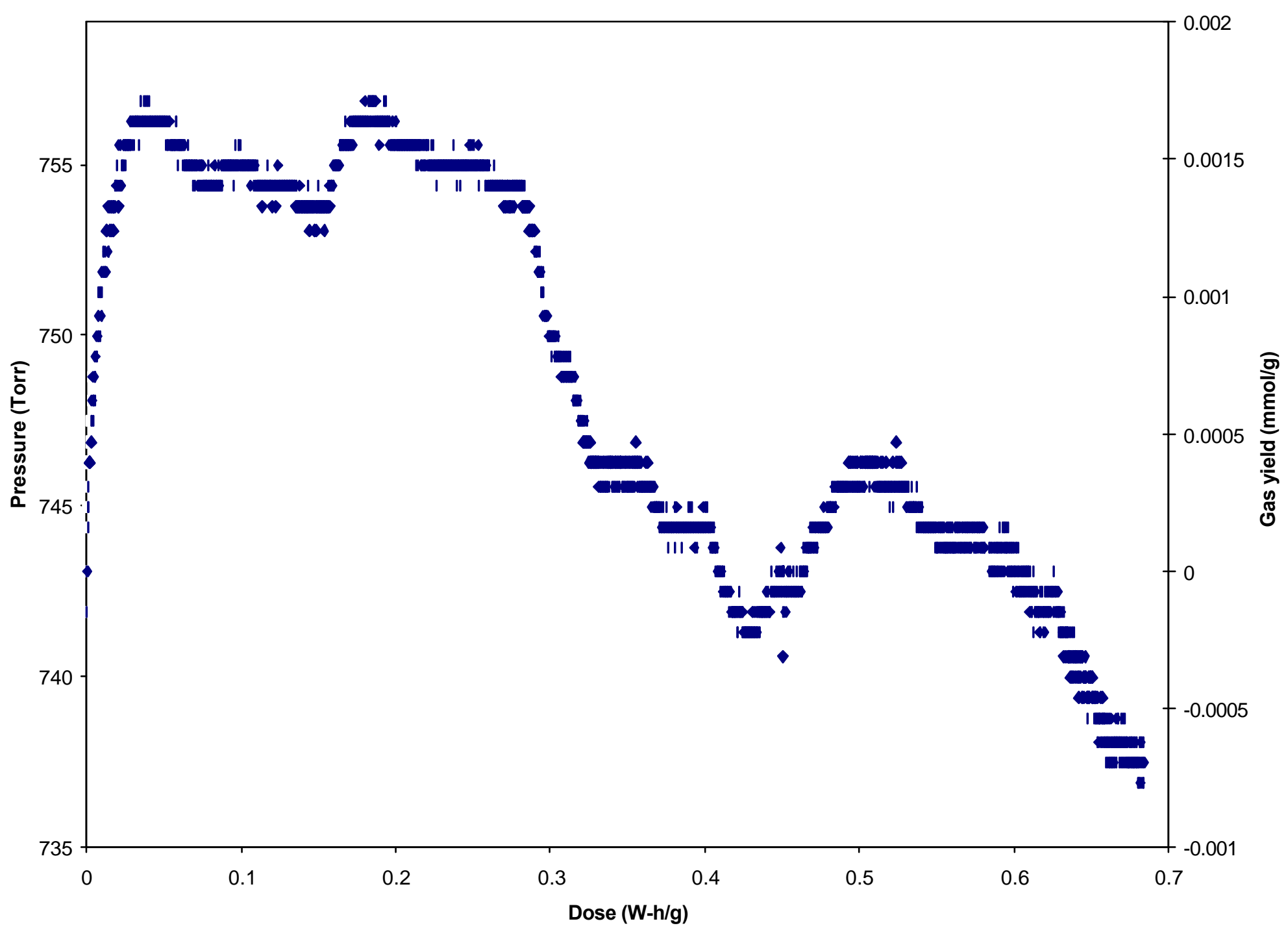

Fig. 3.7. Pressure and gas yield as a function of dose for sample $\mathrm{S}-15\left({ }^{60} \mathrm{Co}\right.$-irradiated $\mathrm{U}_{3} \mathrm{O}_{8}$ with 0.7 wt $\% \mathrm{H}_{2} \mathrm{O}$, loaded in air/helium). 


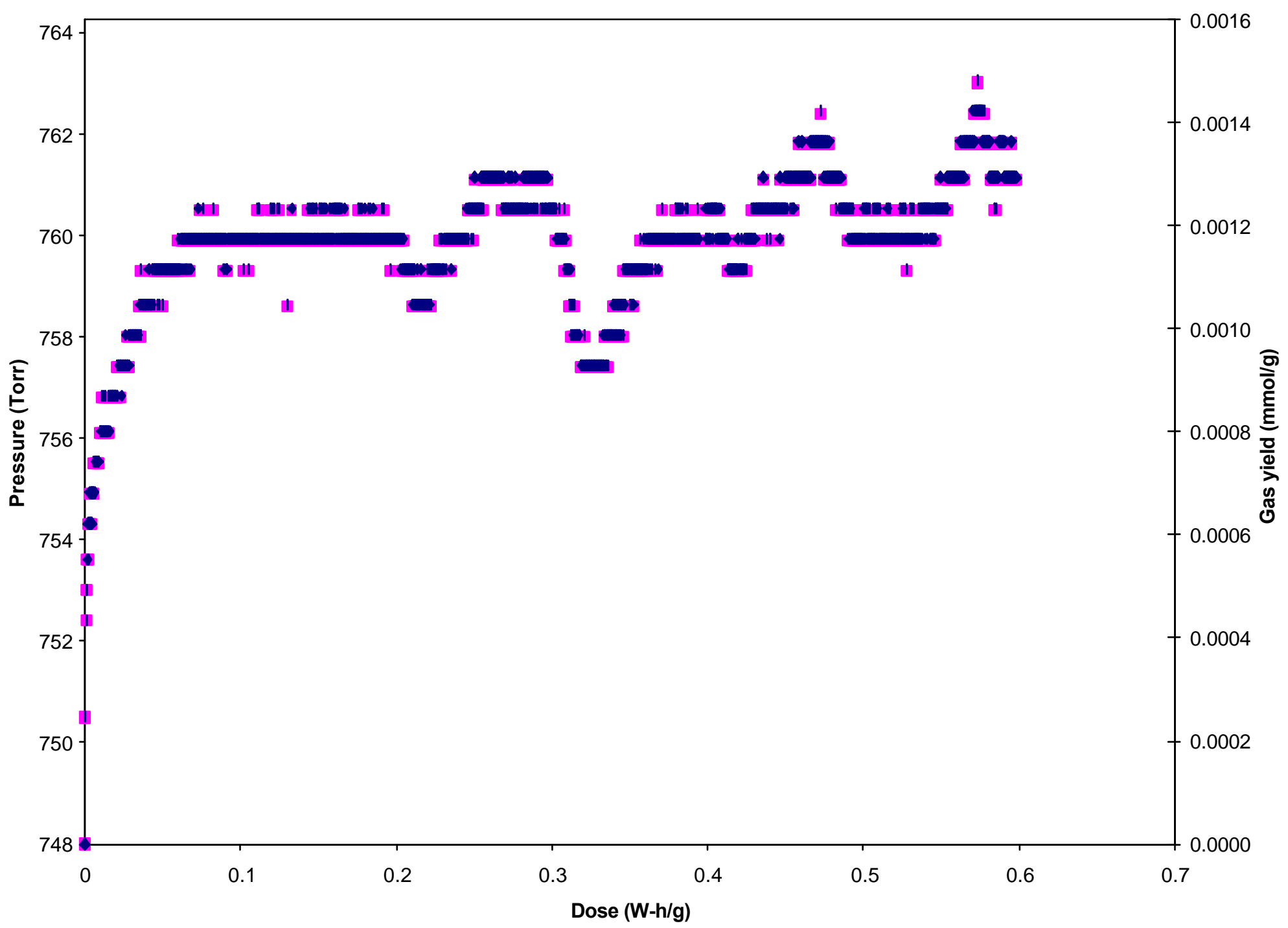

Fig. 3.8. Pressure and gas yield as a function of dose for sample S-17 $\left({ }^{60} \mathrm{Co}\right.$-irradiated $\mathrm{U}_{3} \mathrm{O}_{8}$ with 1.4 wt $\%$ fluoride, loaded in helium). 


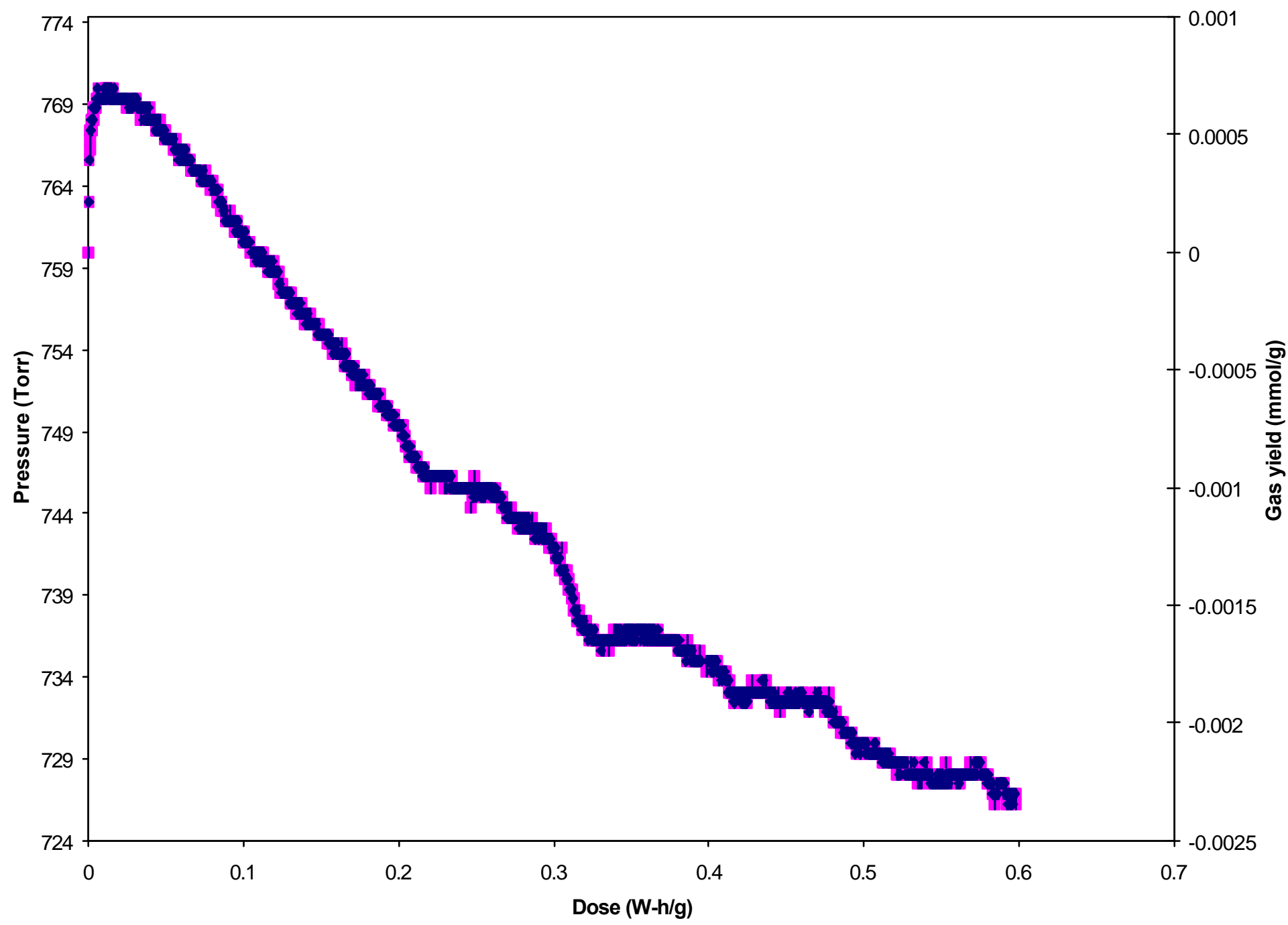

Fig. 3.9. Pressure and gas yield as a function of dose for sample $\mathrm{S}-19\left({ }^{60} \mathrm{Co}\right.$-irradiated $\mathrm{U}_{3} \mathrm{O}_{8}$ with 0.89 wt \% $\mathrm{H}_{2} \mathrm{O}$, loaded in air/helium). 


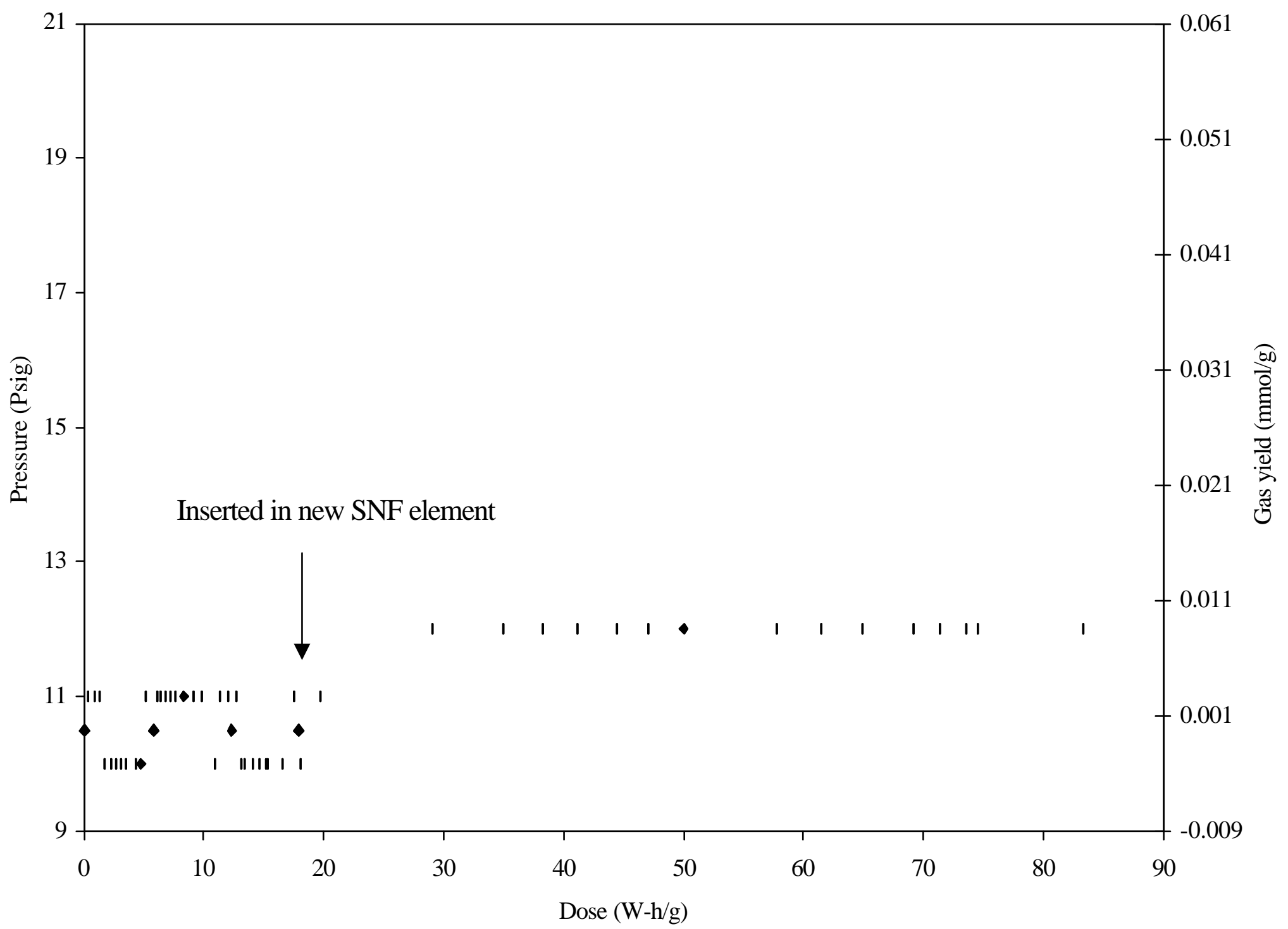

Fig. 3.10. Pressure and gas yield as a function of dose for sample HFIR-2 (HFIR SNF-irradiated $\mathrm{U}_{3} \mathrm{O}_{8}$ with $1.4 \mathrm{wt} \%$ fluoride, loaded in helium). 


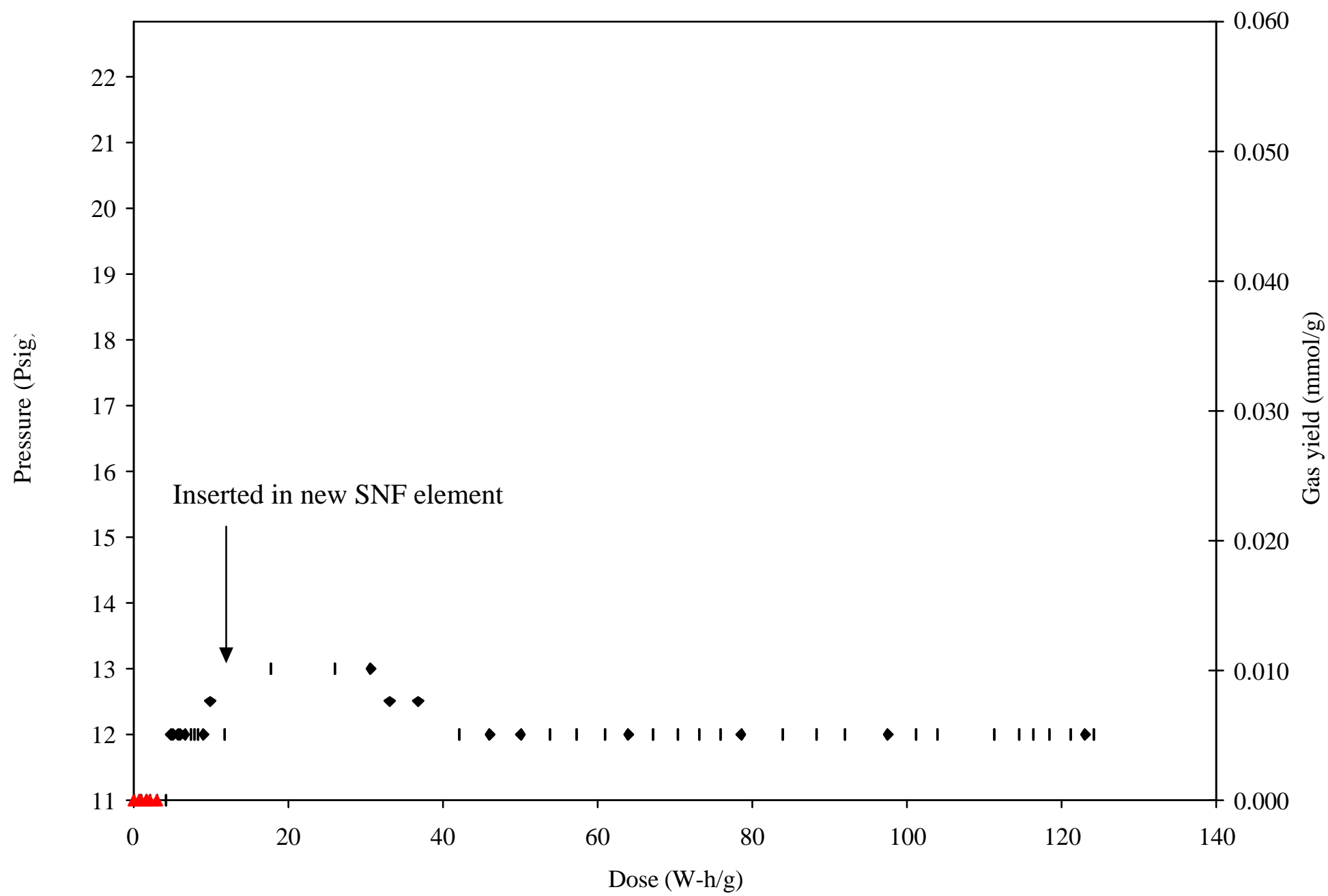

Fig. 3.11. Pressure and gas yield as a function of dose for sample HFIR-3 (HFIR SNF-irradiated $\mathrm{U}_{3} \mathrm{O}_{8}$ with $1.4 \mathrm{wt} \%$ fluoride and $9.1 \mathrm{wt} \% \mathrm{H}_{2} \mathrm{O}$ loaded in air/helium). 


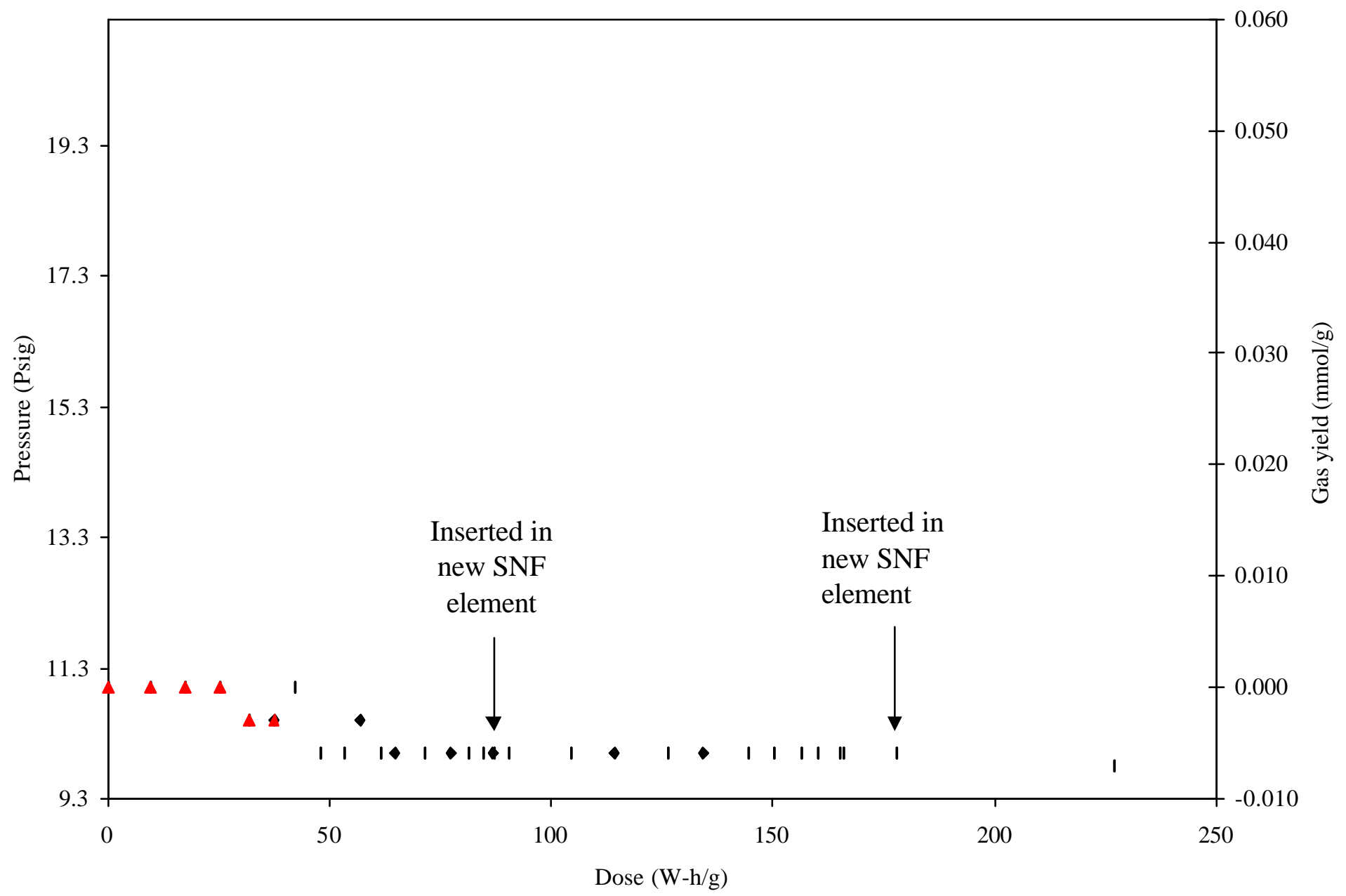

Fig. 3.12. Pressure and gas yield as a function of dose for sample HFIR-5 (HFIR SNF-irradiated $\mathrm{U}_{3} \mathrm{O}_{8}$ with $1.04 \mathrm{wt} \% \mathrm{H}_{2} \mathrm{O}$, loaded in air/helium). 


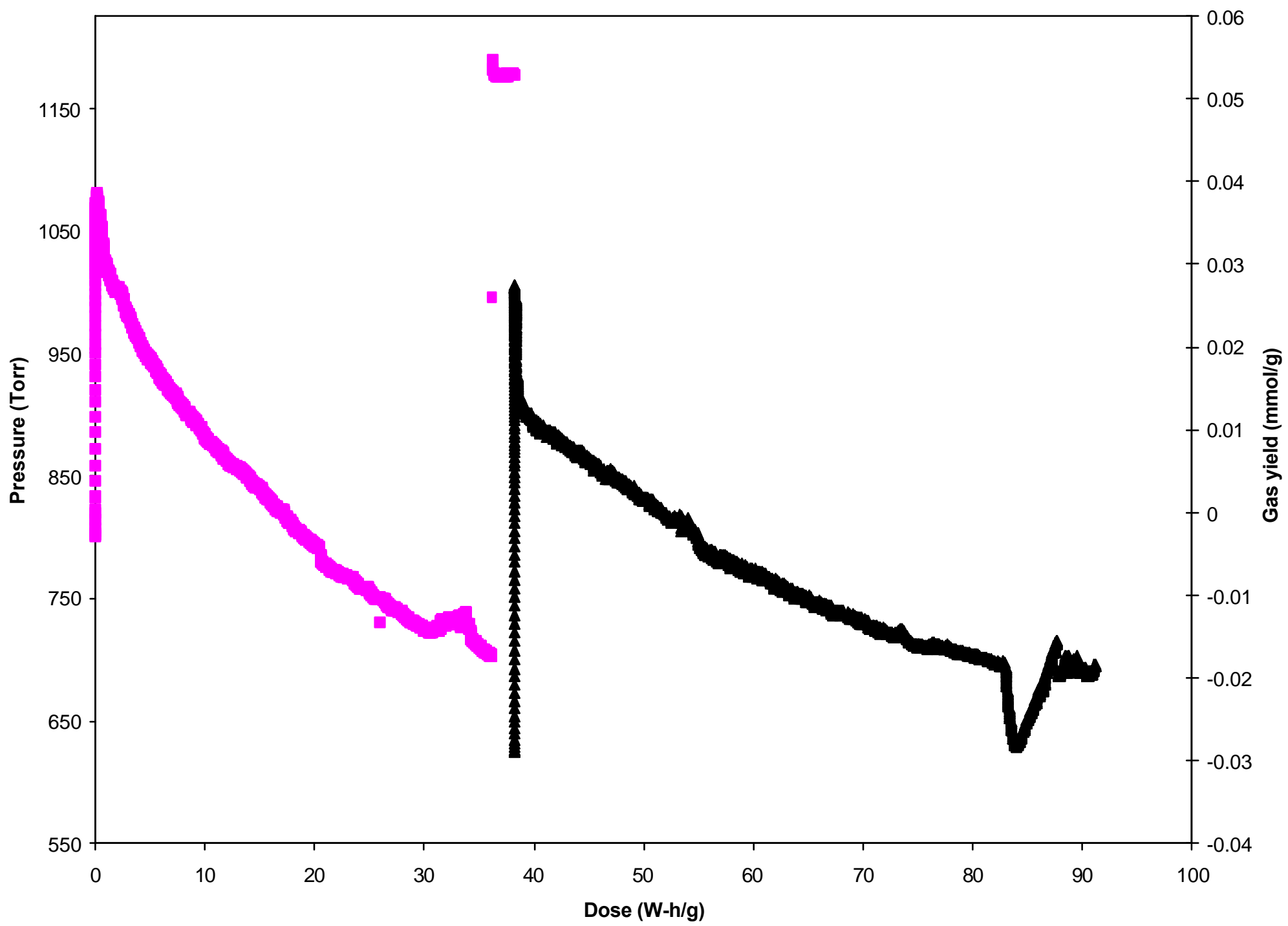

Fig. 3.13. Pressure and gas yield as a function of dose for sample HFIR-6-1 (HFIR SNF-irradiated $\mathrm{U}_{3} \mathrm{O}_{8}$ with $5 \mathrm{wt} \% \mathrm{Gd}_{2} \mathrm{O}_{3}$ and $1.48 \mathrm{wt} \% \mathrm{H}_{2} \mathrm{O}$, loaded in air). (Vertical discontinuities represent SNF element changes. See text for full explanation.) 


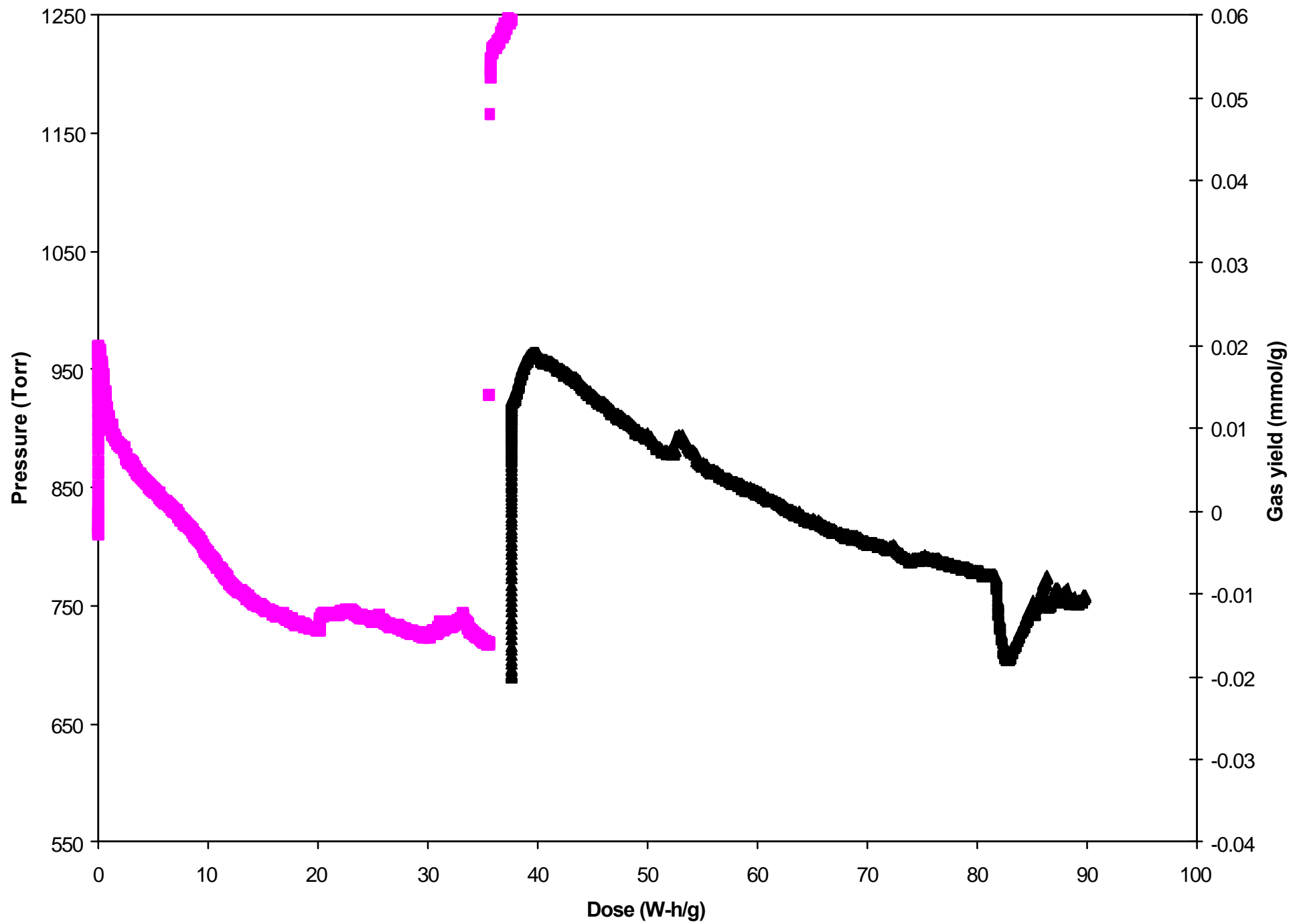

Fig. 3.14. Pressure and gas yield as a function of dose for sample HFIR-6-2 (HFIR SNF-irradiated $\mathrm{U}_{3} \mathrm{O}_{8}$ with $6 \mathrm{wt} \% \mathrm{H}_{2} \mathrm{O}$, loaded in air). (Vertical discontinuities represent SNF element changes. See text for full explanation.) 


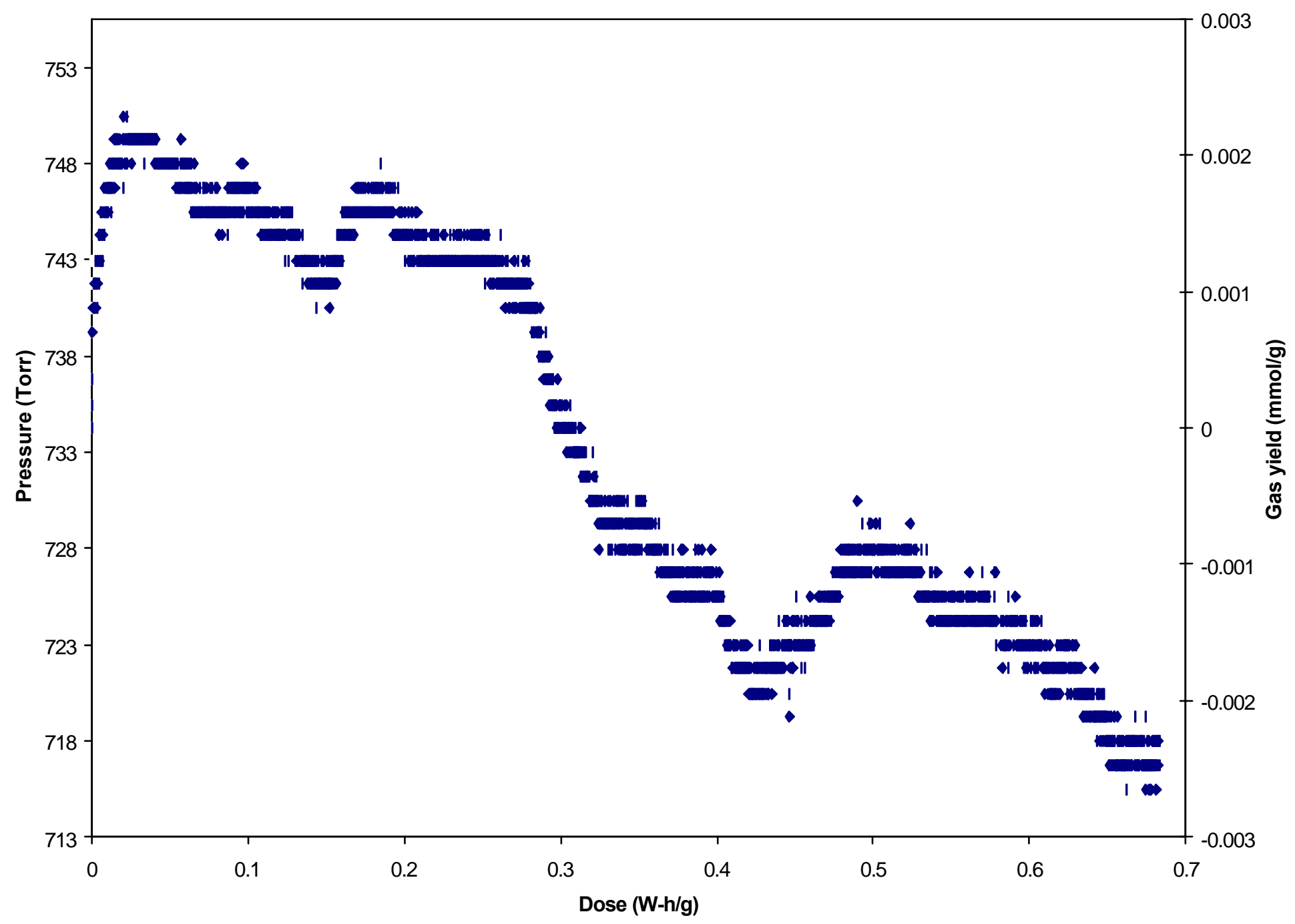

Fig. 3.15. Pressure and gas yield as a function of dose for sample $\mathrm{S}-14\left({ }^{60} \mathrm{Co}\right.$-irradiated $\mathrm{UO}_{3} \bullet x \mathrm{H}_{2} \mathrm{O}$ with $1.8 \mathrm{wt} \% \mathrm{H}_{2} \mathrm{O}$, loaded in air/helium). 


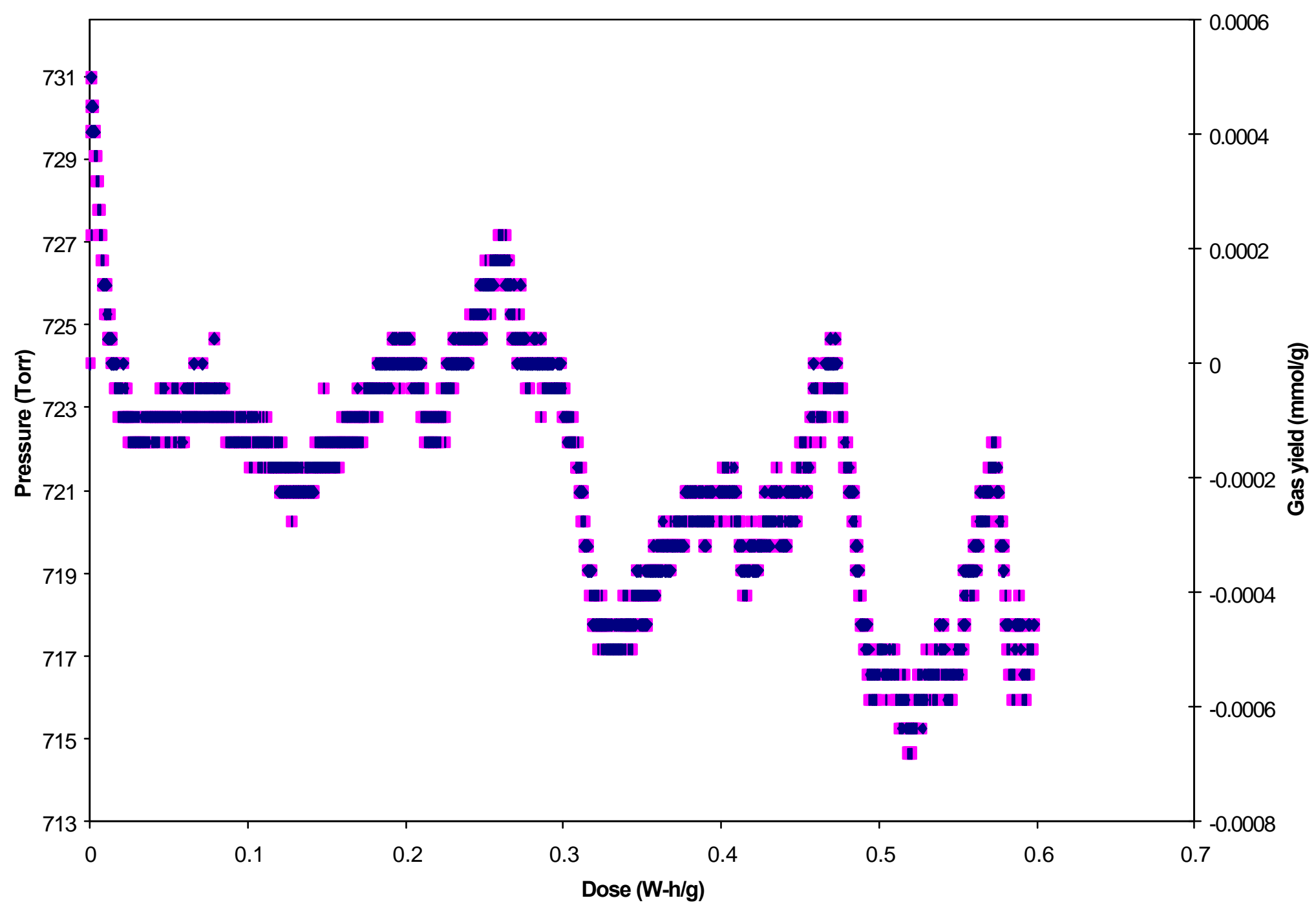

Fig. 3.16. Pressure and gas yield as a function of dose for sample $\mathrm{S}-18\left({ }^{60} \mathrm{Co}\right.$-irradiated $\mathrm{UO}_{3} \mathrm{OH}_{2} \mathrm{O}$ with $2.47 \mathrm{wt} \%$ sorbed $\mathrm{H}_{2} \mathrm{O}$, loaded in air/helium). 
ORNL DWG 2001-03981

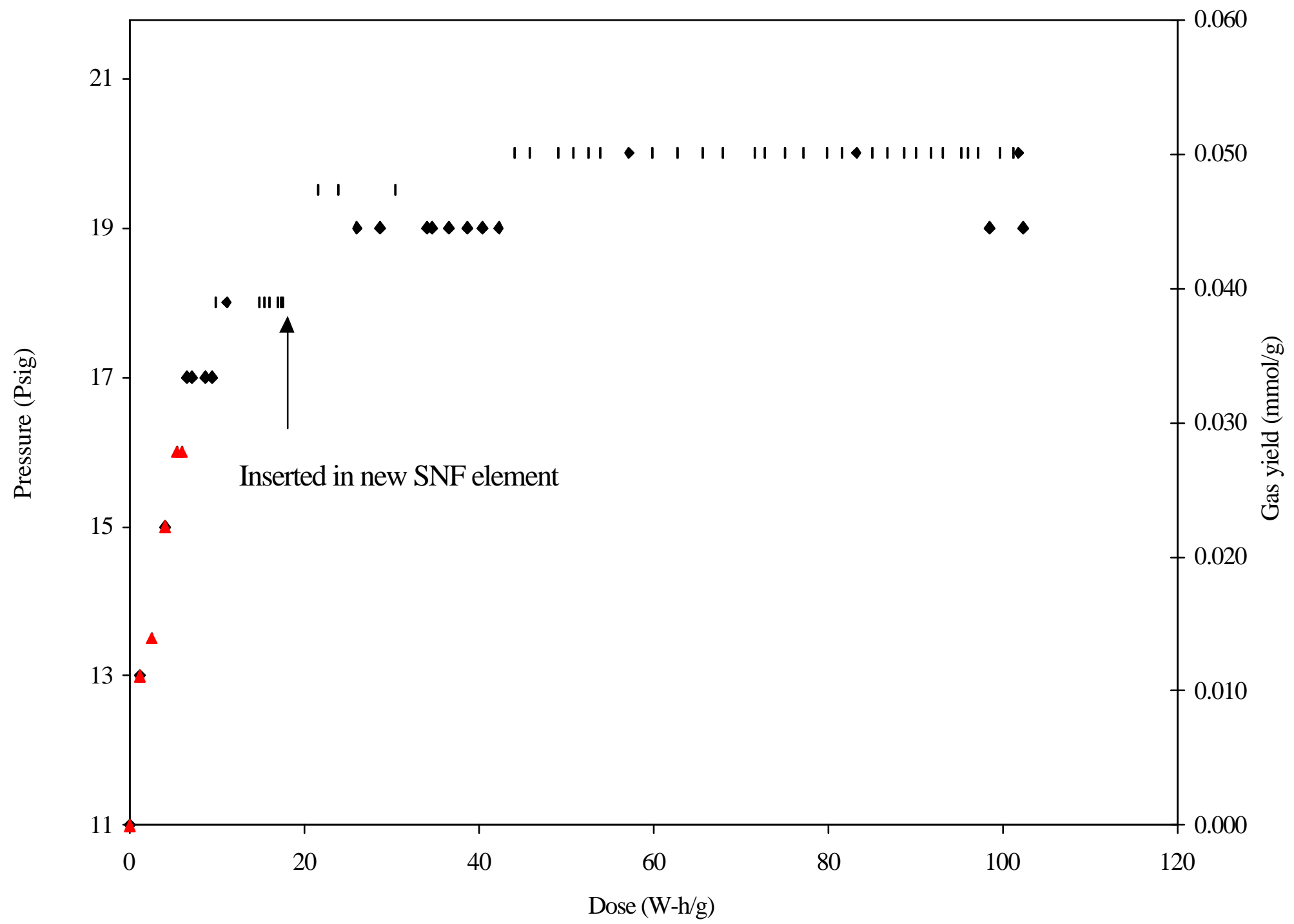

Fig. 3.17. Pressure and gas yield as a function of dose for sample HFIR-4 (HFIR SNF-irradiated $\mathrm{UO}_{3} \mathrm{OH}_{2} \mathrm{O}$, loaded in air/helium). 


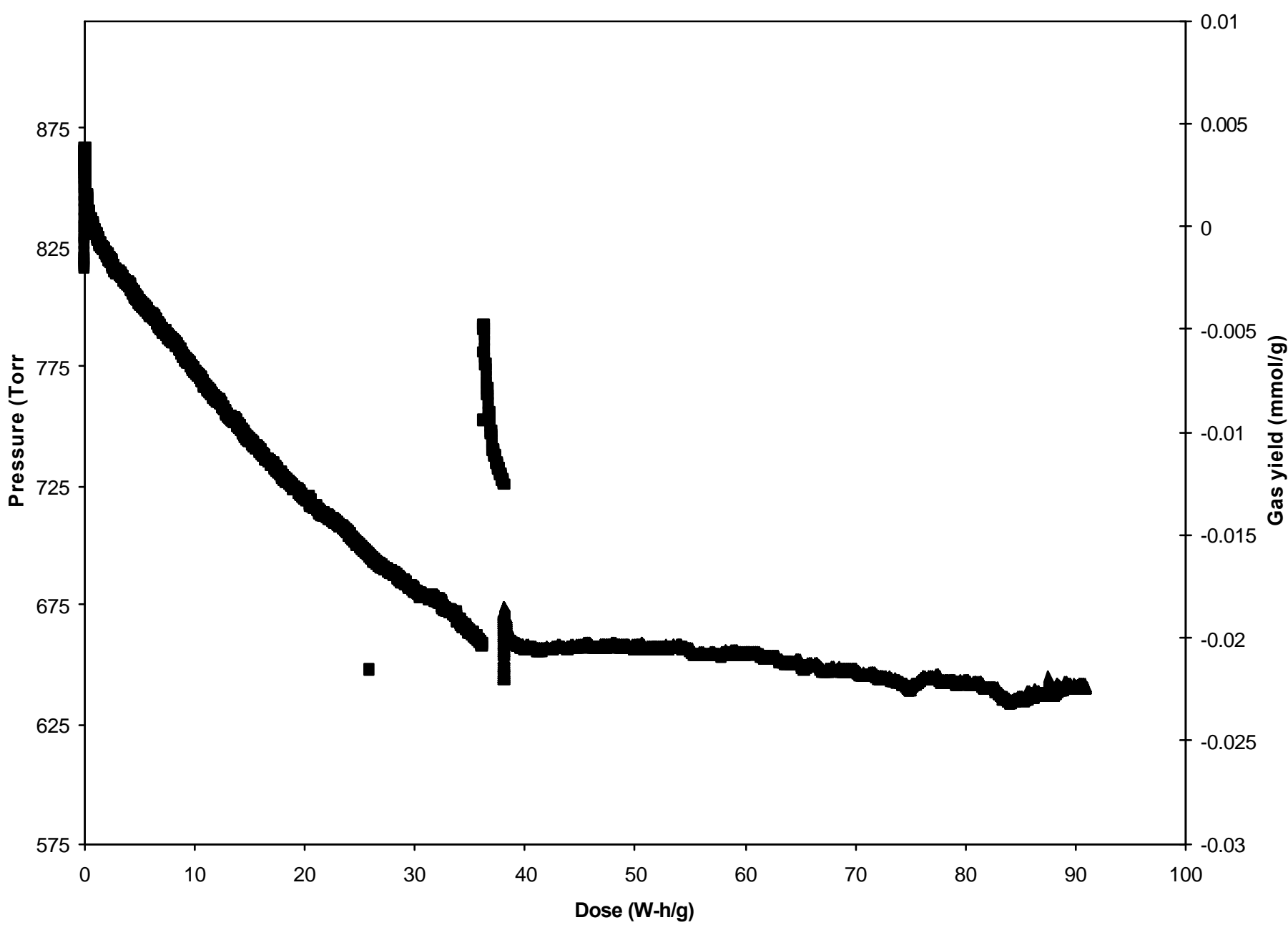

Fig. 3.18. Pressure and gas yield as a function of dose for sample HFIR-6-3 (HFIR SNF-irradiated $\mathbf{U O}_{3}$, loaded in air). (Vertical discontinuities represent SNF element changes. See text for full explanation.) 
Container temperatures in the ${ }^{60} \mathrm{Co}$ irradiator were measured to be about $28^{\circ} \mathrm{C}$. The temperature in the HFIR small-vessel irradiations was assumed to be $40^{\circ} \mathrm{C}$ - the temperature at which the SNF pool water is maintained. For the HFIR multiple-vessel irradiations, the temperature was estimated from the change in the pressure in the outer vessel that surrounded the sample container. This temperature typically ranged from 50 to $60^{\circ} \mathrm{C}$, with several short transients upon insertion of the experiment into a fresh element or because of lowering of the pool temperature by HFIR operations personnel. Figure 3.19 shows the estimated temperature profile for containers HFIR-6-1, HFIR-6-2, and HFIR-6-3.

Figures 3.7 through 3.14 present results from the irradiation experiments for the $\mathrm{U}_{3} \mathrm{O}_{8}$ samples. Each of these experiments showed only a minor increase in pressure, with most exhibiting an overall pressure decrease. All of the $\mathrm{U}_{3} \mathrm{O}_{8}$ samples that had sorbed water and were loaded in air (Figs. 3.7, 3.9, 3.11-3.14) showed a pressure decrease. The two samples that had no sorbed water and that were loaded in helium showed only a small pressure increase, which could be attributed to the heating of the container.

Figures 3.13 and 3.14 both present results from the multiple-irradiation-container experiments. For these samples, a rapid initial pressure increase was seen, followed by a steady pressure decrease. After a dose of about $38 \mathrm{~W}-\mathrm{h} / \mathrm{g}$ was reached, these samples were placed in a freshly discharged SNF element ( $\sim 5 \mathrm{~d}$ since discharge from the reactor). The heat generated by this element caused the pressure in the sample containers and the outer vessel to increase rapidly. Because the pressure in one of the containers was greater than a predetermined safety-action level, the experiment was removed from the SNF element. After the element cooled for an additional $12 \mathrm{~d}$, the experiment was reinserted. Again, the pressure initially increased but then began to go down. For both HFIR-6-1 and HFIR-6-2, the pressure went to vacuum.

Finally, note the pressure dip at a dose of about $80 \mathrm{~W}$-h/g in Figs. 3.13 and 3.14. This dip was caused by changing of the SNF pool temperature for maintenance activities, which resulted in a lowering of the temperature to about $32^{\circ} \mathrm{C}$ (Fig. 3.19).

Results for the irradiation experiments with $\mathrm{UO}_{3} \bullet x \mathrm{H}_{2} \mathrm{O}$ are shown in Figs. 3.15-3.18. Each of these experiments, except for HFIR-4, showed a pressure decrease. In the case of HFIR-4, the pressure increased about 10 psi to a plateau. 
ORNL DWG 2001-04208

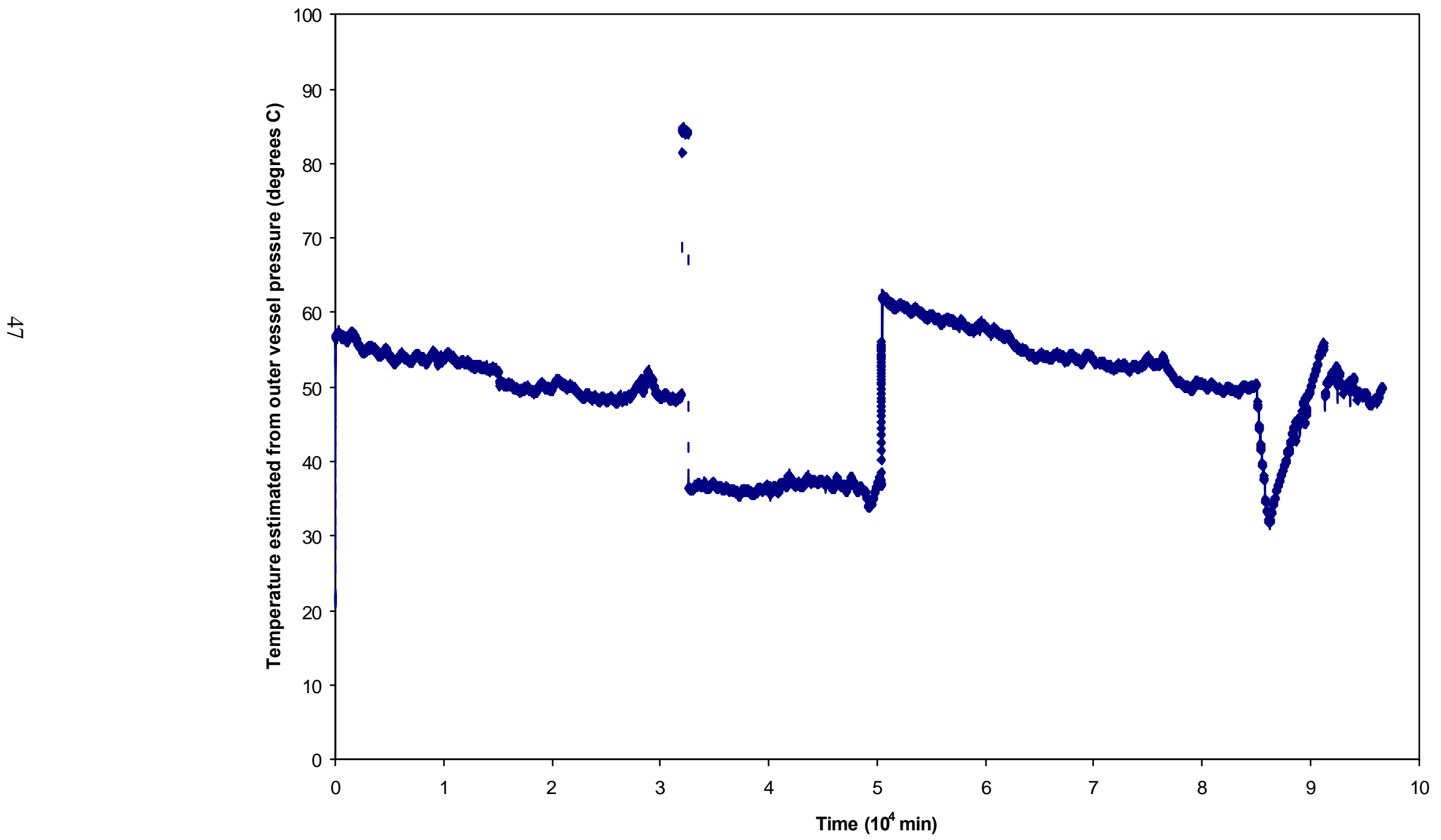

Fig. 3.19. Estimated temperature as a function of time for vessels HFIR-6-1, HFIR-6-2, and HFIR-6-3. 
Figure 3.18 shows results from the multiple-irradiation-container experiment. This sample (HFIR-6-3) was irradiated along with HFIR-6-1 and HFIR-6-2, and the pressure fluctuations observed were caused by the same events described for Figs. 3.13 and 3.14 .

Figure 3.20 clearly depicts the effect of radiation on samples HFIR-6-1, HFIR-6-2, and HFIR-6-3. This plot shows the sample pressure as a function of time. Note that when the samples are inserted into a SNF element, there is an initial pressure increase, followed by a steady decrease. During the time the samples are out of the SNF element, the pressure is steady. Then when the samples are reinserted into the SNF element, an initial pressure increase is observed, followed by a pressure decrease.

\subsubsection{Gas Analyses}

Results from the gas analysis of the $\mathrm{U}_{3} \mathrm{O}_{8}$ samples are presented in Table 3.3, while those from the gas analysis of the $\mathrm{UO}_{3} \bullet x \mathrm{H}_{2} \mathrm{O}$ samples are presented in Table 3.4.

For the samples loaded in air, some insight into the radiolytic effects on the samples can be gained by comparing the final gas composition with an inert component of the air, namely argon, that acts as an internal standard. In Tables 3.5 and 3.6, such comparisons are made for the $\mathrm{U}_{3} \mathrm{O}_{8}$ and $\mathrm{UO}_{3} \bullet x \mathrm{H}_{2} \mathrm{O}$ samples, respectively. For most of the samples, the $\mathrm{O}_{2}$ is depleted while the $\mathrm{CO}_{2}$ and $\mathrm{H}_{2}$ levels are elevated. In the case of sample HFIR-3, the gas was primarily helium ( 96\%); therefore, the comparison may not be appropriate. (This sample was leak checked and backfilled with helium after loading.) A relatively large amount $(\sim 10 \mathrm{vol} \%)$ of $\mathrm{H}_{2}$ was produced by the irradiation of HFIR-4 $\left(\mathrm{UO}_{3} \cdot 2 \mathrm{H}_{2} \mathrm{O}\right)$. Small concentrations of either $\mathrm{NO}$ or $\mathrm{NO}_{x}$ were reported for many of the samples.

\subsubsection{Solids Analyses}

Several samples were analyzed by Davies-Gray titration to evaluate the valence of the uranium. ${ }^{14-16}$ Results of these analyses are summarized in Table 3.7. Sample HFIR-4 $\left(\mathrm{UO}_{3} \cdot 2 \mathrm{H}_{2} \mathrm{O}\right)$ appeared green after irradiation — changing from bright yellow. Uranium (IV) is characteristically green; however, no $\mathrm{U}(\mathrm{IV})$ was detected in the sample. Analysis of a sample from HFIR-6-3, which was $\mathrm{UO}_{3}$, also revealed no U(IV). Samples HFIR-6-1 and HFIR-6-2, which both contained $\mathrm{U}_{3} \mathrm{O}_{8}$, showed a reduced amount of $\mathrm{U}(\mathrm{IV})$ after irradiation as compared with that expected for $\mathrm{U}_{3} \mathrm{O}_{8}$. 


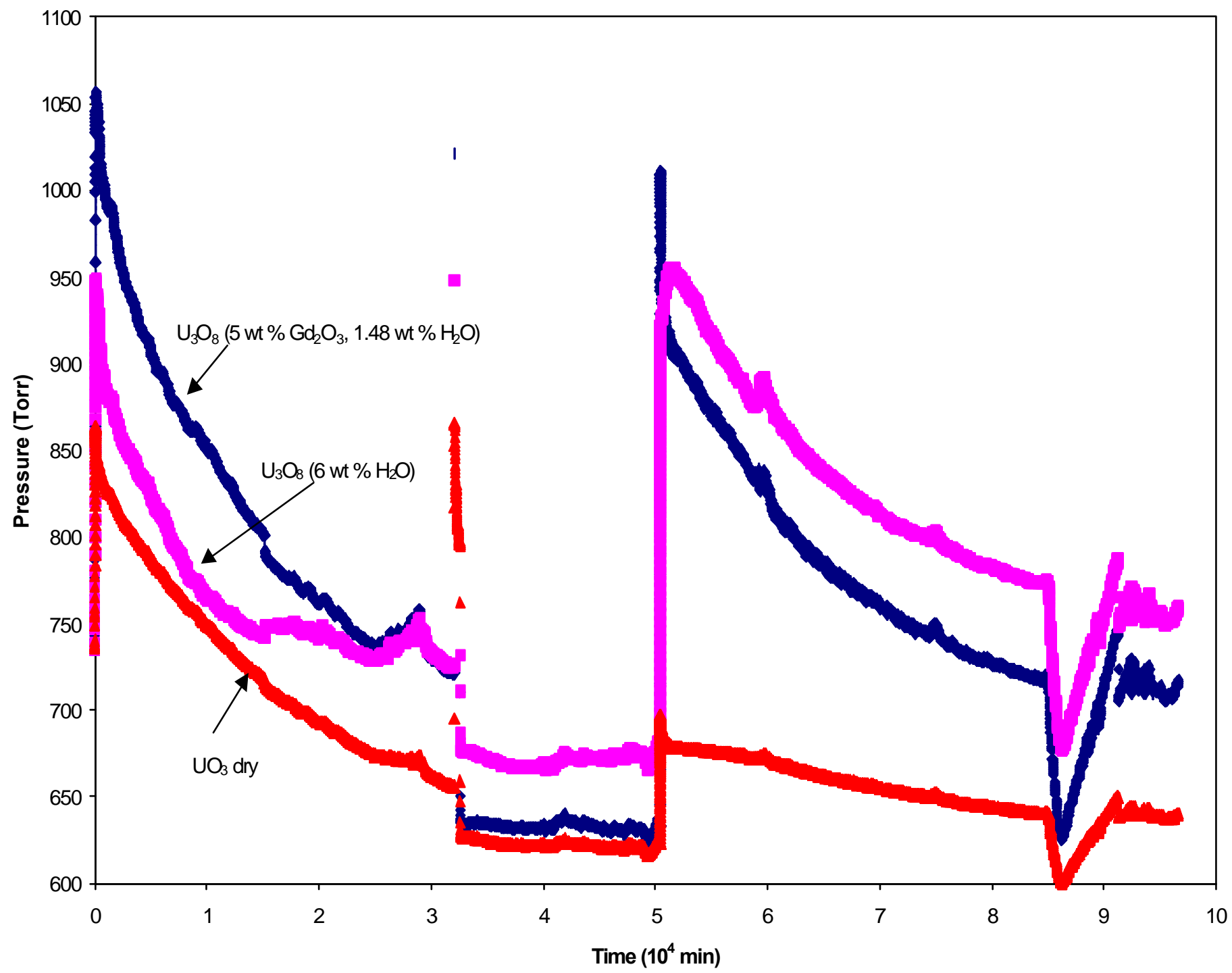

Fig. 3.20. Pressure as a function of time for samples HFIR-6-1, HFIR-6-2, and HFIR-6-3. 
Table 3.3. Results of mass spectrometric analysis (vol \%) of gas composition from $\mathrm{U}_{3} \mathrm{O}_{8}$ samples

irradiated in either the ${ }^{60}$ Co source or HFIR SNF elements

\begin{tabular}{|c|c|c|c|c|c|c|c|c|}
\hline Component & $\begin{array}{c}\mathrm{S}-7 \\
\left(\mathrm{U}_{3} \mathrm{O}_{8} \text { dry }\right)\end{array}$ & $\begin{array}{c}\mathrm{S}-15 \\
\left(\mathrm{U}_{3} \mathrm{O}_{8} \text { with }\right. \\
\left.0.7 \text { wt } \% \mathrm{H}_{2} \mathrm{O}\right)\end{array}$ & $\begin{array}{c}\mathrm{S}-17 \\
\left(\mathrm{U}_{3} \mathrm{O}_{8} \text { dry with }\right. \\
1.4 \text { wt } \% \\
\text { fluoride })\end{array}$ & $\begin{array}{c}\text { S-19 } \\
\left(\mathrm{U}_{3} \mathrm{O}_{8} \text { with } 0.89\right. \\
\left.\text { wt } \% \mathrm{H}_{2} \mathrm{O}\right)\end{array}$ & $\begin{array}{c}\text { HFIR-2 } \\
\left(\mathrm{U}_{3} \mathrm{O}_{8} \text { dry with }\right. \\
1.4 \text { wt } \% \\
\text { fluoride })\end{array}$ & $\begin{array}{c}\text { HFIR-3 } \\
\left(\mathrm{U}_{3} \mathrm{O}_{8} \text { with }\right. \\
1.4 \text { wt } \% \text { fluoride } \\
\text { and with } \\
\left.9.1 \mathrm{wt} \% \mathrm{H}_{2} \mathrm{O}\right)\end{array}$ & $\begin{array}{c}\text { HFIR-6-1 } \\
\left(\mathrm{U}_{3} \mathrm{O}_{8} \text { with }\right. \\
5 \mathrm{wt} \% \mathrm{Gd}_{2} \mathrm{O}_{3} \\
\text { and } 1.48 \mathrm{wt} \% \\
\left.\quad \mathrm{H}_{2} \mathrm{O}\right)\end{array}$ & $\begin{array}{c}\text { HFIR-6-2 } \\
\left(\mathrm{U}_{3} \mathrm{O}_{8} \text { with }\right. \\
\left.6 \text { wt } \% \mathrm{H}_{2} \mathrm{O}\right)\end{array}$ \\
\hline $\begin{array}{c}\text { Initial } \\
\text { atmosphere }\end{array}$ & Helium & Air/Helium ${ }^{a}$ & Helium & Air/Helium ${ }^{a}$ & Helium & Air/Helium ${ }^{b}$ & Air & Air \\
\hline $\mathrm{N}_{2}$ & 0.72 & 48.6 & 2.18 & 54.29 & 2.03 & 1.7 & 99.32 & 95.55 \\
\hline $\mathrm{He}$ & 99.01 & 40.22 & 96.21 & 36.7 & 96.11 & 95.64 & $<0.01$ & $<0.01$ \\
\hline $\mathrm{H}_{2}$ & $<0.01$ & 0.01 & 0.02 & 0.01 & 0.004 & 0.016 & 0.05 & 1.44 \\
\hline $\mathrm{CO}_{2}$ & 0.09 & 0.61 & 0.41 & 0.27 & 1.73 & 0.72 & 0.42 & 0.3 \\
\hline $\mathrm{Ar}$ & 0.02 & 0.57 & 0.31 & 0.64 & 0.03 & 0.04 & 1.16 & 1.12 \\
\hline $\mathrm{O}_{2}$ & 0.03 & 9.88 & 0.78 & 7.9 & 0.04 & 1.86 & 0.008 & 1.51 \\
\hline $\mathrm{HF} / \mathrm{Ar}^{2+}$ & 0.01 & 0.07 & 0.06 & 0.12 & 0.005 & $<0.001$ & $<0.01$ & $<0.01$ \\
\hline $\mathrm{F}_{2}$ & & $<0.01$ & $<0.001$ & $<0.001$ & & $<0.001$ & $<0.01$ & $<0.01$ \\
\hline $\mathrm{CH}_{4}$ & 0.01 & & 0.0003 & 0.004 & $<0.001$ & & 0.005 & 0.007 \\
\hline $\mathrm{CF}_{4}$ & 0.02 & $<0.01$ & & & $<0.001$ & $<0.01$ & & \\
\hline $\mathrm{CO}$ & $<0.01$ & $<0.01$ & & & & $<0.001$ & $<0.01$ & $<0.01$ \\
\hline NO & & 0.016 & $<0.001$ & 0.02 & & 0.003 & & \\
\hline $\mathrm{NO}_{\mathrm{x}}$ & & & & & & & 0.03 & 0.06 \\
\hline $\mathrm{H}_{2} \mathrm{O}$ & 0.09 & 0.015 & 0.02 & 0.03 & 0.04 & & & \\
\hline
\end{tabular}

${ }^{a}$ Sample container was leak checked with helium prior to opening for loading. Although the sample was loaded in air, some of the helium was still trapped within the rig. Therefore, the initial atmosphere was air/helium.

${ }^{b}$ Sample was loaded in air but was leak checked and backfilled with helium to $1.7 \mathrm{~atm}(10 \mathrm{psig})$ before delivery to HFIR for installation —a HFIR operations requirement that the pressure in the container be greater than the SNF pool pressure. 
Table 3.4. Results of mass spectrometric analysis (vol \%) of gas composition from $\mathrm{UO}_{3} \mathrm{C}_{2} \mathrm{O}$ samples irradiated in either the ${ }^{60} \mathrm{Co}$ source or HFIR SNF elements

\begin{tabular}{|c|c|c|c|c|}
\hline Component & $\begin{array}{c}\mathrm{S}-14 \\
\left(\mathrm{UO}_{3} \mathrm{GH}_{2} \mathrm{O}\right. \\
\text { with } 1.8 \text { wt \% } \\
\left.\mathrm{H}_{2} \mathrm{O}\right)\end{array}$ & $\begin{array}{c}\mathrm{S}-18 \\
\left(\mathrm{UO}_{3} \mathrm{CH}_{2} \mathrm{O} \text { with }\right. \\
2.47 \mathrm{wt} \% \text { sorbed } \\
\left.\mathrm{H}_{2} \mathrm{O}\right)\end{array}$ & $\begin{array}{c}\text { HFIR-4 } \\
\left(\mathrm{UO}_{3} \mathrm{CH}_{2} \mathrm{O}\right)\end{array}$ & $\begin{array}{c}\text { HFIR-6-3 } \\
\left(\mathrm{UO}_{3}\right)\end{array}$ \\
\hline $\begin{array}{c}\text { Initial } \\
\text { atmosphere }\end{array}$ & Air/Heliumª & Air/Helium & Air/Heliumb & Air \\
\hline $\mathrm{N}_{2}$ & 54.8 & 48.35 & 37.34 & 93.94 \\
\hline $\mathrm{He}$ & 33.1 & 34.52 & 51.49 & $<0.01$ \\
\hline $\mathrm{H}_{2}$ & 0.25 & 0.83 & 10.46 & 0.007 \\
\hline $\mathrm{CO}_{2}$ & 2.52 & 3.04 & 0.44 & 1.25 \\
\hline $\mathrm{Ar}$ & 0.63 & 0.56 & 0.24 & 1.14 \\
\hline $\mathrm{O}_{2}$ & 8.47 & 12.47 & 0.0005 & 3.4 \\
\hline $\mathrm{HF} / \mathrm{Ar}^{2+}$ & 0.08 & 0.11 & & $<0.01$ \\
\hline $\mathrm{F}_{2}$ & $<0.01$ & $<0.001$ & & $<0.01$ \\
\hline $\mathrm{CH}_{4}$ & & 0.003 & 0.007 & 0.007 \\
\hline $\mathrm{CF}_{4}$ & $<0.01$ & & & \\
\hline $\mathrm{CO}$ & $<0.01$ & & $<0.01$ & 0.14 \\
\hline NO & 0.12 & 0.07 & & \\
\hline $\mathrm{NO}_{\mathrm{x}}$ & & & & 0.11 \\
\hline $\mathrm{H}_{2} \mathrm{O}$ & 0.02 & 0.04 & 0.02 & \\
\hline
\end{tabular}

${ }^{a}$ Sample container was leak checked with helium prior to opening for loading. Although the sample was loaded in air, some of the helium was still trapped within the rig. Therefore, the starting atmosphere was air/helium.

${ }^{b}$ Sample was loaded in air but was leak checked and backfilled with helium to $1.7 \mathrm{~atm}$ (10 psig) before delivery to HFIR for installation-a HFIR operations requirement that the pressure in the container be greater than the SNF pool pressure. 
Table 3.5. Comparison of gas composition (relative to argon) for a standard air composition and for irradiated $\mathrm{U}_{3} \mathrm{O}_{8}$ samples

\begin{tabular}{ccccccc}
\hline Ratio & Standard air composition $^{a}$ & S-15 & S-19 & HFIR-3 & HFIR-6-1 & HFIR-6-2 \\
\hline $\mathrm{O}_{2}: \mathrm{Ar}$ & 22.47 & 17.33 & 12.34 & 46.50 & 0.007 & 1.35 \\
$\mathrm{CO}_{2}: \mathrm{Ar}$ & 0.03 & 1.07 & 0.42 & 18.00 & 0.36 & 0.27 \\
$\mathrm{~N}_{2}: \mathrm{Ar}$ & 83.98 & 85.26 & 84.83 & 42.50 & 85.62 & 85.31 \\
$\mathrm{H}_{2}: \mathrm{Ar}$ & 0.00005 & 0.018 & 0.016 & 0.40 & 0.043 & 1.29 \\
\hline${ }^{a}$ From CRC Handbook of Chemistry and Physics, 73rded &
\end{tabular}

${ }^{a}$ From CRC Handbook of Chemistry and Physics, 73rd ed., D. R. Lide, ed., CRC Press, Boca Raton, Florida, 1992.

${ }^{b}$ Original sample atmosphere was primarily helium.

Table 3.6. Comparison of gas composition (relative to argon) for a standard air composition and for irradiated $\mathrm{UO}_{3} \bullet x \mathrm{H}_{2} \mathrm{O}$ samples

\begin{tabular}{cccccc}
\hline Ratio & Standard air composition $^{a}$ & $\mathrm{~S}-14$ & $\mathrm{~S}-18$ & HFIR-4 & HFIR-6-3 \\
\hline $\mathrm{O}_{2}: \mathrm{Ar}$ & 22.47 & 13.44 & 22.27 & 0.002 & 2.98 \\
$\mathrm{CO}_{2}: \mathrm{Ar}$ & 0.03 & 4.00 & 5.43 & 1.83 & 1.10 \\
$\mathrm{~N}_{2}: \mathrm{Ar}$ & 83.98 & 86.98 & 86.34 & 1.55 & 82.40 \\
$\mathrm{H}_{2}: \mathrm{Ar}$ & 0.00005 & 0.39 & 1.48 & 43.58 & 0.006 \\
\hline
\end{tabular}

${ }^{a}$ From CRC Handbook of Chemistry and Physics, 73rd ed., D. R. Lide, ed., CRC Press, Boca Raton, Florida, 1992. 
Table 3.7. Results of analysis of samples for U(IV) content

\begin{tabular}{cccc}
\hline & Material & \multicolumn{2}{c}{ Percentage of $\mathrm{U}$ as U(IV) } \\
\cline { 3 - 4 } Experiment & $\mathrm{UO}_{3} \mathrm{CH}_{2} \mathrm{O}$ & $\begin{array}{c}\text { Theoretical for } \\
\text { unirradiated sample }\end{array}$ & After irradiation \\
\hline HFIR-4 & $\mathrm{UO}_{3}$ & 0 & 0 \\
HFIR-6-3 & $\mathrm{U}_{3} \mathrm{O}_{8}$ with $5 \mathrm{wt} \% \mathrm{Gd}_{2} \mathrm{O}_{3}$ \\
and $1.48 \mathrm{wt} \% \mathrm{H}_{2} \mathrm{O}$ & 33.3 & 0 \\
HFIR-6-1 & $\mathrm{U}_{3} \mathrm{O}_{8}$ with $6 \mathrm{wt} \% \mathrm{H}_{2} \mathrm{O}$ & 33.3 & 11.3 \\
\hline
\end{tabular}

\section{DISCUSSION}

\subsection{WATER SORPTION AND DESORPTION}

As stated earlier, it was not practical to study the exact materials in question-namely, the

${ }^{233} \mathrm{U}$ oxides such as those in storage at the ORNL Building 3019 storage facility — due to the high gamma field associated with the ${ }^{232} \mathrm{U}$ impurity. Therefore, it was necessary to obtain surrogate materials (i.e., ${ }^{238} \mathrm{U}$ ) that would closely match those properties anticipated in the actual stored materials and to irradiate these surrogates with high fluxes of gamma radiation to doses that approached those expected in the ${ }^{233} \mathrm{U}$ oxides after years of storage.

The synthesis of these oxides produced material of relatively low surface area that was dry to the extent that could be achieved by the preparative method. After preparation, the oxides were kept in closed containers within a standard dessicator to prevent any extended premature exposure to atmospheric moisture. While more rigorous methods employing inert-atmosphere glove boxes could have been used, it was considered unnecessary due to the limited amount of water that would be encountered during this brief handling. The merit of this decision was corroborated by the actual radiolysis experiments that followed. These showed that the "dry" materials, as produced for this work, showed no pressure increase due to gamma radiolysis.

The design of an experimental plan for studying the radiolysis of moisture associated with the uranium oxides - as the study is related to addressing problems that might be encountered in the practical storage of these oxides - should first consider the quantity of water that might possibly pose a problem. Should it be the first monolayer of adsorbed water, a few percent, or as much water as that produced in saturating the 
sample? With experience from previous work, it was clear that looking at the adsorption and subsequent radiolysis of the very first molecular layers of moisture on these oxides would not produce any measurable radiolytically generated gas pressures. Even though the careful examination of the first few monolayers and their subsequent radiolysis might involve more sophisticated and costly scientific techniques, it would do little to answer the practical questions of storage. A strong indication exists that if radiolytic pressurization were to be a problem, it would be so only at higher moisture contents. Therefore, the more elementary approach of simply adsorbing macro quantities of moisture over a period of time and then examining the radiolysis of these samples was the most direct way to obtain the necessary answers. If loadings of water from a few percent to total saturation of the sample produced no unexpected pressurization of the sample containers or unacceptable hydrogen concentrations, then it would be safe to conclude that the irradiation of the first few molecular layers of moisture on the oxide would be inconsequential.

Additionally, the procedure for studying moisture adsorption rates must be carefully defined. It must be specified whether the bulk sample is: (a) permitted to sit undisturbed in the atmosphere of controlled humidity where only a limited amount of surface is exposed, (b) stirred in the humid atmosphere to exposure fresh surfaces, (c) spread thinly over a large area to expose the maximum quiescent surface, or (d) loaded in a column through which a humidity-controlled carrier gas is passed. Obviously, each of these methods would produce different results, and the establishment of a "standard exposure" would be impossible.

To maximize the exposure rate and to mimic conditions most typical of handling the actual ${ }^{233} \mathrm{U}$ oxides, it was decided that periodic stirring of the particulate oxides in a humid atmosphere ("b" above) most closely reproduced exposures representative of those that might be encountered in storage/handling operations.

Adsorption rates are also most sensitive to the surface area of the adsorbing species. It is possible that some of the stored materials could be of much greater surface area and would, consequently, show much higher rates of adsorption using any of the procedures previously cited. Nevertheless, the surrogate oxides of this report were prepared according to standard procedures similar to those used for the ${ }^{233} \mathrm{U}$ oxides and should, therefore, produce material with similar surface areas. (It was not possible to obtain representative surface area data for the actual stored oxides. However, it was subsequently learned ${ }^{17}$ that the surface area for the stored ${ }^{233} \mathrm{U}_{3} \mathrm{O}_{8}$ ranged from 2 to $>6 \mathrm{~m}^{2} / \mathrm{g}$. While somewhat greater than the $1.34-1.61 \mathrm{~m}^{2} / \mathrm{g}$ found for the material used here, the difference was not considered great enough to produce significantly different results from those reported here.) As it will be shown later, all of these conditions or properties that control moisture loading rates would have little impact on the radiolytic results because the presence of moisture adsorbed on the samples was never found to cause any pressurization problems.

In selecting the relative humidities at which to perform this study, two factors influenced this decision: (1) testing under the worst possible conditions (i.e., those near 100\% relative humidity) and (2) testing under the typical humidity conditions anticipated for East Tennessee, the location of the ORNL storage facility. Lower relative humidities would naturally produce much lower rates and could be examined if the current work 
showed some merit in pursuing such data. The investigation of oxides exposed to moisture from low-humidity atmospheres was not warranted, because no significant effects were seen—even in the more highly loaded samples.

\subsection{1 $\mathrm{UO}_{3}$}

Uranium trioxide is different from the other two oxides considered in this study because it forms a wellcharacterized hydrated compound, customarily written as $\mathrm{UO}_{3} \cdot 2 \mathrm{H}_{2} \mathrm{O}$. The structure of this apparent dihydrate is actually $\mathrm{UO}_{2}(\mathrm{OH})_{2} \bullet \mathrm{H}_{2} \mathrm{O}$, which has only one hydrating molecule attached to a dihydroxy uranyl species. ${ }^{18}$ The anhydrous form (as prepared) is a orange-colored compound; and, when it forms the hydrated species, the orange compound becomes yellow.

Figure 3.1 shows that the very high humidity conditions (97.5\%) produce a rapid rise in moisture content that finally plateaus after about 1 month. The difference in initial rates between the 2- and the 12- $\mathrm{g}$ samples is undoubtedly due to the larger relative (macroscopic) surface area that is exposed in the former. It is not clear why the 2-g sample plateaus at a higher moisture content than the 12-g sample - this result could be just subtle differences in the methods of preparation that have not been fully elucidated.

Figure 3.2 shows the water sorption data for the 12-g sample compared with those for a 4-g sample in $70 \%$ humidity. Again, the smaller sample had a slightly higher initial rate of sorption. As before, this finding probably caused by the larger relative surface area exposed to the atmosphere. The significant observation in $70 \%$ relative humidity is that the moisture content plateaued quickly at $14 \%$, very close to the water content of the hydrated form. It is quite apparent that an equilibrium water vapor pressure for the hydrated form of $\mathrm{UO}_{3}$ exists, below which the hydrate will not form. However, we were not able to measure this value since we did not pursue lower values of the relative humidity.

The TGA results of Fig. 3.4 show an interesting two-step weight loss in flowing argon. The first step comes rather sharply at approximately $100^{\circ} \mathrm{C}$, followed by a more gradual loss between 100 and $400^{\circ} \mathrm{C}$, which is typical of the weight-loss profile for two different forms of water associated on the oxide. The first loss of water (at approximately $100^{\circ} \mathrm{C}$ ) is undoubtedly due to the true hydrated water molecule,

$$
\mathrm{UO}_{2}(\mathrm{OH})_{2} \cdot \mathrm{H}_{2} \mathrm{O} \int \mathrm{UO}_{2}(\mathrm{OH})_{2}+\mathrm{H}_{2} \mathrm{O} 8,
$$

whereas the second loss (between 100 and 400EC) represents the conversion of the dihydroxide form to the simple oxide,

$$
\mathrm{UO}_{2}(\mathrm{OH})_{2} \int \mathrm{UO}_{3}+\mathrm{H}_{2} \mathrm{O} 8 .
$$

These results are consistent with the $\mathrm{UO}_{3}$ production experience that temperatures in excess of $350^{\circ} \mathrm{C}$ are required to produce the anhydrous form. 
Above $400^{\circ} \mathrm{C}$, decomposition of the $\mathrm{UO}_{3}$ to $\mathrm{U}_{3} \mathrm{O}_{8}$ occurs in accordance with the same mechanism used to prepare the $\mathrm{U}_{3} \mathrm{O}_{8}$ material [See Eq. (2)] and is indicated by the slight step at approximately $570^{\circ} \mathrm{C}$. This is not representative of moisture loss from the sample but instead reflects a decomposition of one oxide form to another. The decrease in weight due to the $\mathrm{U}_{3} \mathrm{O}_{8}$ formation, which should be $1.86 \%$, is found to be $1.78 \%$. This result indicates that conversion of $\mathrm{U}_{3} \mathrm{O}_{8}$ is practically complete and that dry $\mathrm{UO}_{3}$ existed after the $400^{\circ} \mathrm{C}$ heat treatment. Therefore, heating $\mathrm{UO}_{3}$ to $650^{\circ} \mathrm{C}$ not only dries it thoroughly but also converts it to $\mathrm{U}_{3} \mathrm{O}_{8}$.

\subsection{2 $\mathrm{U}_{3} \mathrm{O}_{8}$}

The triuranium octaoxide form (a name not commonly used for $\mathrm{U}_{3} \mathrm{O}_{8}$ ) does not adsorb moisture to the extent that uranium trioxide does, nor is it known to form a hydrate. As shown in Fig. 3.3, even after $200 \mathrm{~d}$ of exposure (with intermittent stirring) in a $97.5 \%$ relative humidity condition, the oxide reaches only $8 \%$

moisture content. About one-half of that value is reached under more normal humidity conditions with a relatively uniform rate of adsorption.

Drying this oxide was a simpler physical process, as shown by the drying at $150^{\circ} \mathrm{C}$ (Fig. 3.5) and the DTA/TGA (Fig. 3.6). The major weight loss occurs at $150^{\circ} \mathrm{C}$, followed by no change in weight thereafter. These observations are similar to oven drying operations of a second aliquot from the same $\mathrm{U}_{3} \mathrm{O}_{8}$ batch that had been loaded to $1.6 \%$ moisture content in $97.5 \%$ relative humidity. As noted in the Sect. 3, significant water loss (0.97/1.6) occurred on drying overnight at $120^{\circ} \mathrm{C}$ and all of the adsorbed moisture was removed after holding at $650^{\circ} \mathrm{C}$ for $24 \mathrm{~h}$. (Note the difference between the $150^{\circ} \mathrm{C}$ temperature for the major water removal from $\mathrm{U}_{3} \mathrm{O}_{8}$ and that of $400^{\circ} \mathrm{C}$ for $\mathrm{UO}_{3}$ - which is due, in the latter, to the necessity to decompose the uranyl dihydroxide bonds shown in Eq. [7].) Higher temperatures are unnecessary. Nevertheless, let it be previewed again that the actual gamma radiolysis data in the following section show that removal of this moisture is unnecessary.

\subsection{3. $\mathrm{UO}_{2}$}

Uranium dioxide showed no weight gain on exposure to the humidification apparatus-even at $97.5 \%$ relative humidity. Therefore, the attempt to measure weight loss as a function of heating temperature and time was considered unnecessary. The adsorption of small amounts (e.g., monolayers) of moisture cannot be discounted as a result of this study; it certainly does occur in any normal surface/gas exposure situation.

\footnotetext{
${ }^{*}$ From Table 3.1: $\quad(100 ! 32.6)=67.4 \%$ (dry weight of $\left.\mathrm{UO}_{3}\right)$; $33.8 ! 32.6=1.2 \%\left(\right.$ lost on heating at $\left.650^{\circ} \mathrm{C}\right)$; à $(1.2 / 67.4) \times 100=1.78 \%$.
} 
Because no pressurization was produced from the other oxides that contained only these cursory exposures to moisture, no pressurization is anticipated for such $\mathrm{UO}_{2}$ samples.

Material of higher surface area than that used here (see Table 2.1) would probably adsorb measurable amounts of moisture. However, results from the gamma radiolysis experiments for $\mathrm{U}_{3} \mathrm{O}_{8}$ demonstrated that higher moisture contents will not result in pressurization. It should also be noted that the preparation of $\mathrm{UO}_{2}$ at higher temperatures leads to a sintering of the oxide with accompanying reduction of surface-as shown by comparison of the two $\mathrm{UO}_{2}$ samples in Table 2.1 prepared under different temperature conditions. Nevertheless, for both of these low-surface-area materials, no measurable adsorption of moisture was observed.

\subsection{GAMMA RADIOLYSIS EXPERIMENTS}

\subsection{1 $\mathrm{U}_{3} \mathrm{O}_{8}$}

For the samples with no sorbed moisture (S-7, S-17, and HFIR-2; each loaded in helium), essentially no gases were produced. The small pressure increase to a new steady value seen for these samples (see Figs. 3.8 and 3.10) can be attributed entirely to the heating of the sample during irradiation.

For the samples with sorbed moisture, the overall trend exhibited was the consumption of $\mathrm{O}_{2}$ and the production of small amounts of $\mathrm{CO}_{2}$ and very small amounts of $\mathrm{H}_{2}$. Small amounts of $\mathrm{NO}$ or $\mathrm{NO}_{\mathrm{x}}$ were identified as present. Additionally, an overall pressure decrease was noted in each of these samples upon irradiation. It is clear from examination of Fig. 3.20 that radiation plays a role in the pressure decrease. The pressure decreases during the SNF irradiation and remains steady upon removal of the sample from the SNF element.

The most obvious change for most of the samples with sorbed moisture (with the exception of HFIR-3) was the consumption of $\mathrm{O}_{2}$. (The atmosphere over HFIR-3 was primarily helium, and as a result, the small amount of other gases present may not provide sufficient evidence to draw conclusions regarding an air atmosphere.) Possible sources of $\mathrm{O}_{2}$ consumption include nitrate formation from the radiolysis of moist air, $\mathrm{CO}_{2}$ production, and oxidation of the $\mathrm{U}_{3} \mathrm{O}_{8}$. The following considerations lead us to conclude that all of these play some role during the current irradiations.

The radiolysis of moist air is known to produce nitrogen oxides. ${ }^{19-21}$ The observed pressure decrease could result from the production of nitrogen oxides that subsequently sorb onto the uranium oxide surface. However, the $\mathrm{N}_{2}$ :Ar ratios in Table 3.5 are, with the exception of that for HFIR-3, near the expected value. It is not clear that any of the $\mathrm{N}_{2}$ has been depleted and, although small amounts of $\mathrm{NO}$ or $\mathrm{NO}_{\mathrm{x}}$ were reported 
for these samples, the production of nitrogen oxides appears to play only a small direct role in $\mathrm{O}_{2}$ depletion. Nitrogen oxides may, however, play an indirect role in the $\mathrm{O}_{2}$ depletion through subsequent oxidation of the uranium oxide.

Oxygen could also be consumed through the production of $\mathrm{CO}_{2}$. The $\mathrm{CO}_{2}$ level was elevated in each of the gas samples from the $\mathrm{U}_{3} \mathrm{O}_{8}$ experiments. However, the amount is too small to account for the total amount of $\mathrm{O}_{2}$ that was depleted.

The oxidation of the $\mathrm{U}_{3} \mathrm{O}_{8}$ to higher uranium oxides (i.e., towards $\mathrm{UO}_{3}$ ) could account for $\mathrm{O}_{2}$ depletion as well. Only a small amount of the total uranium ( $<1 \mathrm{wt} \%)$ would need to be oxidized to consume all of the $\mathrm{O}_{2}$ initially present over the sample. This type of mechanism would be self-limiting because a lower pressure limit would be approached as the $\mathrm{O}_{2}$ was depleted - a behavior that is clearly depicted in Figs. 3.13 and 3.14. Radiation-induced oxidation of $\mathrm{UO}_{2}$ has been extensively studied, and refs. 2 and 22 provide a summary of the literature. Many of these studies have focused on the effect of moisture (and, hence, the radiolytic products of water) on the oxidation of $\mathrm{UO}_{2}$ to higher oxides. A number of authors (e.g., Refs. 23-27) have shown that the irradiation of $\mathrm{UO}_{2}$ in the presence of moisture significantly increases the oxidation of $\mathrm{UO}_{2}$ to higher oxides (up to hydrated $\mathrm{UO}_{3}$ ). The presence of nitrogen oxides has also been shown to enhance the oxidation of $\mathrm{UO}_{2} \cdot{ }^{28,29}$

The results of the U(IV) analysis of samples from HFIR-6-1 and HFIR-6-2 (Table 3.7) indicate that some of the uranium in these samples has been oxidized. In both samples, the amount of oxygen consumed does not account for all of the oxidized uranium. These samples both had sorbed moisture present, which could also contribute to the oxidation. In fact, HFIR-6-2, which had about 4 times as much water present as did HFIR-6-1, was significantly more oxidized than the latter.

Figures 3.13 and 3.14 exhibit a small pressure increase upon insertion of the samples into the SNF element. The pressure is then seen to steadily decrease. The initial pressure increase is likely the result of the radiolysis of the water present on the sample (the forward reaction). However, as back reactions occur, the overall pressure decreases as the $\mathrm{O}_{2}$ is consumed.

The radiolysis experiments demonstrate that steady-state limiting pressures are always attained for $\mathrm{U}_{3} \mathrm{O}_{8}$ and that neither large pressures nor unacceptable $\mathrm{H}_{2}$ concentrations are produced. Additionally, the initial moisture content of the sample did not change this outcome, demonstrating that it is not necessary to go to extraordinary means to dry the sample. For samples loaded in an air atmosphere, irradiation resulted in the consumption of $\mathrm{O}_{2}$. The most likely sink for the $\mathrm{O}_{2}$ was in the further oxidation of the $\mathrm{U}_{3} \mathrm{O}_{8}$.

\subsection{2 $\mathrm{UO}_{3}$}

Except for HFIR-4, each of the $\mathrm{UO}_{3} \mathrm{GH}_{2} \mathrm{O}$ samples exhibited a pressure decrease upon irradiation, and small amounts of either $\mathrm{NO}$ or $\mathrm{NO}_{\mathrm{x}}$ were reported. Table 3.6 shows that for most of the samples, the $\mathrm{O}_{2}$ is depleted. The fate of the $\mathrm{O}_{2}$ is not as clear as it was for the $\mathrm{U}_{3} \mathrm{O}_{8}$ samples. Again, small amounts of $\mathrm{NO}$ or 
$\mathrm{NO}_{\mathrm{x}}$ were measured in the gas samples, but the $\mathrm{N}_{2}$ does not appear to be depleted appreciably. The amount of $\mathrm{CO}_{2}$ is significantly higher in each of the samples, which could be a source for some, but not all, of the $\mathrm{O}_{2}$ depletion. Some $\mathrm{O}_{2}$ may have been consumed in corrosion, but no solid evidence exists to make that case.

Unlike the other $\mathrm{UO}_{3}$ samples, sample HFIR-4 exhibited a pressure rise. However, like the others, it ultimately reached a limiting steady-state pressure. The overall pressure rise was about $10 \mathrm{psi}$, and the gas contained about $11 \mathrm{vol} \% \mathrm{H}_{2}$ and no $\mathrm{O}_{2}$. The slope of the linearly increasing portion of Fig. 3.17 can be used to estimate the initial G-value for the $\mathrm{H}_{2}$ production, which is about 0.01 molecules $\mathrm{H}_{2} / 100 \mathrm{eV}$. The source of the $\mathrm{H}_{2}$ may have been the radiolysis of the water of hydration, but this reached a limiting value. Note that the $\mathrm{H}_{2}$ levels were elevated in the ${ }^{60} \mathrm{Co}$-irradiated samples, which had lower total doses than the HFIR-irradiated sample. Additionally, comparison of S-14 with S-18 shows that the sample with more water present produced more $\mathrm{H}_{2}$. Sample HFIR-6-3, which was anhydrous $\mathrm{UO}_{3}$, showed little, if any, $\mathrm{H}_{2}$.

The pressure increase (in the case of HFIR-4) and the production of $\mathrm{H}_{2}$ suggest that the type of water (i.e., hydrate, hydroxide, or adsorbed) may play a role in the radiolytic behavior of this material. As described earlier, the $\mathrm{UO}_{3} \mathrm{C}_{2} \mathrm{H}_{2} \mathrm{O}$ is actually of the form $\mathrm{UO}_{2}(\mathrm{OH})_{2} \mathrm{CH}_{2} \mathrm{O}$. Radiolysis of either the hydroxide or the water of hydration may contribute differently to the radiolytic yield. For $\mathrm{UO}_{3}$, the $\mathrm{H}_{2}$ production appears to be related to the amount of water present and the dose. If it is desirable to eliminate $\mathrm{H}_{2}$ production altogether, then heat treatment $\left(>650^{\circ} \mathrm{C}\right)$ of these materials will result in conversion to $\mathrm{U}_{3} \mathrm{O}_{8}$ [Eq. (2)].

\subsubsection{Summary}

For both $\mathrm{U}_{3} \mathrm{O}_{8}$ and $\mathrm{UO}_{3}$, the studies were carried to doses that produced limiting steady-state pressures-either lower or higher than the atmospheric conditions under which the sample containers were originally loaded. The limiting pressures were most often lower. In a few cases, the limiting pressures rose somewhat above the original loading pressure. However, the samples always reached a limiting pressure. The use of the pressure-estimation equation from the ${ }^{233} \mathrm{U}$ storage standard ${ }^{1}$ would result in the prediction of extremely high pressures for many of the samples that were irradiated. For example, $\mathrm{a}_{2}$ pressure of about 1240 psia would be predicted for HFIR-4 $\left(\mathrm{UO}_{3} \cdot 2 \mathrm{H}_{2} \mathrm{O}\right)$, while a $\mathrm{H}_{2}$ pressure of about 360 psia would be predicted for HFIR-6-2 $\left(\mathrm{U}_{3} \mathrm{O}_{8}\right.$ with $\left.6 \mathrm{wt} \% \mathrm{H}_{2} \mathrm{O}\right)$. When one realizes that sufficient loadings of water existed on some of these samples to cause extremely high pressures within the containers (as predicted by the ${ }^{233} \mathrm{U}$ storage standard) and that the maximum steady-state pressure increase attained was only 10 psi, it should be clear that dominant back reactions are taking place along with the forward radiolytic processes to cause the relatively low pressure limits to be reached.

The $\mathrm{H}_{2}$ yields measured for each of the samples are summarized in Table 4.1. The final total pressure and temperature for each sample is also shown. Samples HFIR-2, HFIR-3, HFIR-4, and HFIR-5 each 


\begin{tabular}{|c|c|c|c|c|c|c|c|c|}
\hline & Container & Material & Dose (rad) & $\begin{array}{l}\text { Initial sample } \\
\text { atmosphere }\end{array}$ & $\begin{array}{c}\text { Final } \\
\text { pressure } \\
\text { (Torr) }\end{array}$ & $\begin{array}{c}\text { Final } \\
\text { temperature } \\
\left({ }^{\circ} \mathrm{C}\right)\end{array}$ & $\begin{array}{c}\text { Vol \% } \\
\mathrm{H}_{2}\end{array}$ & $\begin{array}{l}\text { Estimated } \mathrm{H}_{2} \text { yield } \\
\text { (mmol } \mathrm{H}_{2} / \mathrm{g} \text { sample) }\end{array}$ \\
\hline & S-7 & $\mathrm{U}_{3} \mathrm{O}_{8}$ dry & $1.8 \times 10^{8}$ & $\mathrm{He}$ & $a$ & $a$ & $<0.01$ & 0 \\
\hline & S-15 & $\mathrm{U}_{3} \mathrm{O}_{8}$ with 0.7 wt $\% \mathrm{H}_{2} \mathrm{O}$ & $2.5 \times 10^{8}$ & $\mathrm{Air} / \mathrm{He}$ & 738 & 27 & 0.01 & $9.10 \times 10^{66}$ \\
\hline & S-17 & $\begin{array}{l}\mathrm{U}_{3} \mathrm{O}_{8} \text { dry with } 1.4 \text { wt } \% \\
\text { fluoride }\end{array}$ & $2.2 \times 10^{8}$ & $\mathrm{He}$ & 761 & 28 & 0.02 & $1.50 \times 10^{\mathrm{G}}$ \\
\hline & S-19 & $\mathrm{U}_{3} \mathrm{O}_{8}$ with $0.89 \mathrm{wt} \% \mathrm{H}_{2} \mathrm{O}$ & $2.2 \times 10^{8}$ & $\mathrm{Air} / \mathrm{He}$ & 727 & 28 & 0.01 & $5.07 \times 10^{66}$ \\
\hline & HFIR-2 & $\begin{array}{l}\mathrm{U}_{3} \mathrm{O}_{8} \text { dry with } 1.4 \mathrm{wt} \% \\
\text { fluoride }\end{array}$ & $3.0 \times 10^{10}$ & $\mathrm{He}$ & $1380^{b}$ & 40 & 0.004 & $6.22 \times 10^{66}$ \\
\hline & HFIR-3 & $\begin{array}{l}\mathrm{U}_{3} \mathrm{O}_{8} \text { dry with } 1.4 \mathrm{wt} \% \\
\text { fluoride and } 9.1 \mathrm{wt} \% \mathrm{H}_{2} \mathrm{O}\end{array}$ & $4.5 \times 10^{10}$ & $\mathrm{Air} / \mathrm{He}$ & $1380^{b}$ & 40 & 0.016 & $2.16 \times 10^{\mathrm{G}}$ \\
\hline & HFIR-5 & $\mathrm{U}_{3} \mathrm{O}_{8}$ with $1.04 \mathrm{wt} \% \mathrm{H}_{2} \mathrm{O}$ & $8.2 \times 10^{10}$ & $\mathrm{Air} / \mathrm{He}$ & $1267^{b}$ & 40 & $c$ & $c$ \\
\hline & HFIR-6-1 & $\begin{array}{l}\mathrm{U}_{3} \mathrm{O}_{8} \text { with } 5 \mathrm{wt} \% \mathrm{Gd}_{2} \mathrm{O}_{3} \\
\text { and } 1.48 \mathrm{wt} \% \mathrm{H}_{2} \mathrm{O}\end{array}$ & $3.3 \times 10^{10}$ & Air & 717 & 49.7 & 0.05 & $6.43 \times 10^{\mathrm{G}}$ \\
\hline & HFIR-6-2 & $\mathrm{U}_{3} \mathrm{O}_{8}$ with 6 wt $\% \mathrm{H}_{2} \mathrm{O}$ & $3.2 \times 10^{10}$ & Air & 760 & 49.7 & 1.44 & $1.96 \times 10^{\mathrm{G}}$ \\
\hline \multicolumn{9}{|l|}{$\mathrm{UO}_{3} \cdot x \mathrm{H}_{2} \mathrm{O}$} \\
\hline & S-14 & $\begin{array}{l}\mathrm{UO}_{3} \cdot x \mathrm{H}_{2} \mathrm{O} \text { with } 1.8 \text { wt } \% \\
\mathrm{H}_{2} \mathrm{O}\end{array}$ & $2.5 \times 10^{8}$ & $\mathrm{Air} / \mathrm{He}$ & 718 & 27 & 0.25 & $2.55 \times 10^{G 4}$ \\
\hline & S-18 & $\begin{array}{l}\mathrm{UO}_{3} \cdot 2 \mathrm{H}_{2} \mathrm{O} \text { with } 2.47 \mathrm{wt} \% \\
\text { sorbed } \mathrm{H}_{2} \mathrm{O}\end{array}$ & $2.2 \times 10^{8}$ & $\mathrm{Air} / \mathrm{He}$ & 718 & 28 & 0.83 & $4.34 \times 10^{\mathrm{Gt}}$ \\
\hline & HFIR-4 & $\mathrm{UO}_{3} \cdot 2 \mathrm{H}_{2} \mathrm{O}$ & $3.7 \times 10^{10}$ & $\mathrm{Air} / \mathrm{He}$ & $1742^{b}$ & 40 & 10.6 & $1.99 \times 10^{\mathcal{Q}}$ \\
\hline & HFIR-6-3 & $\mathrm{UO}_{3}$ & $3.3 \times 10^{10}$ & Air & 641 & 49.7 & 0.007 & $5.64 \times 10^{66}$ \\
\hline
\end{tabular}

${ }^{a}$ Sample not instrumented.

${ }^{b}$ Initial sample pressure about 10 psig ( 1280 Torr) at room temperature because of an operational requirement at the HFIR.

${ }^{c}$ Gas sample not taken. 
started at about 10 psig ( 1280 Torr) at room temperature, because of an operational requirement at the HFIR. This requirement then accounts for the higher total pressure observed for these samples. Note that Figs. 3.10-3.12 and Fig. 3.17 show that each of these samples reached low, limiting pressures. The reported yields are for very high doses and are therefore representative of the maximum amount of $\mathrm{H}_{2}$ expected for this material. Again, it should be noted that, for most of the samples, the total $\mathrm{H}_{2}$ yield was very low. Many of the reported yields are near the limit of detection. Three of the "dry" samples had a reported $\mathrm{H}_{2}$ concentration which could have come from the trace amount of water that may have been present on the sample. However, the amount of $\mathrm{H}_{2}$ was at the limit of detection. It is also illustrative to consider the $\mathrm{H}_{2}$ yield in the context of the ${ }^{233} \mathrm{U}$ storage standard, which requires the user to estimate the $\mathrm{H}_{2}$ production as if all available $\mathrm{H}_{2}$ could be released. For example, consider sample HFIR-6-2, which had a 6 wt $\% \mathrm{H}_{2} \mathrm{O}$ content, but only $0.05 \%$ of the total $\mathrm{H}_{2}$ available was released at a high total dose.

One should be careful in arbitrarily applying the yield values to a given storage situation (i.e., multiplying the amount of material in storage by the yield to estimate the $\mathrm{H}_{2}$ production). The high dose experiments clearly demonstrated that equilibrium, in which the forward and back reaction rates are equal, is reached. The back reaction is pressure dependent and, as a result, for larger quantities of material it is understood that the yields (i.e., $\mathrm{mmol}_{2} / \mathrm{g}$ sample) would actually be lower.

While we have not yet been able to define the back-reaction process beyond what is known for the homogeneous gas-phase mechanisms cited in the early literature, ${ }^{30}$ it should be obvious from the results of this work that the consideration of radiolytic degradation of water, other impurities, or the oxides themselves without the full consideration — and appreciation — of the back-reaction mechanisms will lead to erroneous and extreme conclusions regarding the safe storage of these actinide oxides. Consequently, these back-reaction mechanisms have become our focus of study for future work.

\section{CONCLUSIONS}

As stated earlier, it was not practical to study the exact materials in question-namely, the ${ }^{233} \mathrm{U}$ oxides such as those in storage at the ORNL Building 3019 storage facility—due to the high gamma field associated with the ${ }^{232} \mathrm{U}$ impurity. Therefore, it was necessary to obtain surrogate materials that would closely match those properties anticipated in the actual stored materials and to irradiate these surrogates with gamma radiation to doses that approached those expected in the ${ }^{233} \mathrm{U}$ oxides after years of storage.

The synthesis of these oxides produced material of relatively low surface area that was dry to the extent of that achievable by the preparative method. After preparation, the oxides were kept in closed containers within a standard dessicator to prevent any extended premature exposure to atmospheric moisture. While more rigorous methods employing inert-atmosphere glove boxes could have been used, it was considered unnecessary due to the 
limited amount of water that would be encountered during this brief handling. The merit of this decision was corroborated by the actual radiolysis experiments that followed.

These adsorption/desorption results define the extent to which the uranium oxides have a tendency to adsorb moisture from the atmosphere. While adsorption does occur in decreasing amounts as we go from $\mathrm{UO}_{3}$ to $\mathrm{U}_{3} \mathrm{O}_{8}$ to $\mathrm{UO}_{2}$, the removal of this moisture is accomplished at temperatures up to $650^{\circ} \mathrm{C}$. For the uranium oxides in general, $650^{\circ} \mathrm{C}$ is a satisfactory maximum temperature at which to dry.

The gamma radiolysis experiments for uranium oxides exhibited small, if any, pressure increases. Some $\mathrm{H}_{2}$ was produced in the hydrated $\mathrm{UO}_{3}$ samples; however, the $\mathrm{O}_{2}$ from the initial atmosphere over the sample was depleted. This $\mathrm{H}_{2}$ production could be eliminated by the heat treatment at $400^{\circ} \mathrm{C}$ to produce dry $\mathrm{UO}_{3}$ or by the conversion of the $\mathrm{UO}_{3}$ to $\mathrm{U}_{3} \mathrm{O}_{8}$ at $650^{\circ} \mathrm{C}$. For all of the $\mathrm{U}_{3} \mathrm{O}_{8}$ samples loaded in air and irradiated with gamma radiation, a pressure decrease was seen-even for samples with up to 9 wt $\%$ moisture content. Hence, these results demonstrated that efforts to remove all traces of moisture from $\mathrm{U}_{3} \mathrm{O}_{8}$ are not necessary. In fact, the system can tolerate several percent of sorbed moisture - most of which can be easily removed by heating to only $150^{\circ} \mathrm{C}$.

Back-reaction mechanisms that limit the radiolytically generated product gas pressures are clearly evident in this work. Therefore, these reactions require our greatest focus in establishing the overall behavior of actinide oxides in long-term storage situations.

The radiolysis studies that were described in this report used only gamma radiation. Uranium-233, containing the impurity isotope ${ }^{232} \mathrm{U}$, has both gamma and alpha radiation fields associated with it. To provide the complete picture on the radiolytic response of these materials, alpha radiolysis experiments on uranium oxides that have sorbed moisture are being performed at ORNL. 


\section{ACKNOWLEDGMENTS}

The authors would like to acknowledge R. D. Hunt for the performance of the DTA/TGA analyses,

J. L. Marshall for the performance of the mass spectrometric analyses, and the Materials and Chemistry Laboratory, Inc., Oak Ridge, Tennessee, for performance of the Davies-Gray titrations. 



\section{REFERENCES}

1. Criteria for Packaging and Storing Uranium-233-Bearing Materials, DOE-STD-3028-2000, U.S. Department of Energy, Washington, D.C., July 2000.

2. A. S. Icenhour, Radiolytic Effects on Fluoride Impurities in a $U_{3} O_{8}$ Matrix, ORNL/TM-2000/157, UTBattelle, LLC, Oak Ridge National Laboratory, Oak Ridge, Tennessee, May 2000.

3. Handbook of Chemistry and Physics, 41st ed., Chemical Rubber Publishing Co., Cleveland, 1959, p. 2500.

4. J. L. Shepherd and Associates, Manufacturer's data on exposure-rate profile in ORNL ${ }^{60}$ Co source, Glendale, California, December 9, 1977.

5. T. A. Dillow, Oak Ridge National Laboratory, Oak Ridge, Tennessee, personal communication regarding historical exposure-rate measurements for the J. L. Shepherd ${ }^{60}$ Co source to A. S. Icenhour, Oak Ridge National Laboratory, Oak Ridge, Tennessee, April 16, 1998.

6. Standard Practice for Calculating Absorbed Dose from Gamma and X Radiation, ASTM E666-91, American Society for Testing and Materials, Philadelphia, 1991.

7. G. D. Del Cul, A. S. Icenhour, and D. W. Simmons, Prototype Tests for the Recovery and Conversion of $\mathrm{UF}_{6}$ Chemisorbed in NaF Traps for the Molten Salt Reactor Remediation Project, ORNL/TM2000/92, UT-Battelle, LLC, Oak Ridge National Laboratory, Oak Ridge, Tennessee, April 2000.

8. D. F. Williams, G. D. Del Cul, and L. M. Toth, A Descriptive Model of the Molten Salt Reactor Experiment After Shutdown: Review of FY 1995 Progress, ORNL/TM-13142, Oak Ridge National Laboratory, Lockheed Martin Energy Research Corp., Oak Ridge, Tennessee, January 1996.

9. M. W. Kohring, Gamma Flux Measurements on Spent High Flux Isotope Reactor (HFIR) Fuel Assemblies, ORNL/CF-86/256, Martin Marietta Energy Systems, Oak Ridge National Laboratory, Oak Ridge, Tennessee, August 7, 1986.

10. M. W. Kohring, "Spent HFIR Fuel Assembly Dose Rates," Correspondence to R. E. Jones, Oak Ridge National Laboratory, Oak Ridge, Tennessee, September 4, 1987.

11. J. R. Lamarsh, Introduction to Nuclear Reactor Theory, Addison-Wesley Publishing Company, Reading, Massachusetts, 1966.

12. R. W. Hobbs, "Irradiation History for MSRE Experiment Cell 1," Oak Ridge National Laboratory, Oak Ridge, Tennessee, unpublished data, May 1995.

13. L. M. Toth and L. K. Felker, "Fluorine Generation by Gamma Radiolysis of a Fluoride Salt Mixture," Radiat. Eff. Defects Solids 112, 201-210 (1990).

14. W. Davies and W. Gray, "A Rapid and Specific Titrimetric Method for the Precise Determination of Uranium Using Iron (II) Sulfate as Reductant,” Talanta 11, 1203 (1964). 
15. A. R. Eberle and M. W. Lerner, Titrimetric Determination of Total Uranium and Uranium IV in Uranium Dioxide, Progress Report No. 258, New Brunswick Laboratory, New Brunswick, New Jersey, June 1971.

16. R. J. Jarabek, Transport Measurement of $U F_{5}$ Using a Precision Analysis for $U^{+4}$, K/PS-5017, Martin Marietta Energy Systems, Oak Ridge Gaseous Diffusion Plant, Oak Ridge, Tennessee, April 2, 1984.

17. A. M. Krichinsky, Oak Ridge National Laboratory, Oak Ridge, Tennessee, personal communication to A. S. Icenhour, Oak Ridge National Laboratior, Oak Ridge, Tennessee, November 27, 2001.

18. V. Baran, Uranium (VI) - Oxygen Chemistry, Uranyl Hydroxo Complexes, Uranates, and Oxides, Hadronic Press, Inc., Palm Harbor, Florida, 1993.

19. P. Harteck and S. Dondes, "Producing Chemicals with Reactor Radiations," Nucleonics 14(7), 22-25 (1956).

20. W. Primak and L. H. Fuchs, "Nitrogen Fixation in a Nuclear Reactor," Nucleonics 13(2), 38-41 (1955).

21. A. R. Jones, "Radiation-Induced Reactions in the $\mathrm{N}_{2}-\mathrm{O}_{2}-\mathrm{H}_{2} \mathrm{O}$ System," Radiat. Res. 10, 655-663 (1959).

22. R. J. McEachern and P. Taylor, "A Review of the Oxidation of Uranium Dioxide at Temperatures below 400C," J. Nucl. Mater. 254, 87-121 (1998).

23. S. Sunder, D. W. Shoesmith, H. Christensen, N. H. Miller, and M. G. Bailey, "Oxidation of $\mathrm{UO}_{2}$ Fuel by Radicals Formed During Radiolysis of Water,” Mater. Res. Soc. Symp. Proc. 176, 457-464 (1990).

24. S. Sunder and N. H. Miller, "Oxidation of CANDU Uranium Oxide Fuel by Air in Gamma Radiation at 150C," J. Nucl. Mater. 231, 121-131 (1996).

25. K. M. Wasywich, W. H. Hocking, D. W. Shoesmith, and P. Taylor, "Differences in Oxidation Behavior of Used CANDU Fuel During Prolonged Storage in Moisture-Saturated Air and Dry Air at $150^{\circ} \mathrm{C}$," Nucl. Technol. 104, 309-329 (1993).

26. R. E. Einzinger, S. C. Marschman, and H. C. Buchanan, "Spent-Fuel Dry-Bath Oxidation Testing," Nucl. Technol. 94, 383-393 (1991).

27. P. Taylor, D. D. Wood, A. M. Duclos, and D. G. Owen, "Formation of Uranium Trioxide Hydrates on $\mathrm{UO}_{2}$ Fuel in Air-Steam Mixtures Near 200' C, J. Nucl. Mater. 168, $70-75$ (1989).

28. J. S. Anderson, L. E. J. Roberts, and E. A. Harper, "The Oxidation of Uranium Dioxide," J. Chem. Soc. Part IV, 3946-3959 (1955).

29. T. K. Campbell, E. R. Gilbert, G. D. White, G. F. Piepel, and B. J. Wrona, "Oxidation Behavior of Nonirradiated $\mathrm{UO}_{2}$ ", Nucl. Technol. 85, 160-171 (1989).

30. A. O. Allen, C. J. Hochanadel, J. A. Ghormley, and T. W. Davis, "Decomposition of Water and Aqueous Solutions Under Mixed Fast Neutron and Gamma Reactions," J. Phys. Chem. 56, 575 (1952). 


\section{Appendix A: ESTIMATION OF ABSORBED DOSE FROM EXPOSURE}

The exposure rate is reported for both the ${ }^{60} \mathrm{Co}$ source and the HFIR SNF elements that were used in the irradiation experiments. Exposure is a measure of the amount of charge produced in air per unit mass of air. However, in the case of radiolytic experiments, the quantity of interest is the absorbed dose, which is the energy absorbed by a material per unit mass. To compute the absorbed dose, the method presented in ASTM E666-91 is used (Standard Practice for Calculating Absorbed Dose from Gamma and X Radiation, American Society for Testing and Materials, Philadelphia, 1991). The following formula is used to convert exposure rate to dose rate:

$$
\dot{D}_{y}=8.69 \times 10^{-3} \frac{\left(\frac{\mu_{e n}}{\rho}\right)_{y}}{\left(\frac{\mu_{e n}}{\rho}\right)_{a i r}} \dot{X} \exp \left[-\left(\frac{\mu_{e n}}{\rho}\right)_{y} x\right],
$$

where

$$
\begin{array}{lll}
\dot{D}_{y} & =\quad \text { dose rate in material } y \text { at depth } x(\mathrm{~Gy} / \mathrm{h}), \\
\frac{\mu_{e n}}{\rho} \quad=\quad \text { mass energy absorption coefficient }\left(\mathrm{m}^{2} / \mathrm{kg}\right), \text { and } \\
\dot{X} \quad=\quad \text { exposure rate }(\mathrm{R} / \mathrm{h}) .
\end{array}
$$

The value $8.69 \times 10^{-3}$ converts roentgens to grays (Gy) in air.

For small samples, the sample thickness is neglected, and the equation reduces to

$$
\dot{D}_{y}=8.69 \times 10^{-3} \frac{\left(\frac{\mu_{e n}}{\rho}\right)_{y}}{\left(\frac{\mu_{e n}}{\rho}\right)_{a i r}} \dot{X} .
$$


For samples that consist of mixtures of elements, the mass energy absorption coefficient is calculated by Hubbell (Complete citation provided in note to Table A.1):

$$
\frac{\mu_{e n}}{\rho}=\sum_{i} w_{i}\left(\frac{\mu_{e n}}{\rho}\right)_{i}
$$

where

$$
\begin{aligned}
w_{i} & =\text { the proportion by weight of the } i \text { th element (dimensionless), and } \\
\left(\frac{\mu_{e n}}{\rho}\right)_{i} & =\text { mass energy absorption coefficient for the } i \text { th element }\left(\mathrm{m}^{2} / \mathrm{kg}\right)
\end{aligned}
$$

Selected values of $\frac{e n}{\rho}$ for several elements and energies are presented in Table A.1.

To account for the slight attenuation of the photon flux by the irradiation containers, the computed dose rate was multiplied by the attenuation factor $\mathrm{e}^{-: x}$, where : is the attenuation coefficient $\left(\mathrm{cm}^{-1}\right)$ and $x$ is the wall thickness of the container. For the ${ }^{60} \mathrm{Co}$ irradiations, the attenuation factors were calculated based on the average energy of the two emitted gammas (i.e., $1.25 \mathrm{MeV}$ ), while for the HFIR SNF irradiations, the attenuation factor was based on the average energy of $0.93 \mathrm{MeV}$. Selected attenuation coefficients are presented in Table A.2. For the ${ }^{60} \mathrm{Co}$ source, the dose rate, as a function of time after insertion of the sample into the source, is

$$
\dot{D}(t)=\dot{D}_{\circ} e^{-\lambda t}
$$

where

$$
\begin{array}{ll}
\underset{D(t)}{C} & =\text { dose rate at time } t(\mathrm{~Gy} / \mathrm{h}), \\
\underset{D_{\mathrm{B}}}{\mathrm{C}} & =\text { initial dose rate }(\mathrm{Gy} / \mathrm{h}), \\
8 & =\text { decay constant }=\ln 2 / \mathrm{half}^{-l i f e}\left(\mathrm{year}^{-1}\right), \text { and } \\
t & =\text { time since insertion (year). }
\end{array}
$$


The integrated dose at time $t$ is given by integration of Eq. (A.4), resulting in

$$
D(t)=\frac{\dot{D}_{\circ}}{\lambda}\left(1-e^{-\lambda t}\right)
$$

where

$D(t)=$ integrated dose at time $t(\mathrm{~Gy})$.

Table A.1 Selected mass energy absorption coefficients ${ }^{a}$

\begin{tabular}{lccccc}
\hline \multirow{2}{*}{$\begin{array}{c}\text { Energy } \\
(\mathrm{MeV})\end{array}$} & $\mathrm{U}$ & $\mathrm{O}$ & $\mathrm{i}_{\text {en }}{ }^{\prime} \mathrm{D}\left(10^{-3} \mathrm{~m}^{2} / \mathrm{kg}\right)$ & \\
\cline { 2 - 6 } & 4.978 & 2.824 & $\mathrm{~F}$ & $\mathrm{H}_{2} \mathrm{O}$ & air \\
\hline 0.93 & 4.473 & 2.791 & 2.675 & 3.137 & 2.820 \\
1 & 3.748 & 2.669 & 2.528 & 3.100 & 2.787 \\
1.25 & 2.612 & 2.346 & 2.223 & 2.966 & 2.666 \\
2 & & & 2.604 & 2.342 \\
\hline
\end{tabular}

${ }^{a}$ J. H. Hubbell, "Photon Mass Attenuation and Energy-Absorption Coefficients from $1 \mathrm{keV}$ to $20 \mathrm{MeV}$," Int. J. Appl. Radiat. Isot. 33, 1269-90 (1982).

Table A.2 Selected attenuation coefficients $(\mu)$ for materials used in irradiation containers

\begin{tabular}{lcc}
\hline \multirow{2}{*}{$\begin{array}{c}\text { Energy } \\
(\mathrm{MeV})\end{array}$} & \multicolumn{2}{c}{$\mu\left(\mathrm{cm}^{-1}\right)$} \\
\cline { 2 - 3 } $\mathrm{Ni}^{a}$ & $\mathrm{Fe}^{b}$ \\
\hline 0.93 & 0.241 & 0.5004 \\
1 & 0.238 & 0.4807 \\
1.25 & 0.234 & 0.4362 \\
2 & 0.220 & 0.3421 \\
\hline
\end{tabular}

${ }^{a}$ E. Storm and H. I. Israel, Nuclear Data Tables A7, 565 (1970).

${ }^{b}$ J. H. Hubbell, "Photon Mass Attenuation and EnergyAbsorption Coefficients from $1 \mathrm{keV}$ to $20 \mathrm{MeV}$," Int. J. Appl. Radiat. Isot. 33, 1269-1290 (1982). 
For the HFIR SNF element irradiations, exposure-rate data, as a function of time, were provided. These data were fit to curves (e.g., Fig. A.1), which were integrated to determine the total exposure during an irradiation. This exposure was then converted to dose by using Eqs. (A.2) and (A.3). The attenuation of the gamma field by the walls of the sample container was accounted for by multiplying the computed dose by the attenuation factor, $\mathrm{e}^{-\mu \mathrm{x}}$.

The HFIR SNF element emits a spectrum of gamma-ray energies. Based on work by D. F. Williams, G. D. Del Cul, and L. M. Toth (A Descriptive Model of the Molten Salt Reactor Experiment After Shutdown: Review of FY 1995 Progress, ORNL/TM-13142, Lockheed Martin Energy Research Corp., Oak Ridge National Laboratory, Oak Ridge, Tennessee, January 1996), the average gamma energy (1 d after SNF discharge from the reactor) is $0.93 \mathrm{MeV}$ (see Table 2.4 in the body of this report) Attenuation factors (and hence, dose) are calculated based on this energy. Additional calculations were performed using different energies for the gamma rays: 1 and $2 \mathrm{MeV}$. In each case, the computed G-value for the gas yield was the same; hence, the G-value computation was relatively insensitive to the gamma energy for the HFIR SNF irradiations. 
ORNL DWG 2000-04282

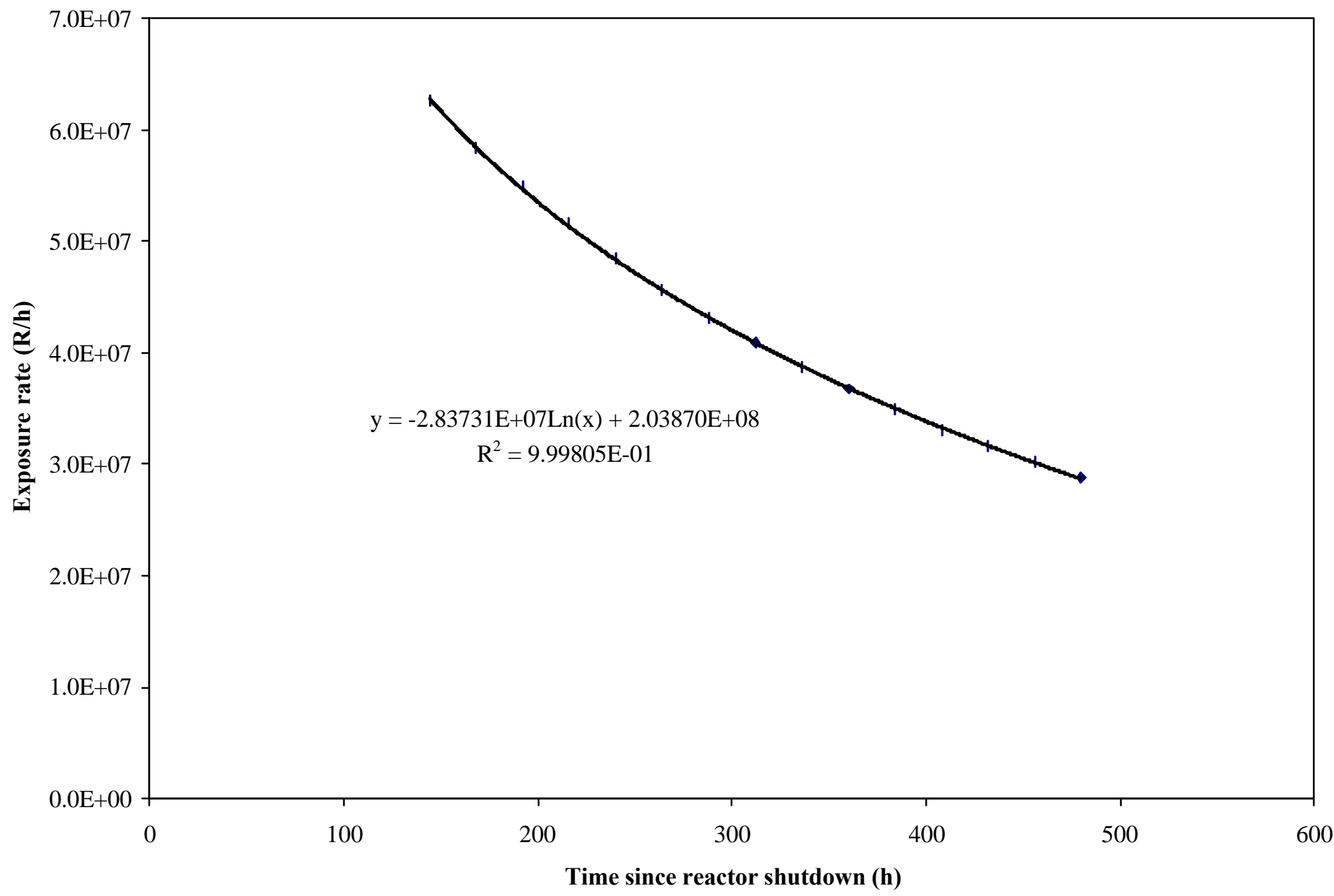

Fig. A.1. Exposure-rate-curve fit for HFIR SNF element from cycle 371. 
ORNL/TM-2001/59

\section{INTERNAL DISTRIBUTION}

\author{
1. J. M. Begovich \\ 2. P. J. Bereolos \\ 3. W. D. Bond \\ 4. R. A. Bond \\ 5. T. B. Conley \\ 6. G. D. Del Cul \\ 7. R. L. Faulkner \\ 8. D. Foster \\ 9. J. N. Herndon \\ 10-15. A. S. Icenhour \\ 16. L. N. Klatt \\ 17. A. M. Krichinsky
}

\author{
18. H. Luo \\ 19. P. E. Osborne \\ 20. F. J. Peretz \\ 21. J. E. Rushton \\ 22. D. W. Simmons \\ 23-27. L. M. Toth \\ 28. L. D. Trowbridge \\ 29. R. M. Wham \\ 30. D. F. Williams \\ 31. Central Research Library \\ 32. ORNL OTIC-RC \\ 33. NSTD DMC
}

\section{EXTERNAL DISTRIBUTION}

34. N. M. Askew, U. S. Department of Energy, Savannah River Site Operations Office, WSRC, Bldg. 703F, Road 1A, Aiken, SC 29801

35. L. F. Blankner, U. S. Department of Energy, Oak Ridge Operations Office, Oak Ridge National Laboratory, P.O. Box 2008 MS-6269, Oak Ridge, TN 37831-6269

36. H. E. Clark, U. S. Department of Energy, Oak Ridge National Laboratory, P.O. Box 2008 MS-6269, Oak Ridge, TN 37831-6269

37. C. H. Delegard, Pacific Northwest National Laboratory, 902 Battelle Blvd., PO Box 999, MS P7-25, Richland, WA 99352

38. P. G. Eller, U. S. Department of Energy, Los Alamos National Laboratory, MS-E505, NMT-11, P.O. Box 1663, Los Alamos, NM 87545

39. H. C. Johnson, U. S. Department of Energy, Headquarters, EM-21, Forrestal, 1000 Independence Ave. S.W., Washington, D.C. 20585

40. R. Lehman, U. S. Department of Energy, Headquarters, SC-81, GTN, 19901 Germantown Rd., Germantown, MD 20874-1290

41. R. R. Livingston, U. S. Department of Energy, Savannah River Site Operations Office, WSRC, Bldg. 773-A, Road 1A, Aiken, SC 29801

42. R. E. Mason, U. S. Department of Energy, Los Alamos National Laboratory, MS J565, C-SIC, Los Alamos, NM, 87545

43. L. Morales, U. S. Department of Energy, Los Alamos National Laboratory, MS J565, C-SIC, Los Alamos, NM, 87545

44. M. T. Paffett, U. S. Department of Energy, Los Alamos National Laboratory, MS J565, C-SIC, Los Alamos, NM, 87545

45. G. D. Roberson, U. S. Department of Energy, Albuquerque Operations Office, Bldg. 382-2, AL, Pennsylvania and H Street, Kirkland Air Force Base, Albuquerque, NM 87116

46. J. Schaade, Savannah River Site Operations Office, WSRD, Bldg. 704-F, Road 1A, Aiken, SC 29801

47. J. C. Tseng, U. S. Department of Energy, Headquarters, GTN, 19901 Germantown Rd., Germantown, MD 20874-1290

48. L. A. Worl, U. S. Department of Energy, Los Alamos National Laboratory, NMT-11, MSE505, Los Alamos, NM 87545 